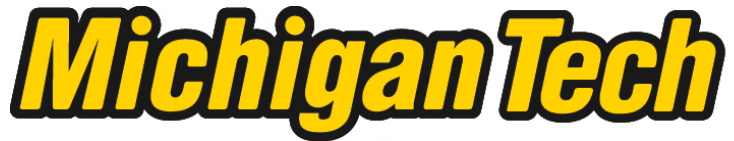 \\ Michigan Technological University Create the Future Digital Commons @ Michigan Tech
}

\section{The spatial distribution of Copernicia alba (Morong) in the district of Bahia Negra, Paraguay}

Michelle E. Cisz

Michigan Technological University

Follow this and additional works at: https://digitalcommons.mtu.edu/etds

Part of the Forest Sciences Commons

Copyright 2011 Michelle E. Cisz

\section{Recommended Citation}

Cisz, Michelle E., "The spatial distribution of Copernicia alba (Morong) in the district of Bahia Negra, Paraguay", Master's Thesis, Michigan Technological University, 2011.

https://doi.org/10.37099/mtu.dc.etds/152

Follow this and additional works at: https://digitalcommons.mtu.edu/etds

8 Part of the Forest Sciences Commons 


\title{
THE SPATIAL DISTRIBUTION OF COPERNICIA ALBA (MORONG) IN THE DISTRICT OF BAHIA NEGRA, PARAGUAY
}

\author{
By
}

Michelle E. Cisz

\begin{abstract}
A THESIS
Submitted in partial fulfillment of the requirements for the degree of MASTER OF SCIENCE

(Forestry)
\end{abstract}

MICHIGAN TECHNOLOGICAL UNIVERSITY

2011

(C) Michelle E. Cisz 2011 
This thesis, "The Spatial Distribution of Copernicia alba (Morong.) in the District of Bahía Negra, Paraguay," is hereby approved in partial fulfillment of the requirement for the Degree of MASTER OF SCIENCE IN FORESTRY

School of Forest Resources and Environmental Science

Signatures:

Thesis Advisor

Dr. Blair D. Orr

Dean

Dr. Margaret R. Gale

Date 


\section{Dedication}

I would like to dedicate this thesis to those who had supported me the most over the past four years. I would like to thank my family for their unconditional love and support and Blair Orr, who as an advisor, goes above and beyond the call of duty. Both abroad and upon return, his active support speaks to his belief in a program for volunteers making the most of their experience abroad. Lastly, I would like to dedicate this work to the kids and young adults of Bahía Negra that I had the pleasure to spend time with. My wishes are with those who will continue to participate actively in the community and care for the natural environment which they know more intimately than most. As in many parts of Paraguay, Bahía Negra overflows with a full guampa of yerba, a smile, and good old fashioned hospitality

Para la comunidad de Babia Negra. Donde la yvytu oipeju piro ho'ysa hasy norte hatã. 


\section{Table Of Contents}

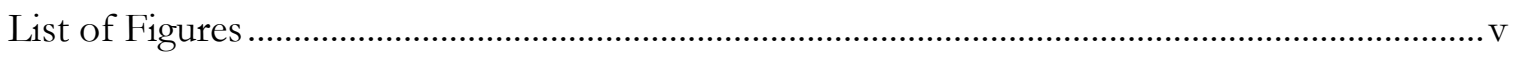

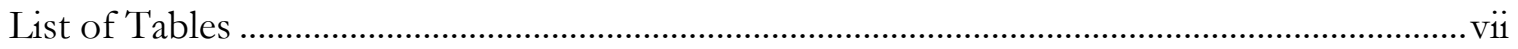

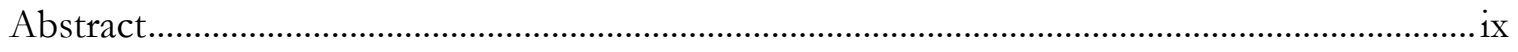

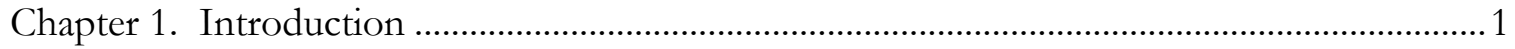

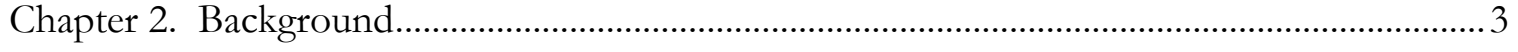

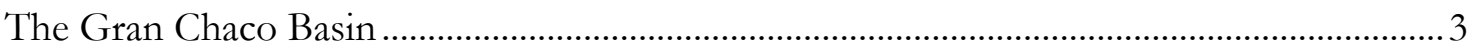

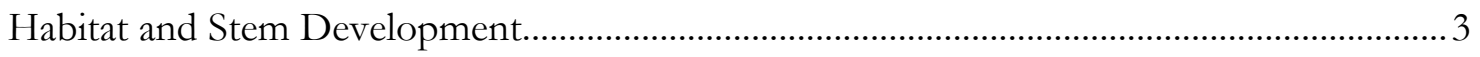

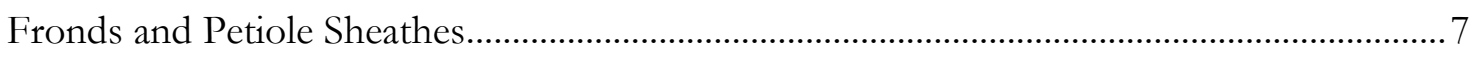

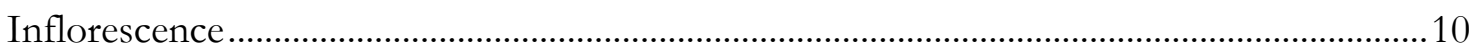

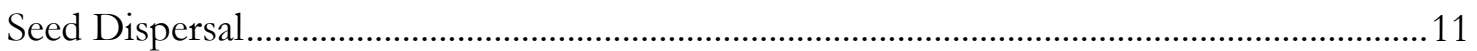

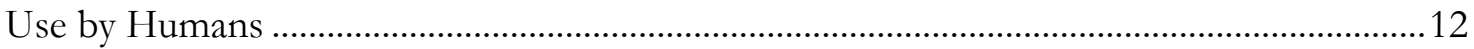

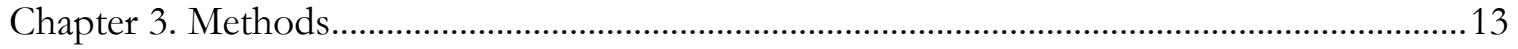

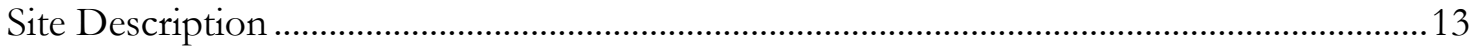

Site Selection \& Data Collection ...........................................................................................17

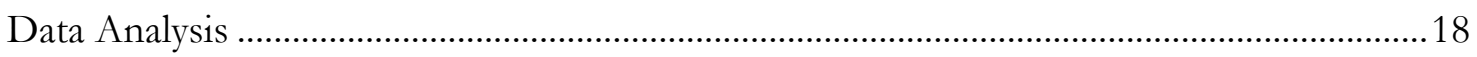

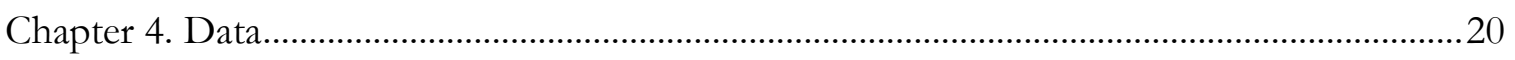

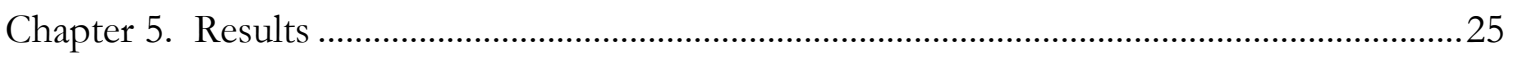

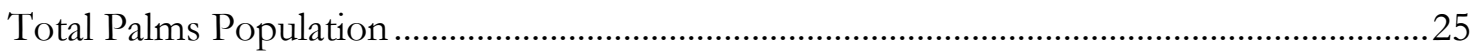

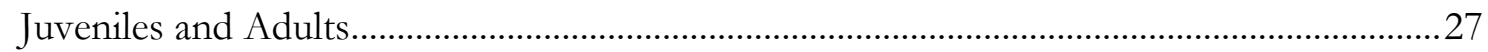

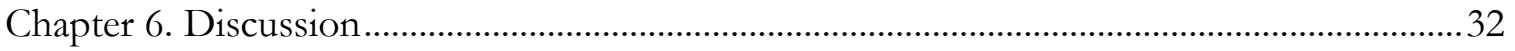

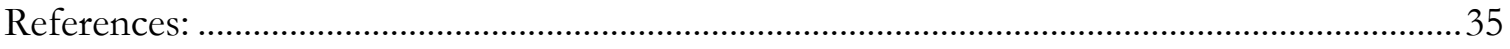

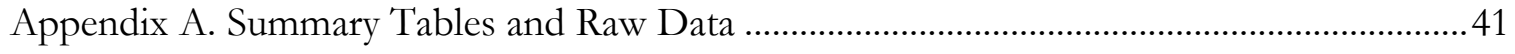

Appendix B. Diggles F tests for Plots 1-6 for Total Palms Population.....................................64

Appendix C. Spatial Symbol Diagrams with juveniles and adults for all 6 plots ...................... 70

Appendix D. Diameter Distributions for each of the 6 plots. ....................................................73

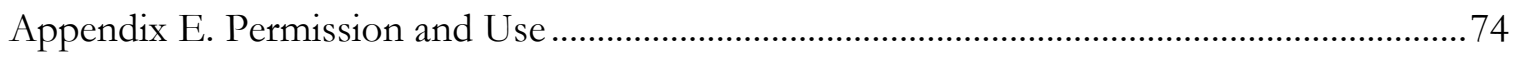




\section{List of Figures}

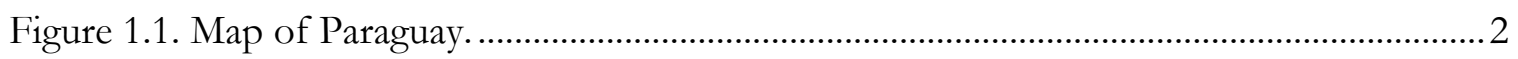

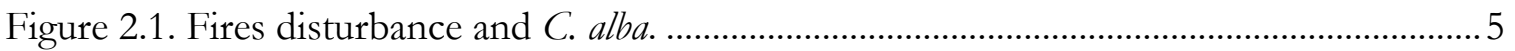

Figure 2.2. Palms adaptation to flooding: adventitious roots...................................................... 6

Figure 2.3. Characteristic "skirt" shape from Plot 5 ..................................................................... 8

Figure 2.4. Palms adapttion to fire: waxy, bifid leaves .............................................................. 8

Figure 2.5 Inflorescence and frond petioles from Plot 5 ........................................................... 9

Figure 2.6. Budding trimeric flowers from November, 2010, Plot 5.......................................10

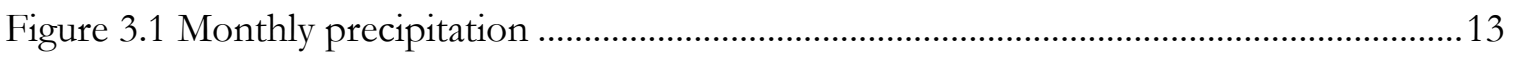

Figure 3.2. Map of study plots of the Biological Reserve, Tres Gigantes. ...................................15

Figure 3.3. Juvenile palms in understory codominated with grasses, and regenerating

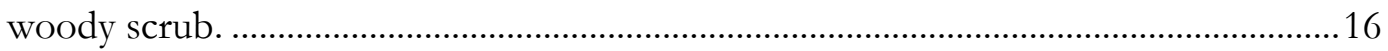

Figure 3.4. Woody scrub patch of Fabacea spp 30 meters north of Plot 3................................16

Figure 4.1. Histogram count of juveniles and adults in each 6 plots.........................................20

Figure 4.2. The height structure of palms in each plot occupying the under, mid, and

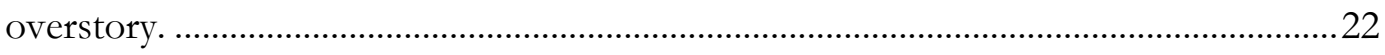

Figures 4.3 and Figure 4.4. Stand succession in Plots 4, 5, and 6 ..........................................24

Figure 5.1 Ripley's K test for total palm populations, Plots 1-6. Total populations display both random and clustered patterns with the exception of Plots 3 and 4........

Figure 5.2 Ripley's K test for randomness in adult (left column) and juvenile

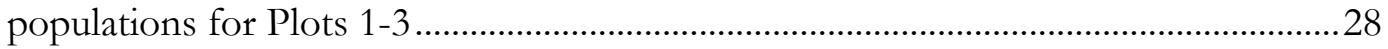

Figure 5.3 Ripley's K test for randomness in adult and juvenile populations for Plots

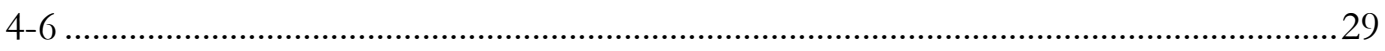

Figure 5.4: Symbol diagram showing juvenile and adult clustering in Plot 2.......................... 31

Figure 6.1 Juvenile mortality six months after the 2009 fire........................................................34

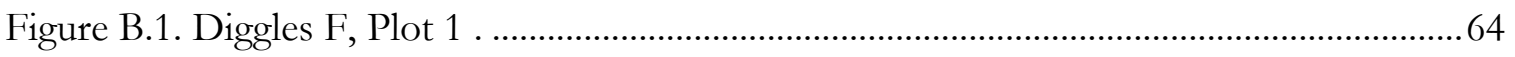

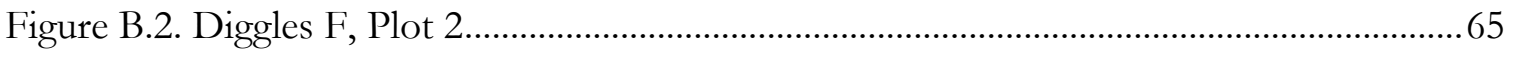

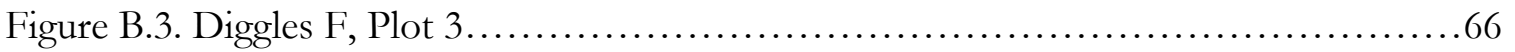

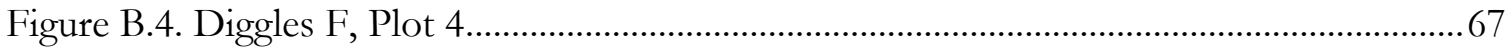

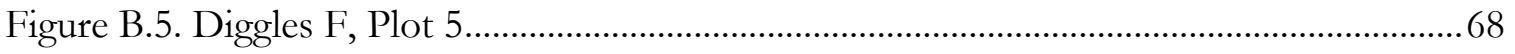

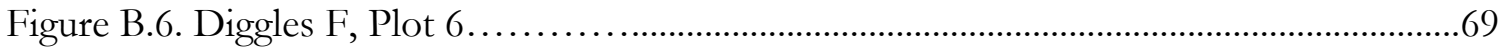

Figure C.1. Symbol diagram, juveniles and adults, Plot 1 ......................................................... 70 
Figure C.2. Symbol diagram, juveniles and adults, Plot 3........................................................ 70

Figure C.3. Symbol diagram, juveniles and adults, Plot 4. ......................................................... 71

Figure C.4. Symbol diagram, juveniles and adults, Plot 5 .......................................................... 71

Figure C.5. Symbol diagram, juveniles and adults, Plot 6 ......................................................... 72

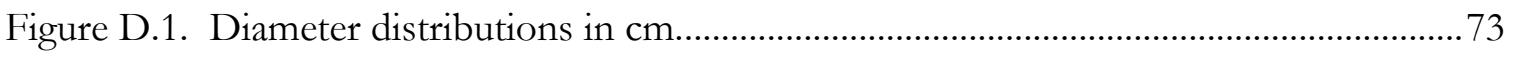




\section{List of Tables}

Table 4.1 Summary of total palm population...............................21

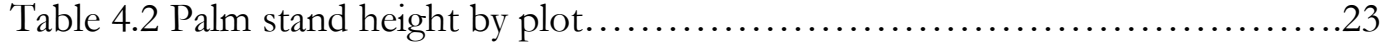




\section{Acknowledgements}

This thesis could not be possible without the continued support and advice of Blair Orr. I would also like to thank Professor Rosa Degen of the University of Asunción (UNA), Secretaría del Ambiente (SEAM), and the Eco-Pantanal Youth Group for their support in my adventures. I would also like to thank Peace Corps Paraguay for their networking support, their help in assuring the safety of volunteers who helped out in this study, and lastly giving me the opportunity to live as a volunteer in the quiet, isolated paradise Bahía Negra.

Acknowledgements are not complete without mention of the Conservation Nonprofit organization, Guyra Paraguay. Their help was essential in directing me to local resources and people who facilitated the research at 3 Giants Reserve (Tres Gigantes). This is not exhaustive. There are still many others who have helped along the way in various means of support. My gratitude is equally measurable in good faith that they know who they are. 


\begin{abstract}
$\underline{\text { Abstract }}$
The Humid Chaco of Northeast Paraguay harbors monoculture palm savannas in which Copernicia alba is the only dominant overstory species. The study's objective was to provide the complete spatial distribution of a simple ecosystem lacking confounding factors of overstory competition and changes in slope. Palms within six, 50 x 50m plots were marked by their GPS location and measured for dbh and total stem height. The spatial distribution was individually analyzed for each plot at the local scale up to $12 \mathrm{~m}$ using Ripley's K test. For the total population including juvenile and adult plants, the sample plots contained both random and clustered distribution patterns. In each of the six plots, the juvenile populations exhibited more clustered patterns than the adult population of each plot.
\end{abstract}

Keywords: Chaco, savannah, palmares, local scale, conspecific population dynamics 


\section{Chapter 1. Introduction}

The complete spatial patterns of a plant species can describe the interactions between the plant and its environment and indicate something about conspecific population dynamics. Scale is an important element in considering the patterns of a plant species. Climate, disturbances such as fire and flood, plant community associations, and geomorphic processes are key physical characteristics of this savanna ecosystem that could drive patterns of a plant population at both the landscape and regional scales. In comparison, the local scale also gives insights to specific mechanisms of that particular species (Gillson 2003, Caylor 2006) Palms in open savanna ecosystems of Africa have been found clustered as juveniles and adults less clustered (Barot et al. 1999). Other palm distribution studies in ecosystems with less vegetative food resources have found seed predation as a driving factor for palm patterns. (Wehncke et al. 2009). Differences could depend upon both physiological difference particular to that palm species such as root systems and fruit size, and also on underlying characteristics of environment.

The purpose of this study was to assess the local spatial distribution of the palm, Copernicia alba (Morong.), as an overstory dominant species within the savanna, occupying the outskirts of a lowland, alluvial plain. The hypothesis was that C.alba is randomly distributed. In addition to the total palm population being analyzed individually per plot, palms were divided into juvenile and adult classes for post hoc statistical analysis. While total populations varied between random and slightly clustered patterns, juvenile populations were consistently found more clustered than the adult populations in each of the six plots. 


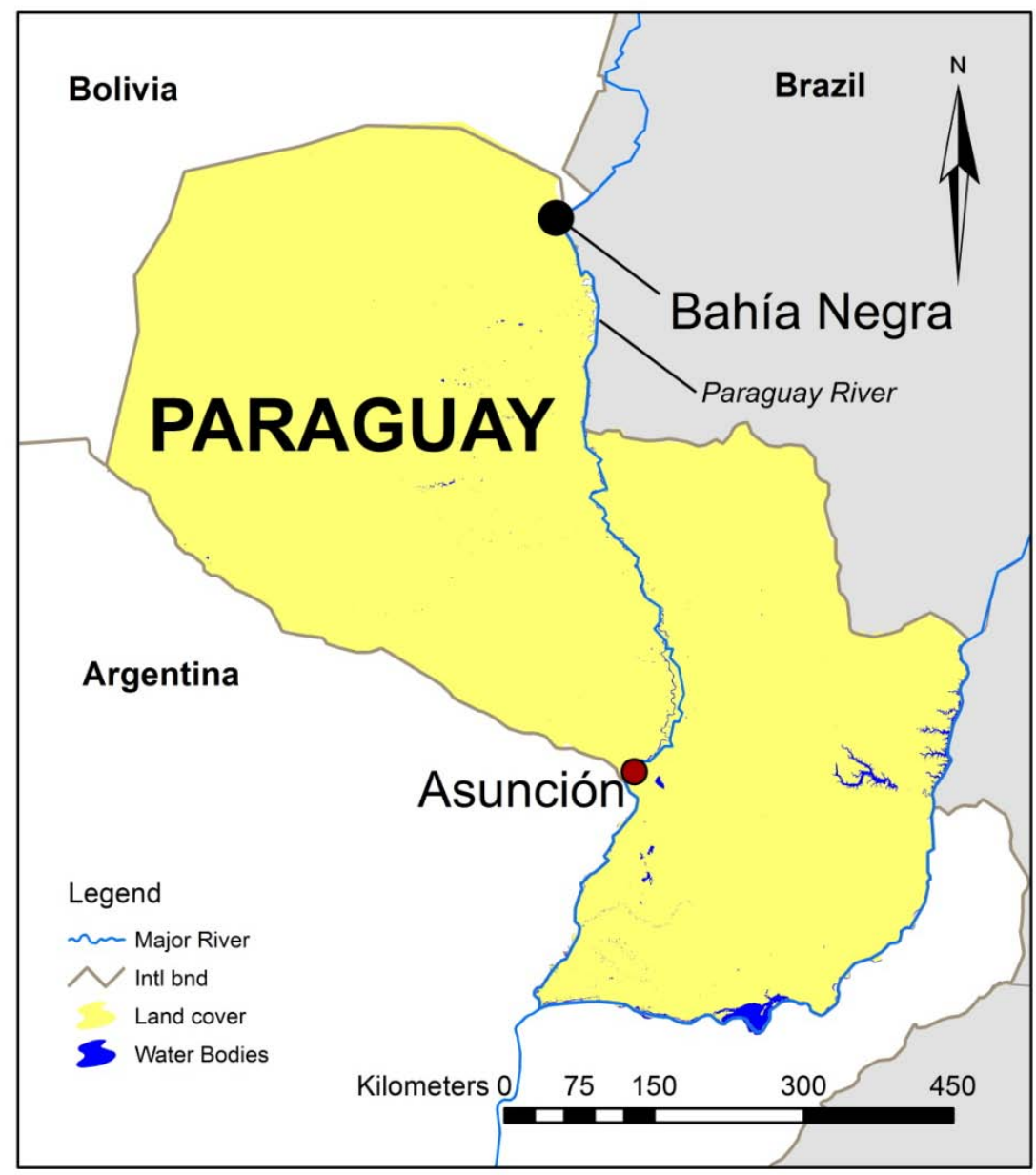

Figure 1.1. Map of Paraguay by Michelle Cisz (Data source FAO 2009).

Since the study was conducted at the local scale of less than $12 \mathrm{~m}$, Chapter 2 (Background) briefly describes $C$. alba's physical attributes, the natural behavior in seed and flower production, and aspects of its development growth, based upon the available literature and observations from the field. Chapter 3 (Methods) covers field data collection and statistical analysis. Chapter 4 (Data) contains demographic summaries of six plots in monoculture stands. Chapter 5 (Results and Discussion) presents the spatial patterns for the entire palm populations greater than $1 \mathrm{~m}$ for each plot. In addition to the total palm populations, spatial distributions of juveniles and adults were also analyzed for each plot. Discussions of what processes could be influencing the clustered juveniles, and less clustered adults are discussed as they relate to both intrinsic and extrinsic mechanisms of $C$. alba populations at the local scale. 


\section{Chapter 2. Background}

The sections "The Gran Chaco Basin" and "Habitat and Stem Development" provide a brief overview of $C$. alba's natural habitat in Northern Paraguay. Since the study assesses the palm at a local scale, the subsequent sections of this chapter (Fronds and Petiole Sheathes, Inflorescence, and Seed Dispersal) focus on the physical and behavioral characteristics of C. alba.

\section{The Gran Chaco Basin}

The Chaco is part of a great river basin south of the Amazon. The Chaco extends across Argentina, Paraguay, and Bolivia, and is approximately 1,000,000 $\mathrm{km}^{2}$ in size. Fire is a historically common disturbance agent to the dry and humid Chaco as well as the neighboring Pantanal wetlands in Brazil (Bravo et al. 2008). Northern Paraguay supports diverse vegetation types including, but not limited to thorny scrub forests, wetlands, and grasslands. The bedrock is covered by a thick layer of fine grained sediment. As part of a lowland floodplain created in the Pleistocene Epoch, the Paraguay River supports a broken landscape of monoculture palm forests and riparian edges rich in species characteristic of the Brazilian Amazon and cerrado (Hay 1993; Iriondo 1993; Gardner et al. 1995; Oliveeira et al. 2002; Renshaw 2002).

\section{Habitat and Stem Development}

Copernicia alba (Morong.) has been documented from latitudes $14^{\circ} \mathrm{S}$ to $27^{\circ} \mathrm{S}$ and longitudes $56^{\circ} 3^{\prime} \mathrm{W}$ to $66^{\circ} \mathrm{W}$, along the Pilcomayo and Paraguay Rivers. Mature palms occupy the overstory in both forest and grassland habitats. Within forests, they codominate the overstory as adults and can be found occupying midstories. Throughout the Chaco they are associated with flat alluvial flood zones that cycle between floods and long periods of drought (Moraes 1991; Degen 1998; Mereles 2001; Yamashita \& Barros 2003, Vogt and Mereles 2005).

A member of the Arecaceae family, C. alba was first officially documented by Thomas Morong during the two years he spent in Paraguay from 1888 to 1890 (Britton 
1894). Three species were originally described by Morong: Copernicia blanca (white palm), Copernicia roja (red palm), and Copernicia negra (black palm). They are now considered the same species, but of different developmental stages (Valente 1957; Michalowski 1958; Moraes 1991; Mereles 2001). The palm's common name is Caranday or in Guarani, Karanda'y, meaning "water palm”.

Young palms can appear bristly with scaled petiole fronds attached. With age and growth in height, the petiole leaves are shed and the stem (trunk) can appear in various shades of light gray. This is the "white palm" where the xylem is pliable and less dense. The meristem fibers become denser and increase in lignin content as the palm develops from white to brown (referred to as "red palm" in spanish), and eventually to black (Valente 1957). C. alba is resistant to most fires in the savannas, which can spread quickly by wind and are of light intensity. Occasionally, palms were found within the study site with deep meristem burns (Figure 2.1). The vascular meristem is also well adapted to floods and grows primary and secondary adventitious roots to help support the palm while maintaining root aeration (Figure 2.2). 


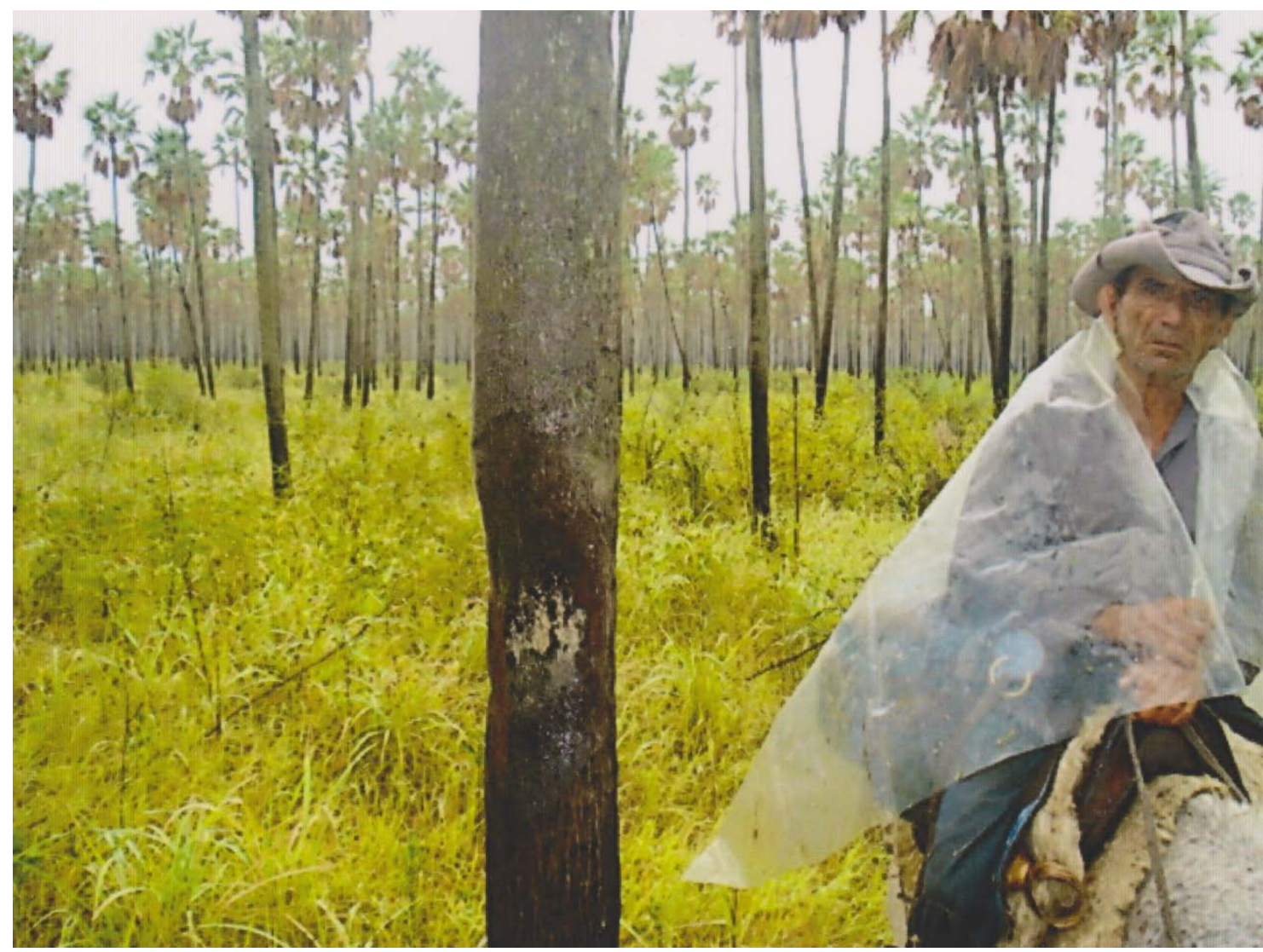

Figure 2.1. Fires are generally fast and of light intensity although palm trees can be found on occasion with deep vascular meristem burns. 


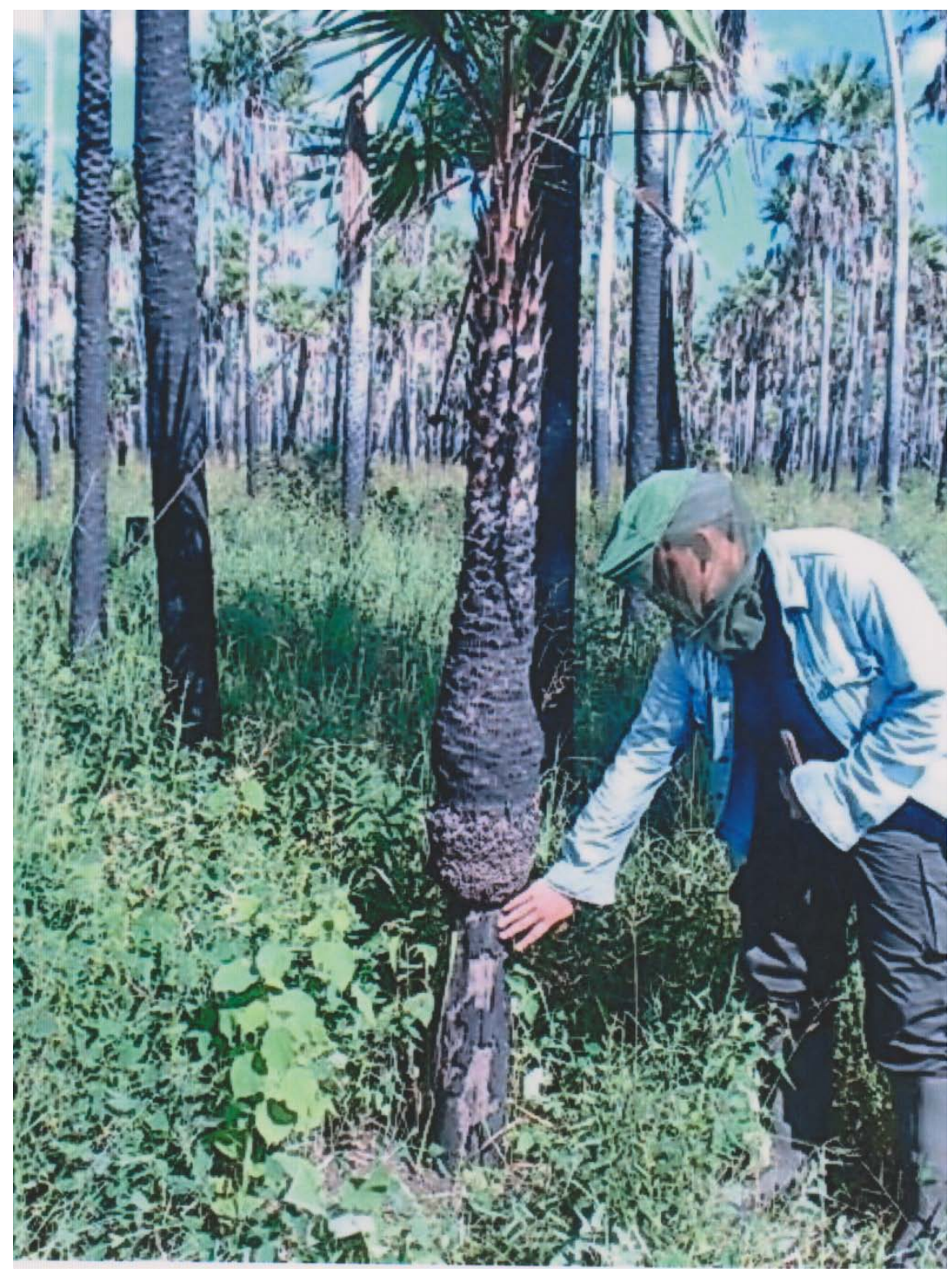

Figure 2.2. Palms adaptation to flooding within the gallery forests result in primary and secondary adventitious root structures. 


\section{Fronds and Petiole Sheathes}

C. alba is 10 to 13 meters tall, with some specimen heights reaching $25 \mathrm{~m}$. Their dbhs can range from 10 to $30 \mathrm{~cm}$ (Valente 1957; Neiff 2001), with the widest palms having $40 \mathrm{~cm}$ diameters (Dahlgren \& Glassman 1963; López et al. 1987; and Neiff 2001).

After C. alba's energy is invested into developing a crown of spiral fronds, the palms invest energy resources into height growth. Since they are monocots, the palms do not undergo secondary growth as dicotyledonous trees do. New fronds grow from the terminal apex of the stem, adding height through the development of the vascular meristem. With the new added growth, older rachises that appear lower on the stem eventually detach. In doing so, they form a "skirt" at the base of the crown (Figure 2.3). The frond rachises themselves normally vary in length from 0.5 to $0.7 \mathrm{~m}$, having a maximum length of 1.5 m (López et al. 1987; Noblick et al. 1992; Degen 1998; Neiff 2001; Peña-Chocarro et al. 2006). Before complete detachment, the fronds droop down forming the bottom "skirt" of the crown (Figure 2.3). When leaf shoots are new, they are yellowish green. They mature to a darker green, retaining a waxy luster to the ventral side (Figure 2.4). Leaves at the bottom of the skirt are similar in color to leaves on the ground; often pale shades of yellow, to light tan, or gray. 


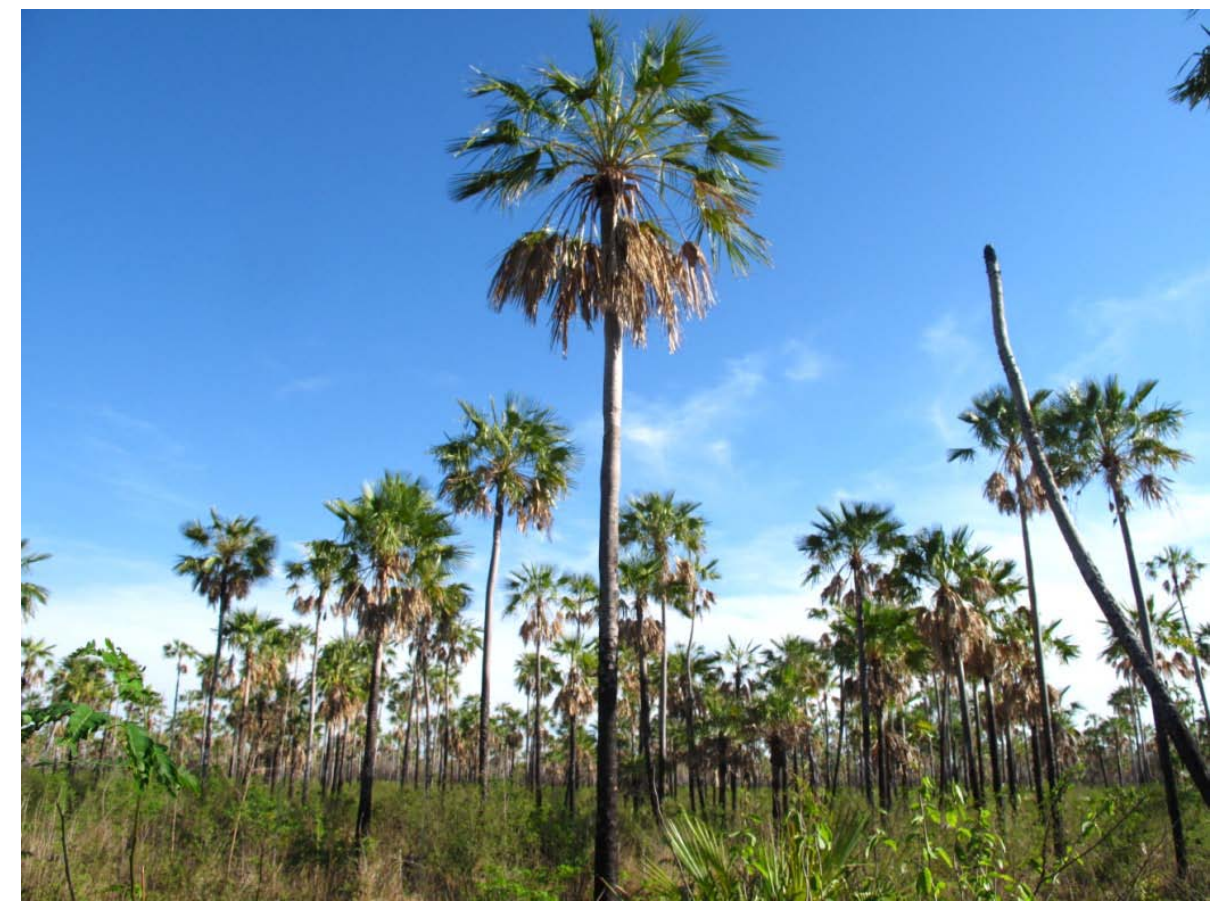

Figure 2.3. Characteristic "skirt" shape on Plot 5 (Photo by Joan Ngo).

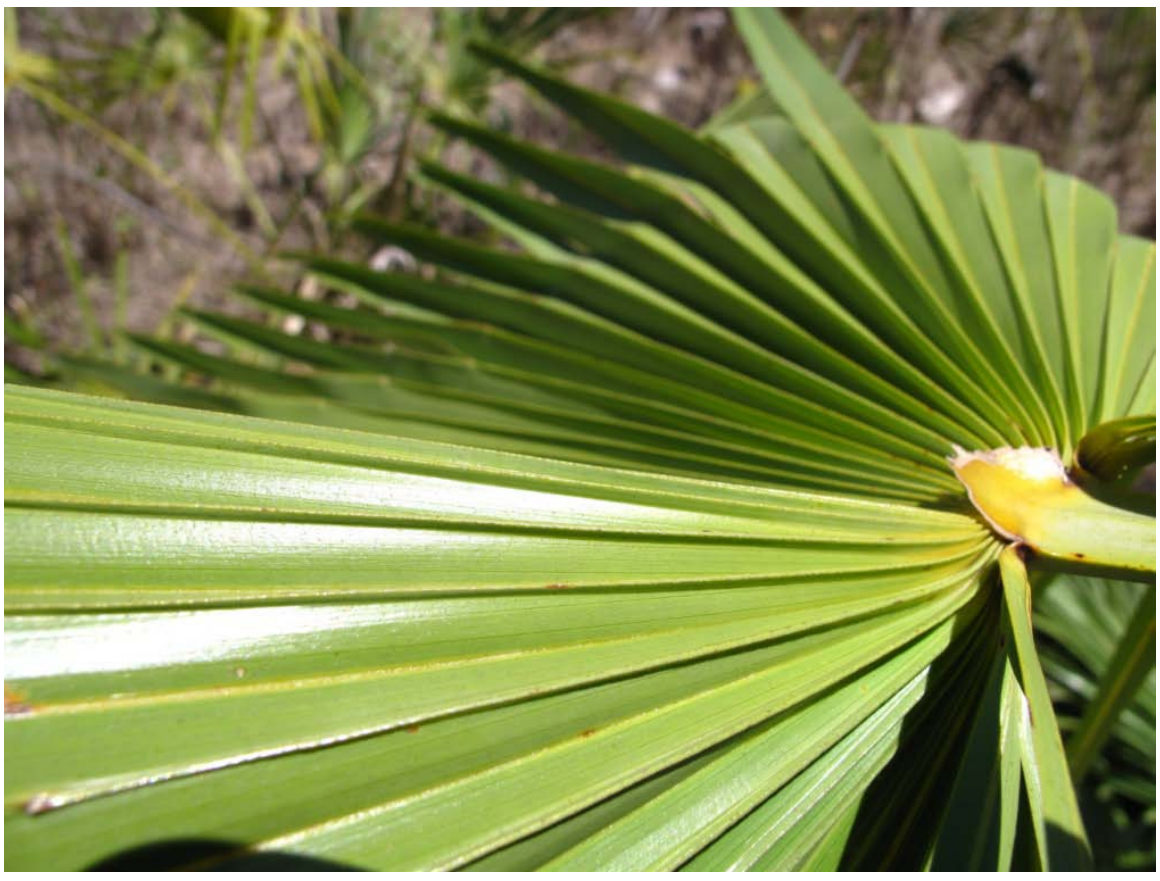

Figure 2.4. Waxy, bifid leaves of $C$. alba join at the rigid hastula only present on one side of the leaf (Photo Courtesy of Joan Ngo). 
After a frond falls off, it leaves behind a reduced bract or leaf scars, giving the palm stem a scaled appearance. As C. alba ages, generally these scales are lost (PeñaChocarro et al. 2006). Fronds that make up the crown are secured to the trunk or stem apex by a fibrous interwoven sheath called the cirrus (Figure 2.5)

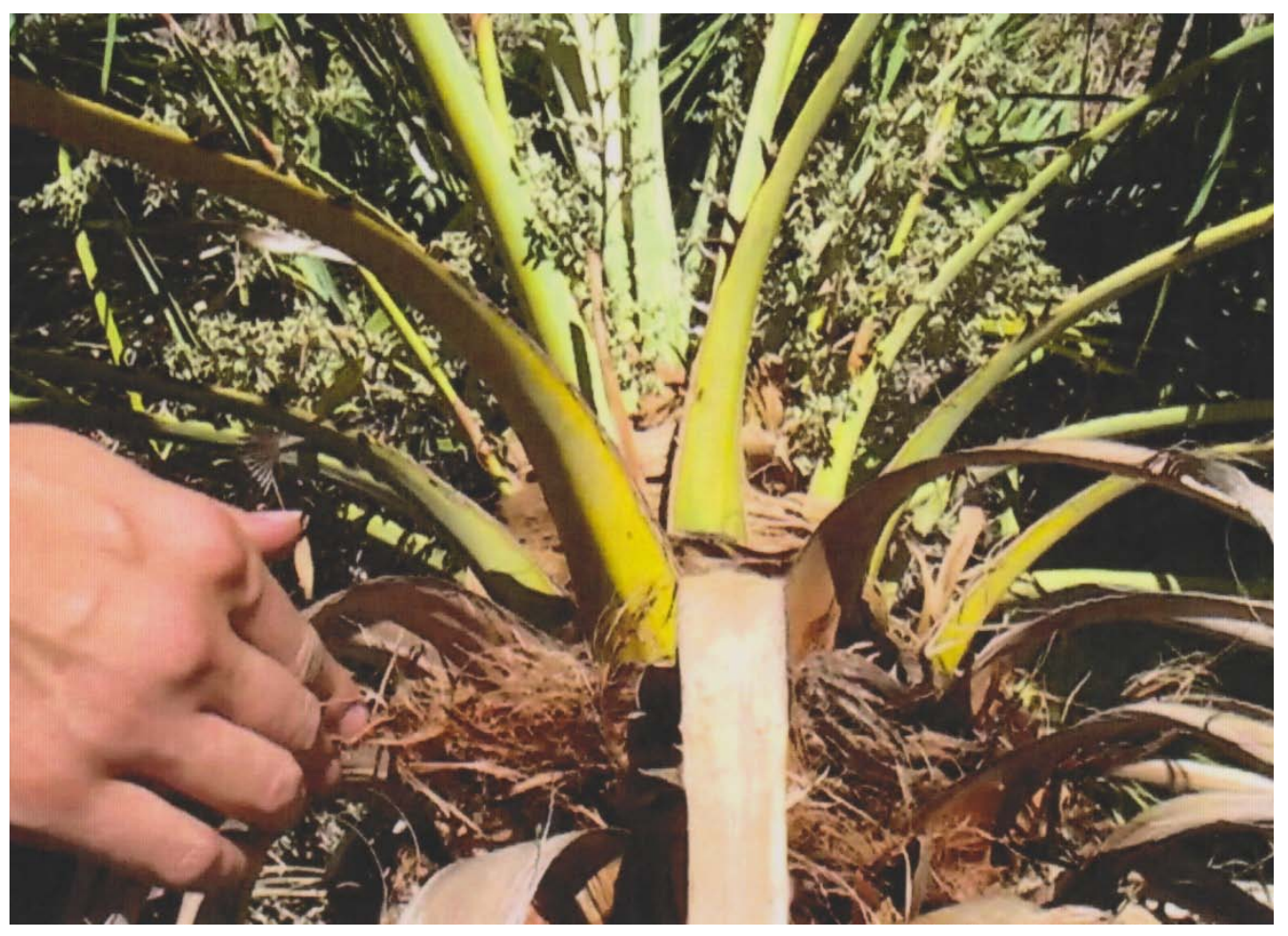

Figure 2.5 Inflorescence and frond petioles are secured by sheathes of cirrus and arranged in whorls. This adult was harvested adult from Plot 5 (Photo by Joan Ngo). 
C. alba can bloom twice between the months of August to October (Figure 2.6). The flowers have a potently sweet fragrance. Honey bees (Hymenoptera) have been observed as pollinators in Alto Paraguay. Flies and beetles are known pollinators for other palm species within the Arecaceae family and suspected for C.alba. Birds are another potential pollinator for the hermaphroditic palm (Moraes 1991; Mereles 1999, 2001).

The inflorescence rachises are found toward the center of the crown (Figure 2.5). The rachises are $0.5 \mathrm{~m}$ to $2 \mathrm{~m}$ long. The main axis contains smaller branches that carry clusters of trimeric flowers (Tomlinson 1979; Peña-Chocarro et al. 2006).

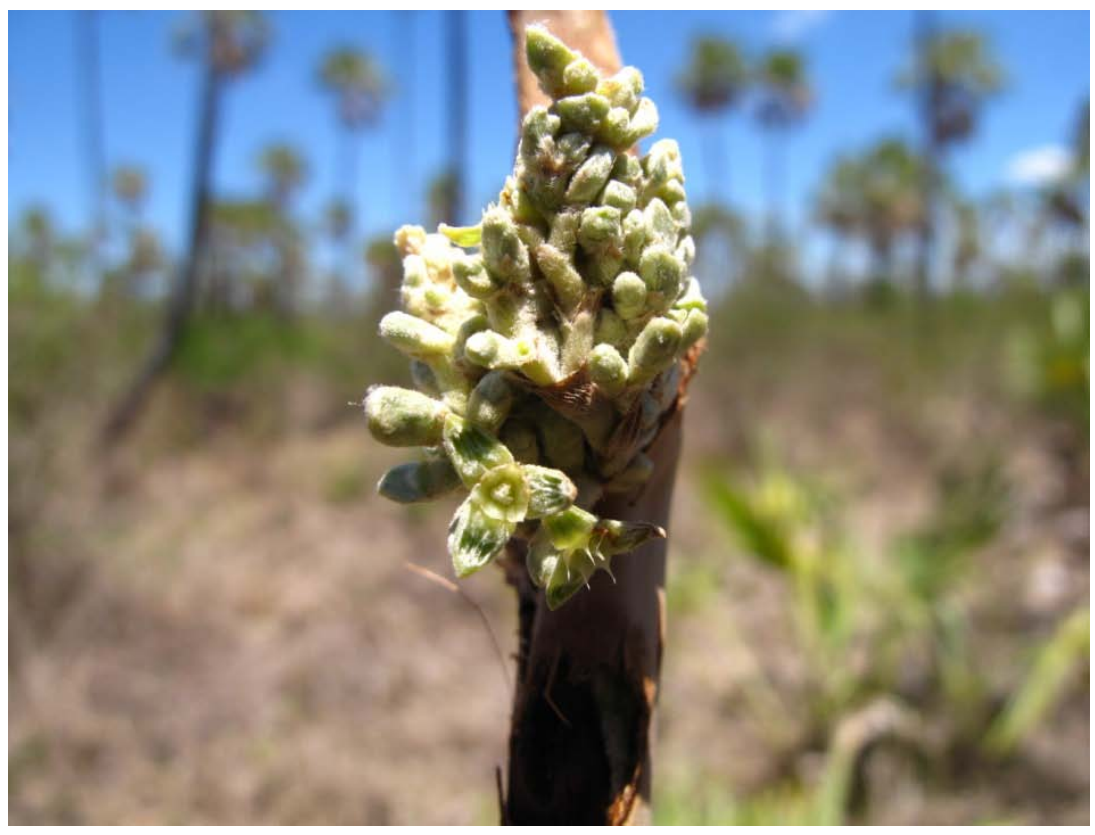

Figure 2.6. Budding trimeric flowers November, 2010 (Photo by Joan Ngo). 


\section{Seed Dispersal}

Seed dispersal is often considered a key variable when interpreting spatial distribution patterns of a particular species (Barot et al. 1999). C. alba have an $\mathrm{R}$ species reproduction strategy. A single palm can produce up to 97,000 light brown, ovoid fruits per year (Grassia 2010). The fruits are smaller when compared to other palm species in Paraguay, ranging in size from 1.0 to $1.5 \mathrm{~cm}$ (López et al. 1987; Schessl 1993; PeñaChocarro et al. 2006). Once palm fruits fall from the tree, they can take up to 4 months to germinate (Grassia 2010).

C. alba has been found to flower twice per year, but as a whole population, the palms do not all produce their flowers or fruits in sync (Mereles 1999). Although palms may bloom and produce fruit irregularly throughout the seasons, the majority of palm populations drop their fruits in the late winter and early spring. This time of year coincides with the sporadic rainfalls, strong northern winds, and fire season (Mereles 1999, 2001). Wind could be an important factor for palms' seed dispersal, dislodging the light fruits that remain tightly attached to the inflorescence (Orozco-Segovia et al. 2003).

C. alba's fruits provide food for both forest and savanna animals. The Greater Rhea (Rhea Americana) and White-lipped peccary (Tayassu pecari) are among the animals that scavenge fruits during the dry season when the diversity of food sources is low (Moraes 1991; Renshaw 2002; Keuroghlian et al. 2009). Bats, the maned wolf (Chrysocyon brachyurus), and small rodents are other potential predators of the fruit (seed) (OrozcoSegovia et al. 2003; Almeida \& Galetti 2007). 


\section{Use by Humans}

Since the palm is readily accessible, it has been used locally in projects such as building tree fences, garbage receptacles, roofs, and stages for community events (Michalowski 1958; López et al. 1987; Moraes 1989). More commonly, C. alba stems are harvested for telephone poles and housing frames. Local residents acknowledge that the palm is not as durable as some of the other local woods, yet the palm still provides them with a wood resource because it is more readily available and more economical in the short term. Families state that the black palms can last 5 to 10 years before rotting.

In the 1970s, C. alba was harvested to sell in Argentina as electric poles. This provided jobs for some of the Chamacoco Indians. In Argentina, they are also used as plant holders, drinking fountains, and in urban landscaping at shopping malls and street medians (Grassia 2010).

Palms are used both for household materials and for food consumption among different indigenous tribes of the Chaco. The Chamacoco (Ishyr tribe) of Bahía Negra District weave emergent leaf shoots into hats, fans, pot-holders, baskets, and other decorative crafts (López et al.1987). Fallen palm inflorescences are also used to make brooms. The Chamacoco harvest the meristem heart as a food source while other tribes, such as the Ayoreo, boil it or cook it in burning ashes. It can also be eaten raw. Along with other palms species, C. alba is used as a salt substitute (López et al. 1987; SchmedaHirschmann 1994; Renshaw 2002; Peña-Chocarro et al. 2006). 


\section{Chapter 3. Methods}

\section{$\underline{\text { Site Description }}$}

The study site falls within the Humid Chaco palm savannas of Paraguay, bordering Brazil, W 2004-5', S 58¹7-16', with elevations of 82-85 m. Temperature ranges from $12^{\circ}$ celsius to $40^{\circ} \mathrm{C}$ with average rainfall of $995 \mathrm{~mm}$ per year (DMH 2011;

Riveros 2010; WMO 2011). The rainy season is from September to April, with December and January having the greatest rainfall (Figure 3.1) (Mereles 2001; DMH 2011). Southerly winds bring cooler temperatures while northerly winds generate warmer temperatures. Winds are strongest during the end of the dry season when fires are more common (Tutiempo World Weather 2010).

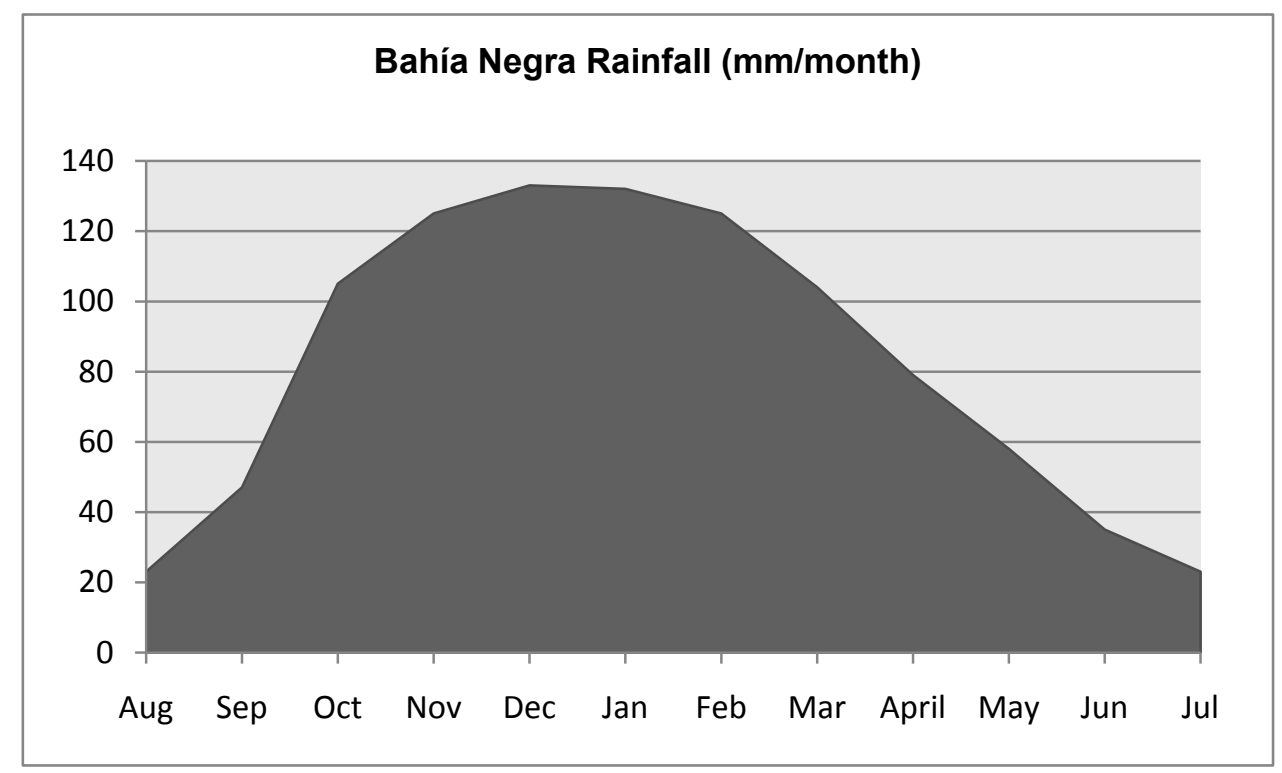

Figure 3.1 Monthly precipitation averaged over 64 years (Data Source WMO 2011)

The study was conducted on the Biological Reserve, Tres Gigantes, which is a part of an alluvial floodplain. Spanning west from the Pantanal wetlands at the Paraguay River, the vegetative communities change from riparian forests and frequently flooded monoculture stands of $C$. alba to drier open savannas that are less frequently flooded. Continuing west the land gradually increases in altitude and the vegetation is influenced by 
seasonal rainfall. Aside from the cattle ranchers that occupy the land less than fifty $\mathrm{km}$ west of the Paraguay River, this region of the Chaco fosters remnants of quebracho forests that were heavily harvested in the late 1960s through the 1970s. The Chaco scrub forests support tree species including, but not limited to, Acacia spp., algorrobo (Prosopis spp.), guayacán (Cesalpinia paraguariensis), mistol (Ziziphus mistol), guaimi pire (Ruprechtia triflora), Lonchocarpus nudiflores and "labonales" containing Schinopsis balansae and Tabebuia nodosa. (Navarro 2005; Mereles 2005).

C. alba dominates both the overstory and the midstory of the study plots. The understory is codominated by members of Poaceae and Fabaceae family (Acacia and Albizia genera) with heights found at 1 to 2.5 meters (Figure 3.3) and accompanied by members of the Verbenaceae, Asteraceae, and Apocynaceae families. Two seasonal ponds fell more than 200 meters away from study plots. Other changes in landscape included 2 woody scrub patches. A small woody patch was found 30 meters north of Plot 3 (Figure 3.4), while the edge of a longer fragmented strip (less than 50 meters) of woody scrub was in the northeast side of Plot 5. 


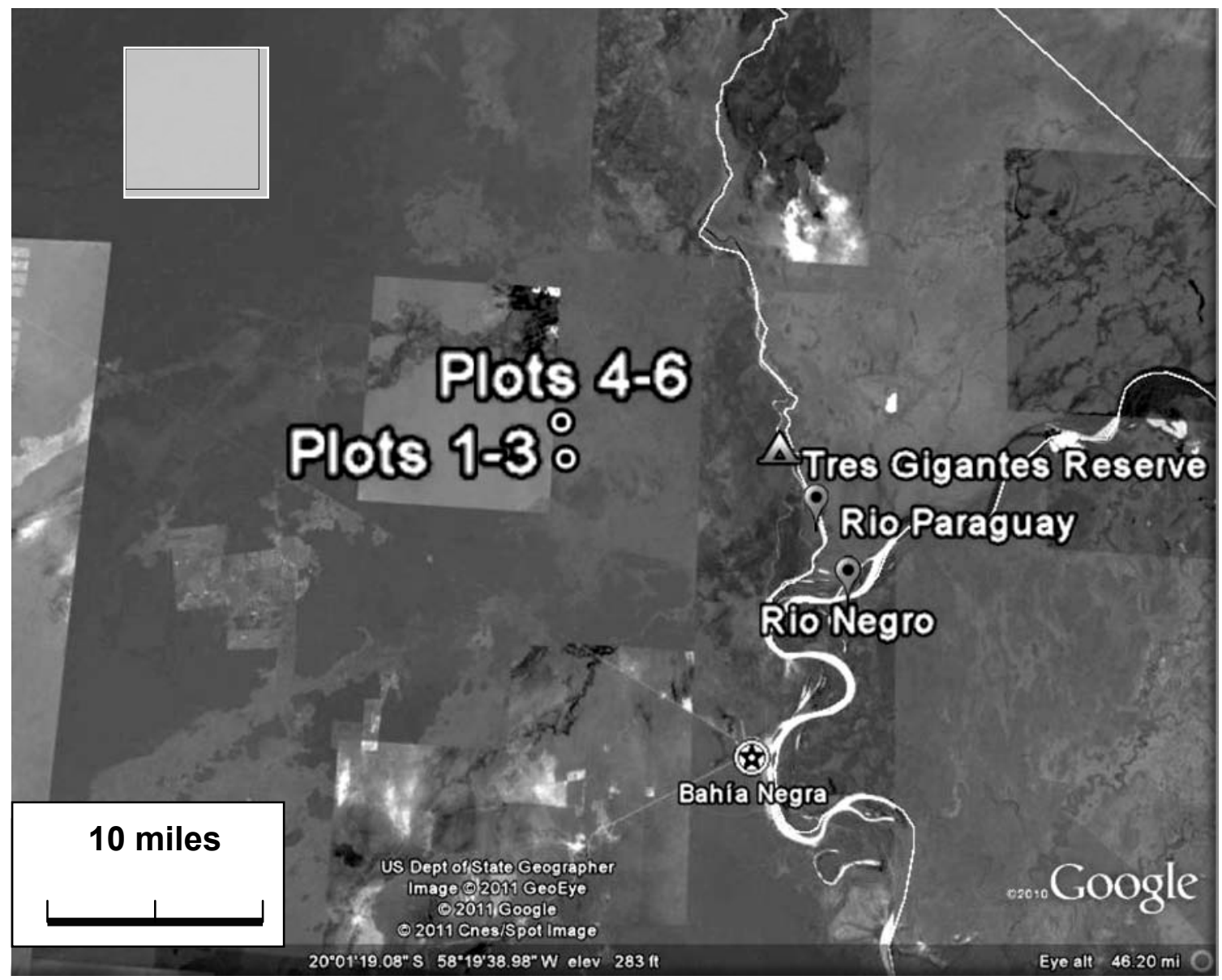

Figure 3.2. Study plots within 14 km (8.7 miles) of the Biological Reserve, Tres Gigantes. 


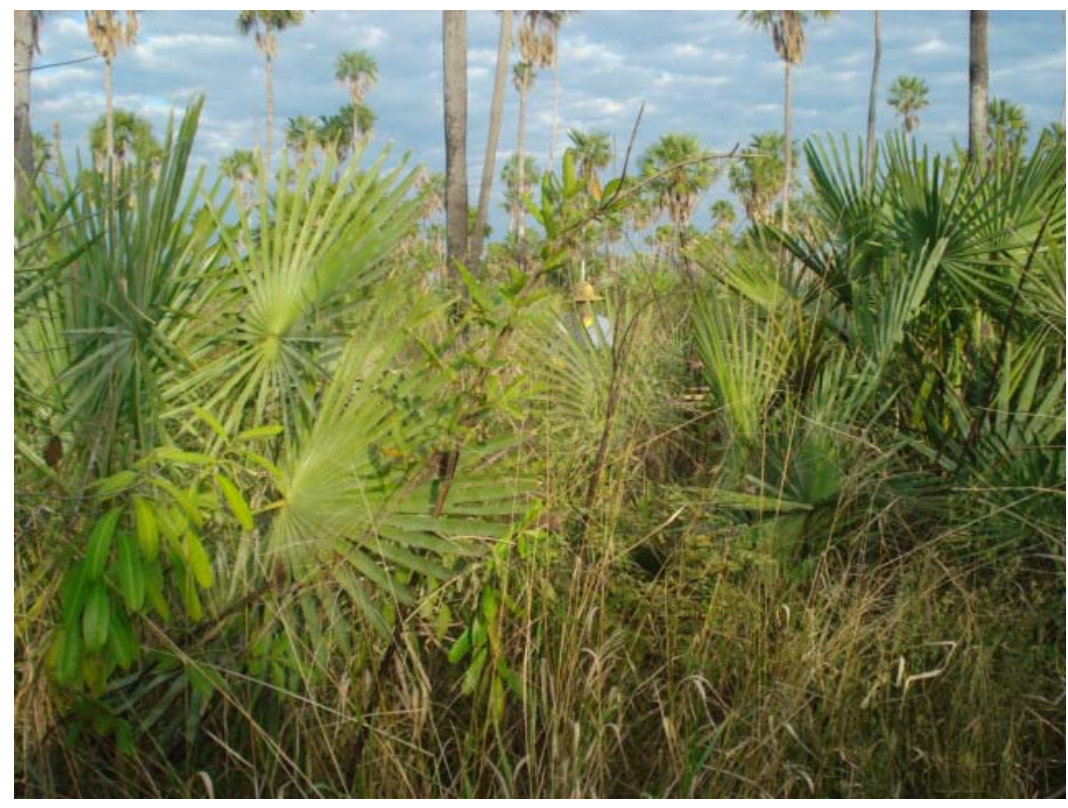

Figure 3.3. Juvenile palms in understory codominated with grasses, and regenerating woody scrub.

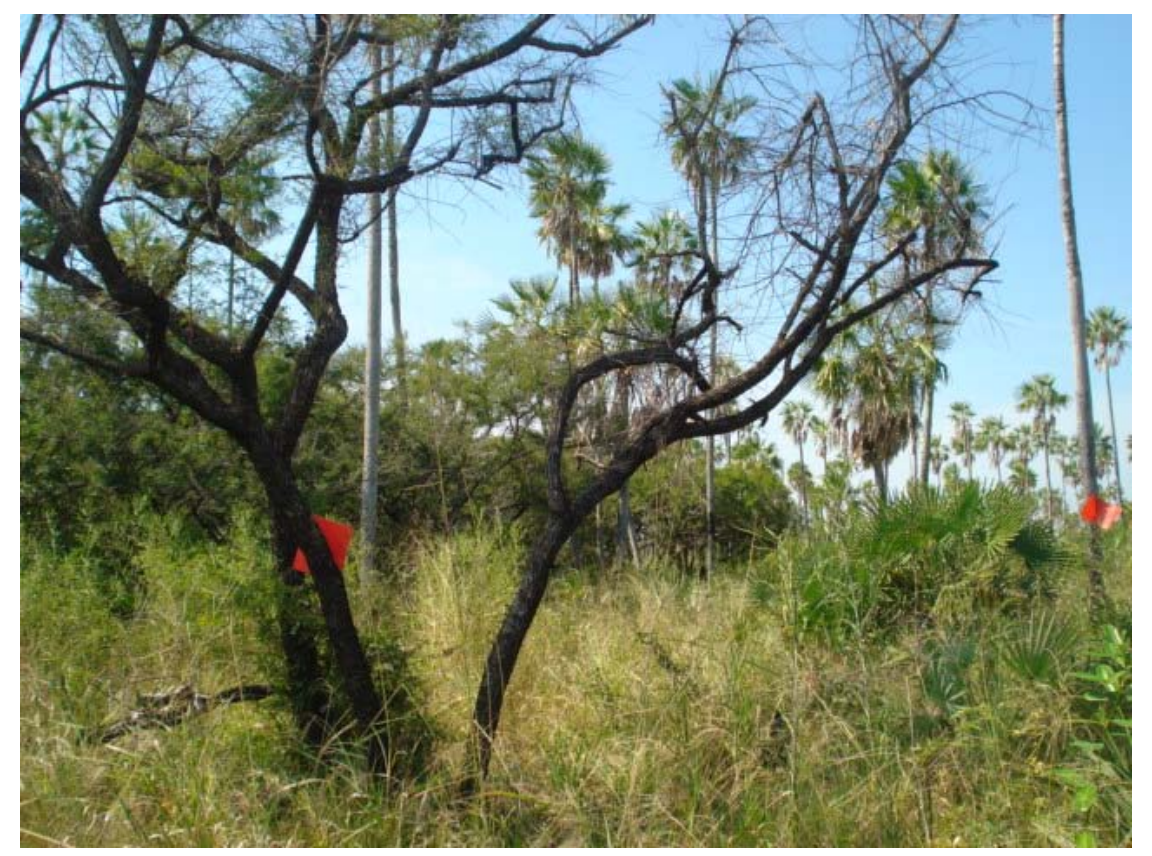

Figure 3.4. Woody scrub patch of Fabacea spp 30 meters north of Plot 3 (Square flag against tree trunk is $0.28 \times 0.22 \mathrm{~m})$. 
Fire disturbance occurs regularly throughout the region. The region had experienced its last fire in September of 2009 and has a fire return interval of one to five years. The pasture clearing practices of ranchers located beyond the north and eastern borders along with strong northerly winds are often the cause for the spread of fires. Prior to the land reserve purchase, the land was previously owned by three to seven families between the 1960s and 1970s. The land was used for small scale ranching carrying over 3,000 cattle and palm harvesting. The land is not suitable for continuous ranching due to irregular large scale floods.

\section{Site Selection \&o Data Collection}

Plots were chosen randomly from savanna palm stands within a $0.5 \mathrm{~km}$ radius of two focal points. Each plot was a 50x 50m quadrant. Random coordinates were generated from two focal points within an area appearing to have similar succession patterns. The plots are not replicates and statistical analysis was performed on each plot separately.

A preliminary trip to the savannas was made in April of 2010 and the first set data was collected from Plots 1-3 during the middle of the-dry season (winter). Field measurements for Plots 4-6 were taken during the end of a light drought in November, 2010. Any palms completely defoliated or showing signs of stem damage were noted and included in the data set.

All palms with a stem of at least $1 \mathrm{~m}$ height were marked using a handheld global positioning system (GPS) (Garmin Etrex, Garmin Ltd., Kansas, USA). Several sets of ground truthed points showed that the measurements were typically accurate within 1 to 2 $\mathrm{m}$. Diameter breast heights were recorded only for palms of at least $1.5 \mathrm{~m}$ stem height and lacking petiole sheathes which could bias diameter measurements. Juveniles had an established stem of at least $1.0 \mathrm{~m}$ and were less than $3.5 \mathrm{~m}$ in height. Height in this study does not include crowns. Adults were classified as all palms with stem heights $\geq 3.5 \mathrm{~m}$. Palms which did not bear fronds were included. In measuring heights, the hypsometer technique was used for palms $\geq 5 \mathrm{~m}$ while shorter palms were measured directly using a flagged, three meter pole. Understory vegetation of study area was photographed during each excursion: late rainy season, dry season, and late dry season. Herbarium samples were submitted to Universidad Nacional de Asunción to assist in identification. 


\section{Data Analysis}

Ripley's K was calculated using the Spatstat package (Baddeley \& Turner 2005) in R project software (www.r-project.org; R Development Core Team 2010). Ripley's K, Diggle's F, and Diggle's $G$ tests were executed to assess total palms with stems $\geq 1 \mathrm{~m}$ (Baddeley \& Turner 2005). All three were used because each function offers different sensitivities. Diggle's $F$ and $G$ consider the total area of a population, and are more dependent of density than Ripley's K. Diggle's G is more sensitive to patterns of regularity while $\mathrm{F}$ is more sensitive to clustering. The transformed Ripley's $\mathrm{K}$ using $\mathrm{L}(\mathrm{r})$ is sensitive to clustering, but offers the advantage of considering a population independent of its density (Ripley 1981; Cressie 1993; Barot et al. 1999). After analyzing the first population listed below with Diggle's F, Diggle's G, and Ripley's K, the population was separated into adult and juvenile classes based upon reproductive height of C. alba (Moraes 1991). The juvenile and adult populations were analyzed using the transformedRipley's K method.

The three populations analyzed with Ripley's K method include:

1.) Total palms: all palms per plot of at least 1 meter height

2.) Juveniles: palms with stem heights of at least $1 \mathrm{~m}$, less than $3.5 \mathrm{~m}$

3.) Adults: palms with stem heights greater than $3.5 \mathrm{~m}$

Each of the six plots contained the three palm populations, resulting in 18 different graphs displaying the transformed Ripley's K. The null hypothesis for all 18 calculation sets was that the given population was randomly distributed. The alternative hypothesis was that patterns were either clustered (aggregated) or more dispersed (regular or repulsed).

The theoretical line on these graphs was generated using the following formula:

$$
L(r)=\sqrt{\frac{A \sum_{i=1}^{N} \sum_{j=1, j \neq 1}^{N} k(i, j)}{\pi \mathrm{N}(\mathrm{N}-1)}}
$$


Where $\mathrm{L}(\mathrm{r})$ is transformed Ripley's $\mathrm{K}, \mathrm{N}$ is the number of palm individuals with an established stem of at least $1 \mathrm{~m}$. The $k$ reflects the relationship between two palm trees. Any initial palm reference $(i)$ on the plot and a tally of all other palm trees $(j)$ that fall within palm i's neighborhood as defined by the radial distance $(r)$, in meters.

Confidence envelopes were generated using 35 Monte Carlo simulations. These pseudo-forests modeling random distribution were compared to the observed values $\mathrm{L}(\mathrm{r})$ values for a given palm population. When an observed $\mathrm{L}(\mathrm{r})$ value is greater than the theoretical L(r) and lies outside of the gray confidence envelopes, the pattern is clustered and spatial randomness is rejected as a null hypothesis. When the $L(r)$ values lie below the theoretical and outside the lower envelope, spatial randomness is again rejected and patterns are considered more dispersed. Regularity and repulsion are types of more dispersed patterns. 


\section{Chapter 4. Data}

A total of 363 palms were measured in the six $50 \times 50 \mathrm{~m}$ plots. The complete data set is shown in Appendix A. Palm number, dbh size distribution, the mean heights, and stand height structure varied considerably from plot to plot (Figure 4.1, Table 4.1, Figure 4.2, Table 4.2) Plot 1 has the highest number of juveniles, 43, and Plot 2 has the lowest with 14 (Figure 4.1). Plot 4 had the highest number of adults. Plots 3 and 6 had approximately 1:1 ratios of adults to juveniles.

Basal area and palm densities varied among the six plots (Table 4.1). Plot 4 has the highest basal area and palm densities, with $63 \%$ of the population represented by adult palms. Basal area was more directly proportional to the percent of adult population than to total palm densities.

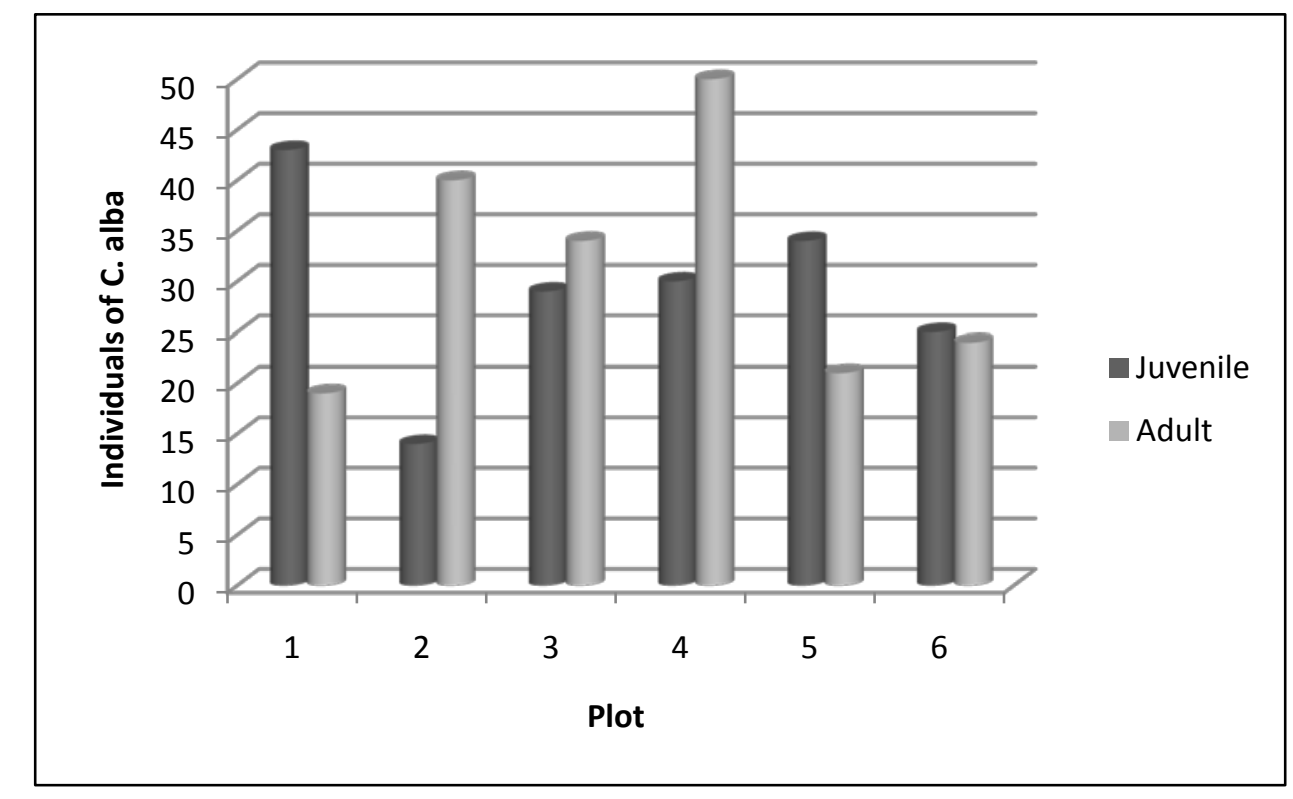

Figure 4.1. Palms with stem height $1 \mathrm{~m}$ to $3.5 \mathrm{~m}$ are juveniles, while adults are all standing palms $\geq 3.5 \mathrm{~m}$ height. 
Table 4.1

Total palm individuals with stem height $\geq 1 \mathrm{~m}$

\begin{tabular}{ccccccc}
\hline Plot & Total & Palms ha $^{-1}$ & \% Adults & $\begin{array}{c}\text { Basal area } \\
\mathbf{m}^{2} \mathbf{h a}^{-1}\end{array}$ & $\begin{array}{c}\text { Juvenile: } \\
\text { Adult }\end{array}$ & Mean Ht \\
\hline 1 & 62 & 248 & 30.6 & 3.42 & $2.3: 1.0$ & 2.8 \\
2 & 54 & 216 & 74.1 & 3.02 & $0.4: 1.0$ & 7.2 \\
3 & 63 & 252 & 53.1 & 2.37 & $0.9: 1.0$ & 5.5 \\
4 & 80 & 320 & 63.3 & 4.89 & $0.6: 1.0$ & 4.7 \\
5 & 55 & 220 & 38.2 & 1.73 & $1.6: 1.0$ & 3.6 \\
6 & 49 & 196 & 49.0 & 2.52 & $1.0: 1.0$ & 4.0
\end{tabular}

*Basal area does not include juvenile palms of a height less than $1.5 \mathrm{~m}$ 


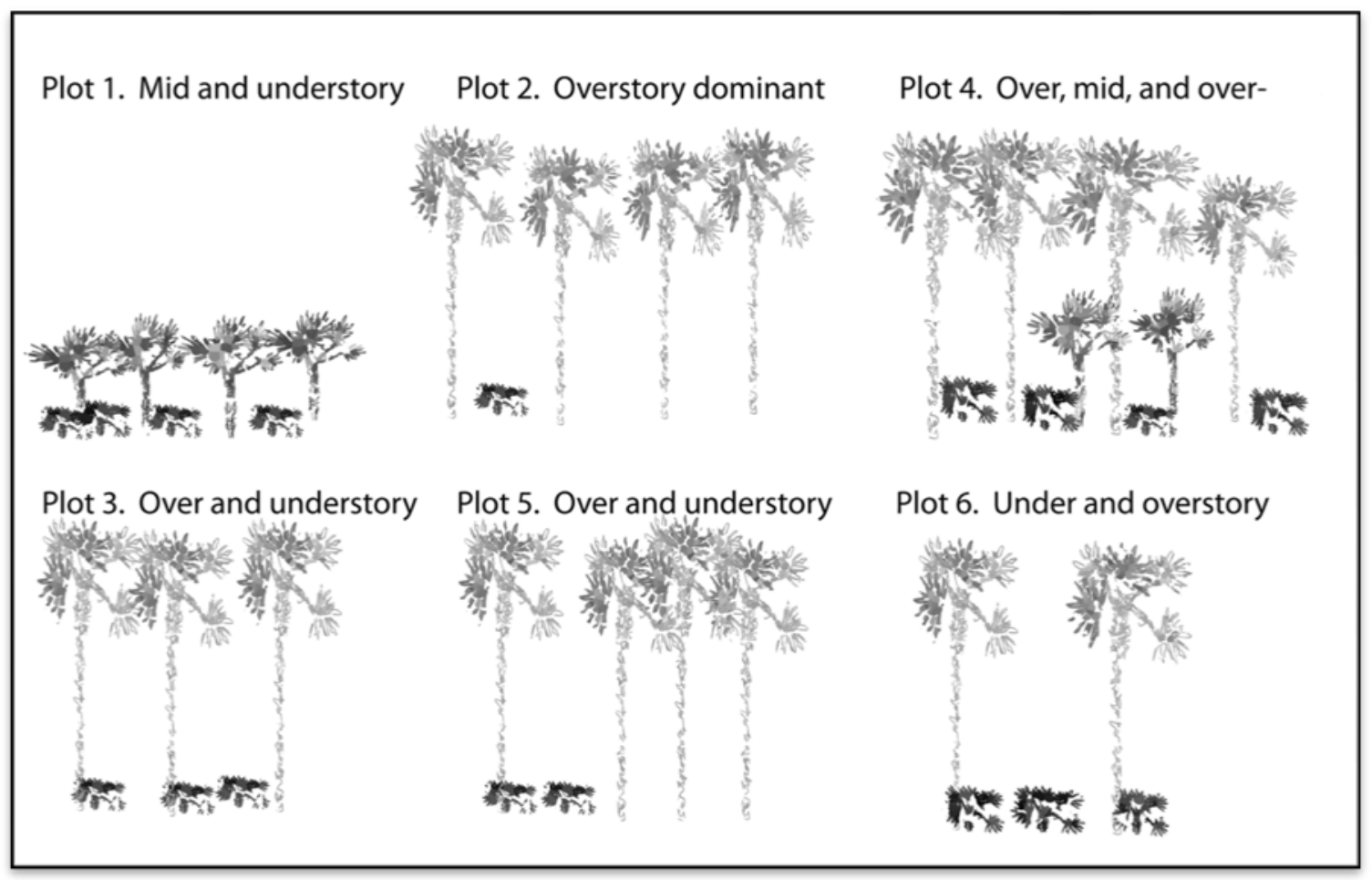

Figure 4.2. The height structure of palms in each plot occupying the under, mid, and overstory. Palms with heights $\leq 3$ meters were defined as understory, while midstory was defined for palms of 3.5 to 5.5 meter heights. Overstory palms had heights of 5.5 to 15.5 meters. Each palm figure represents 10 to 15 palms rounded up to the nearest ten (see Table 4.2). 
Table 4.2

The number of palms distributed by height class into stand structure for each plot.

\begin{tabular}{rccccccc}
\hline Stand Level & $\begin{array}{c}\text { Height } \\
\text { Bracket }\end{array}$ & Plot 1 & Plot 2 & Plot 3 & Plot 4 & Plot 5 & Plot 6 \\
\hline Understory & $1.0 \mathrm{~m}$ & 2 & 1 & 10 & 25 & 34 & 25 \\
Understory & $1.1-3.0 \mathrm{~m}$ & 41 & 13 & 20 & 2 & 0 & 0 \\
Midstory & $3.1-5.5 \mathrm{~m}$ & 36 & 3 & 1 & 16 & 0 & 3 \\
Overstory & $5.5-15 \mathrm{~m}$ & 0 & 36 & 33 & 38 & 21 & 21
\end{tabular}

Each plot had a different stand height structure with the exception of Plots 3 and 6 having nearly 1:1 ratios of juveniles to adults. Plots 1,2 , and 4 were differ in demographic composition (Figure 4.2 top row \& Table 4.2). Plot 1 is a young stand comprised mostly of palms in the understory. Plot 2 is an older stand comprised with the most palms occupying the overstory. Both stands had palms too small ( $<1 \mathrm{~m}$ height) to be included in this study (Figure 3.3 Plot 2). Plot 4 had the most prominent midstory, giving it the most even structure as well. Plots 3, 5, and 6 each have population demographics divided among the understory and overstory (Figure 4.2 bottom row). Plots 3 and 6 were most similar in structure. A patch of midstory woody scrub was located approximately 30 meters north of Plot 3 (Figure 3.4). Plot 5 contain a patches of woody scrub in its northeast quadrant, and like plot 3, appeared to have less recruitment of young seedlings than Plots 1 and 2 (Figures 3.4 and 4.3). 

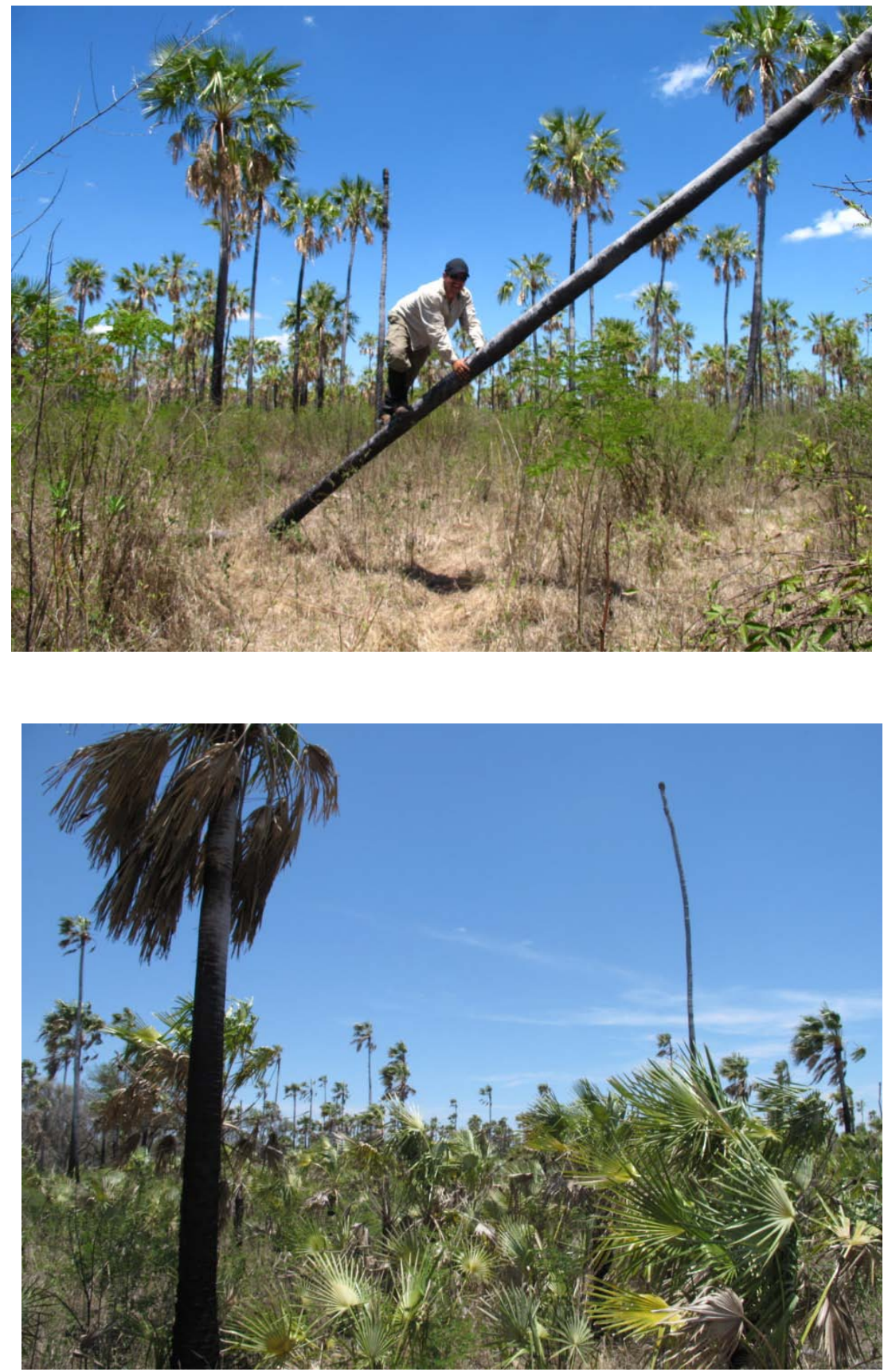

Figures 4.3 and Figure 4.4. (Photo above is Plot 5 and photo below is a stand near plots 4, 5, and 6). Stands are of similar succession type but varying in plant height and succession stage. 


\section{Chapter 5. Results}

The first section, “Total Palms Population;” describes the random and clustered results generated from all palms with a stem height greater than $1 \mathrm{~m}$. The second section, "Juveniles and adults" presents the results where juveniles are clustered and adults consistently have lower L(r) values than juveniles.

\section{$\underline{\text { Total Palms Population }}$}

When Ripley's K was calculated for palms with a stem height greater than $1 \mathrm{~m}$, clustering and randomness were not consistent for all six plots (Figure 5.1). Both clustered and random distributions were found at various scales in Plots 1, 2, 5, and 6. Plots 3 and 4 showed random distributions at nearly all scales. Plot 3 patterns fluctuated above and below the theoretical line within the confidence envelope for random distribution while Plot 4 exhibited random patterns with clustering tendencies at all scales. The Diggle's $F$ and $G$ tests did not show any significant patterns based upon density (Appendix B). 

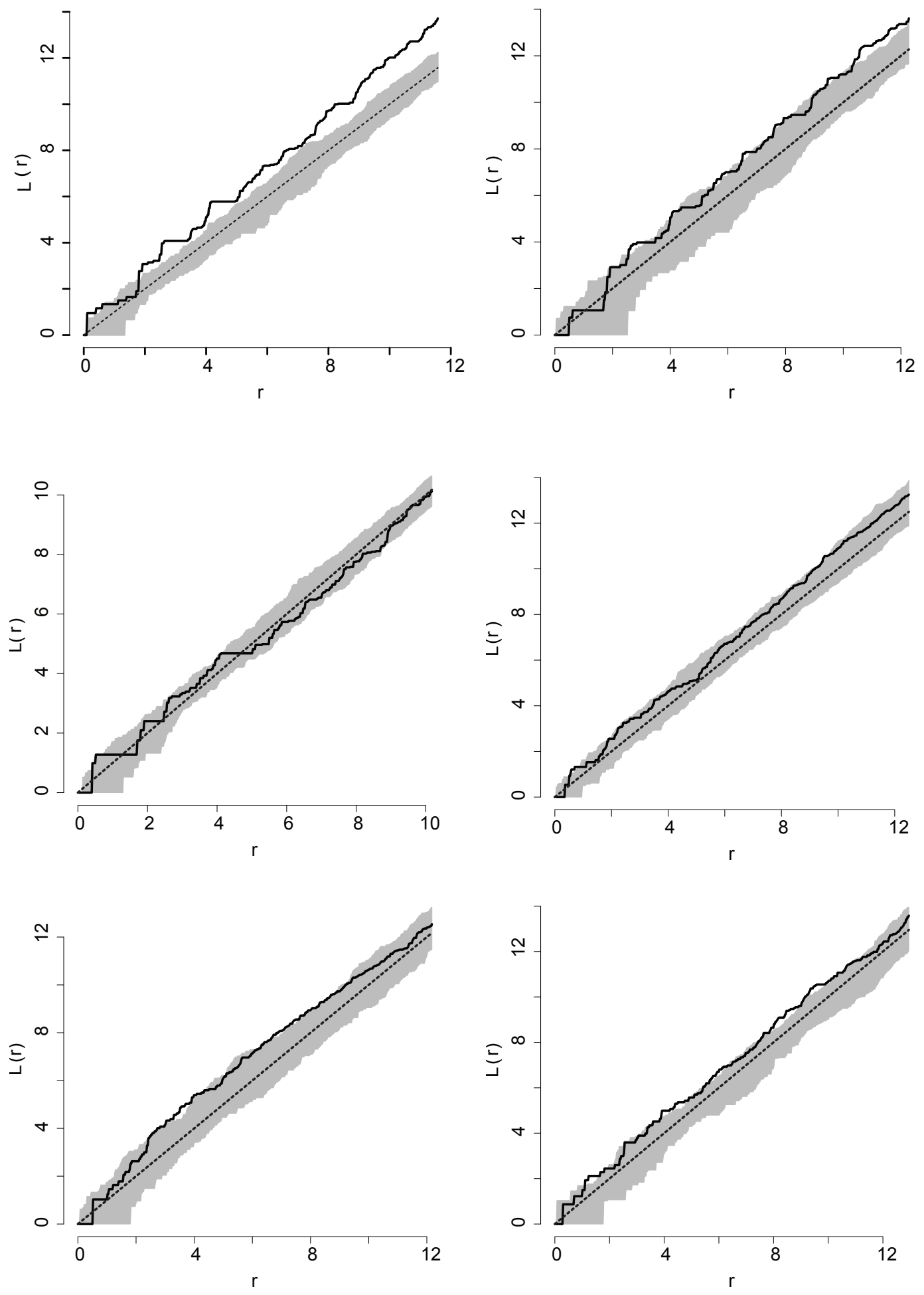

Figure 5.1. Ripley's K test for total palm populations. Plots $1 \& 2$ (top row), Plots $3 \& 4$ (middle), and Plots $5 \& 6$ (bottom) are shown where $r=$ radius and $L(r)=$ the transformed Ripley's K. Total populations display both random and clustered patterns with the exception of Plots 3 and 4. 


\section{Luveniles and Adults}

When the data set was separated by height class, juveniles tended to cluster while adults were more randomly distributed. This occurred in Plots 1, 2, 4, and 5. For Plots 3 and 6, both juveniles and adults were randomly distributed; however, the adults had lower $\mathrm{L}(\mathrm{r})$ values than the juvenile populations for any given $\mathrm{r}$ (Figures 5.2 and 5.3)

In Plot 1, Figure 5.2 (top row), clusters were observed among juveniles at distances $2 \mathrm{~m}$ to $12 \mathrm{~m}$ and adults were found randomly distributed at distances 0 to $12 \mathrm{~m}$. This plot had the highest number of juveniles (Figure 4.1 and Table 4.1) and the lowest number of adults of all six plots. There was a larger confidence envelope in the adult population because the sample size was only comprised of 19 individuals compared to the 43 juveniles. 

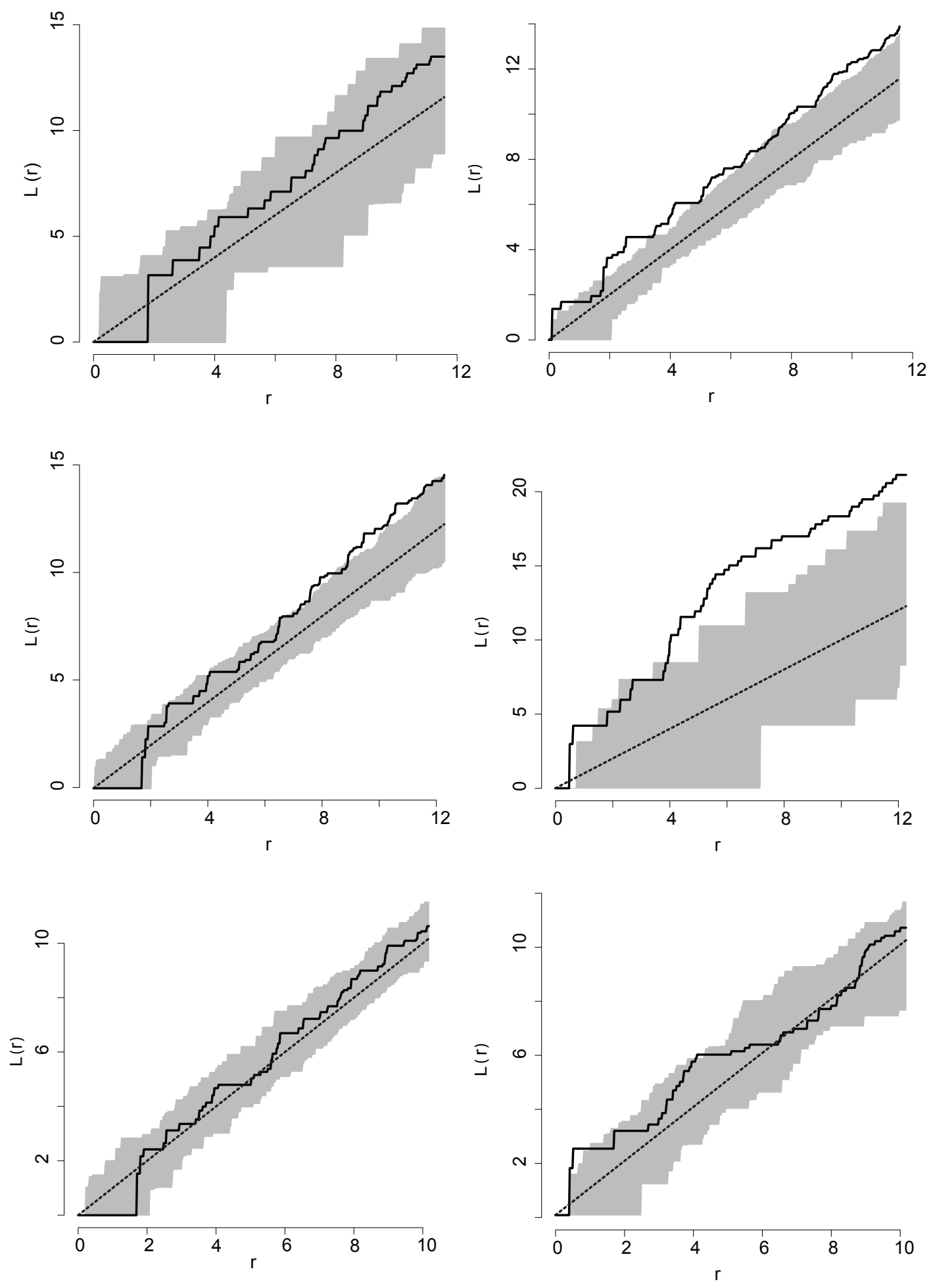

Figure 5.2. Ripley's K test for randomness in adult (left column) and juvenile populations (right column) for Plot 1 (top row), Plot 2 (middle), and Plot 3 (bottom) where $r=$ radius and $L(r)=$ the transformed Ripley's K. Adult populations are less clustered than juveniles, having lower $L(r)$ values than the expected or theoretical values for spatial randomness. 

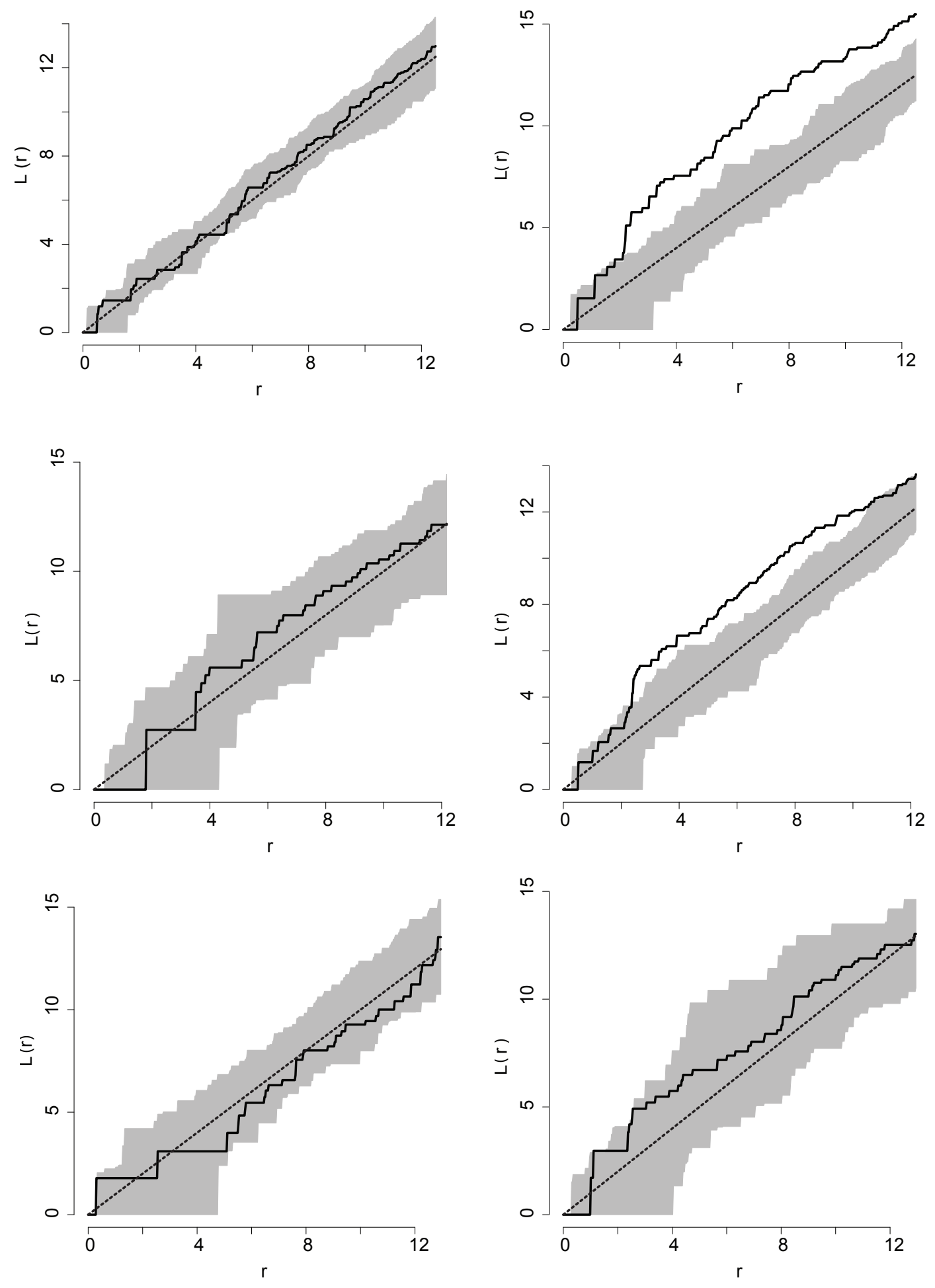

Figure 5.3. Ripley's K test for randomness in adult (left column) and juvenile populations for Plot 4 (top row), Plot 5 (middle), and Plot 6 (bottom) where $r=$ radius and $L(r)=$ the transformed Ripley's $K$. Adult populations are less clustered than juveniles. 
The same basic pattern, where juveniles were clustered while adults were randomly distributed, was found in Plots 2, 4 and 5 at distances $4 \mathrm{~m}$ to $10 \mathrm{~m}$ (Figure 5.3). In Plots 3 and 6, juveniles exhibited a random distribution. Across all plots, however, adults remained less clustered than the juvenile population. In Plot 2, for example, adults were found clustered at 9 to $12 \mathrm{~m}$ (Figure 5.2). The juveniles of plot 2, however, were found clustered along the entire distance 4 to $12 \mathrm{~m}$ and have higher $\mathrm{L}(\mathrm{r})$ values, extending farther from the confidence envelopes than the adult population. Most adult clustering in this plot was accounted for by two linear patches (Figure 5.4). The number of juveniles was low and so most of the clustering represented was from a single circular clump (Figure 5.4). In Plots 3 and 6, the random distributions of juveniles had L(r) values above theoretical random line at distances up to 6.5 meters, fluctuating between random and clustered patterns. The adults, on the other hand, remained close to the theoretical projection for randomness. Plot 6 juveniles also had higher $\mathrm{L}(\mathrm{r})$ values than the adult population that exhibited more regular or dispersed patterns. Spatial symbol diagrams are included in Appendix C.

For the total palms with stems greater than 1 meter, three plots exhibited a random distribution and three plots exhibited a clustered distribution. In separating each plot population by into juvenile and adult height classes a consistent shift from clustered juveniles to less clustered adults was found among all six plots. This shift was found despite differences in density, height ratios, and stand height structure among plots (Table 4.1, Table 4.2, Figure 4.3, Figure 4.4). 


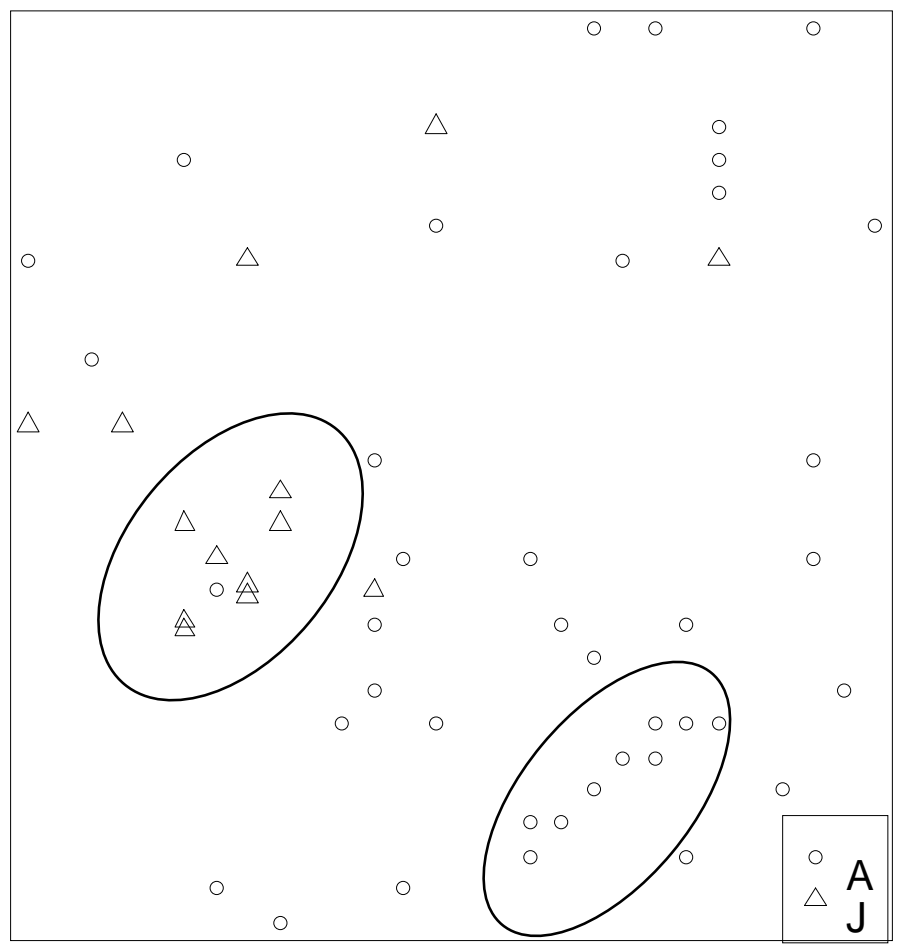

Figure 5.4: Plot 2. A primary patch of adults (small circles) and a patch of juveniles (triangles) attribute to clustering. 


\section{Chapter 6. Discussion}

This shift from clustered juveniles and less clustered adults has also been found in other palm species, both in savanna and montane rain forests (Barot et al. 1999; Svenning 2001), and in other tree species (Pielou 1962; Antonovics \& Primack 1980; Sterner et al. 1986; He 1997; Wiegand et al. 2007; Fangliang et al. 2009) and dominant shrubs (Gibson 1994).

Factors influencing this shift within the palm populations can be separated into two categories:

1. Intrinsic factors- variables innately characteristic to the palms' population dynamics, relative to self-thinning and seed dispersion.

2. Extrinsic factors- elements in the environment, relative to the local scale and time. Examples include moisture availability, soil substrate, fire, wind, and seed dispersers.

Since C. alba is an R strategy species with high fecundity, intrinsic factors such as self thinning and seed dispersion are potential drivers of the shift of patterns in the six plots. Localized seed dispersion may explain the clustering in juveniles, while selfthinning may explain the more random distributions found in adults (Barot et al. 1999; Pielou 1962). Self-thinning among juveniles is reliant on palms reaching equilibrium within a given carrying capacity of their environment. Throughout time $C$. alba could require different levels of nutrients or moisture at different stages of development.

The influence of water availability, soil substrate, and fire disturbance on vegetation patterns are generally more apparent at mesoscales and metascales (GreigSmith 1979; Svenning et al. 2001; Overgaard 2010). Even so, isolated events of fire disturbance, local differences in soil nutrients, and differences in localized moisture availability could alter palm distribution at scales less than 12 meters.

Mechanisms drawn between C. alba's distribution and water availability at the local scale could be affected by soil drainage and climate. The terrain of the study site is fairly flat; however, slight inclines and differences in soil substrate could lead to uneven moisture availability. In terms of climate, the amount of rainfall and time-frame in which 
it falls can vary from year to year. Cloud cover and temperatures that follow rain could affect the rate of soil evaporation and ultimately affect the ability of seedlings to establish roots when the soil is hardened clay

C. alba, like many species, is able to maintain a widespread presence within the floodplains, through traits which serve in both floods and droughts (Parolin 2004). Even so, droughts and large scale flood that might extend inland could induce mortality among juveniles and seedlings. Conversely, both events could play a role in triggering germination. Soil substrates and nutrient patches could also influence the recruitment and clustering (Barot et al. 1999; Svenning et al. 2001). This is particularly important in considering $C$. alba's spatial patterns because the plant is often associated with alluvial flood plains carrying heterogeneous deposits of salt and sediment (Neiff 2001; Hamilton 2002; Vidaurre et al. 2008; Keuroghlian et al. 2009; Navarro et al. 2011). C. alba has been associated with magnesium and heavy silts, but at larger scales across the Chaco (Navarro et al. 2011).

Fire disturbance could affect mortality or trigger seed germination similar to moisture availability (Neiff 2001). Occasionally burnt juveniles were found in the plots (Figure 6.1). Long-term studies assessing meristem burns, palm vitality, and the height of burns on the stems could reveal more about the natural disturbances affect on the palm population. As many savanna fires are light in intensity and move fairly fast using grass as the primary fire fuel, this could provide an environment of reduced competition for the seedlings. Fires can enhance soil quality at a local scale level through the addition of available nutrients. For established plants such as the juveniles, fire could stimulate growth whether it be from increased nutrient loads in soils or from hypercellular repair mechanisms. For adults, fire could possibly stimulate the production of fruit. In relation to plant to plant interactions, annual fires may cause dieback, maintaining woody species in the understory, which ultimately could affect competition of juveniles (Hoffmann 1999; Cabral 2003). Although savanna fires can drive vegetation and trees to cluster at the landscape scale (Fulé \& Covington 1998; Caylor 2006), fire impacts at a local scale are less predictable. 


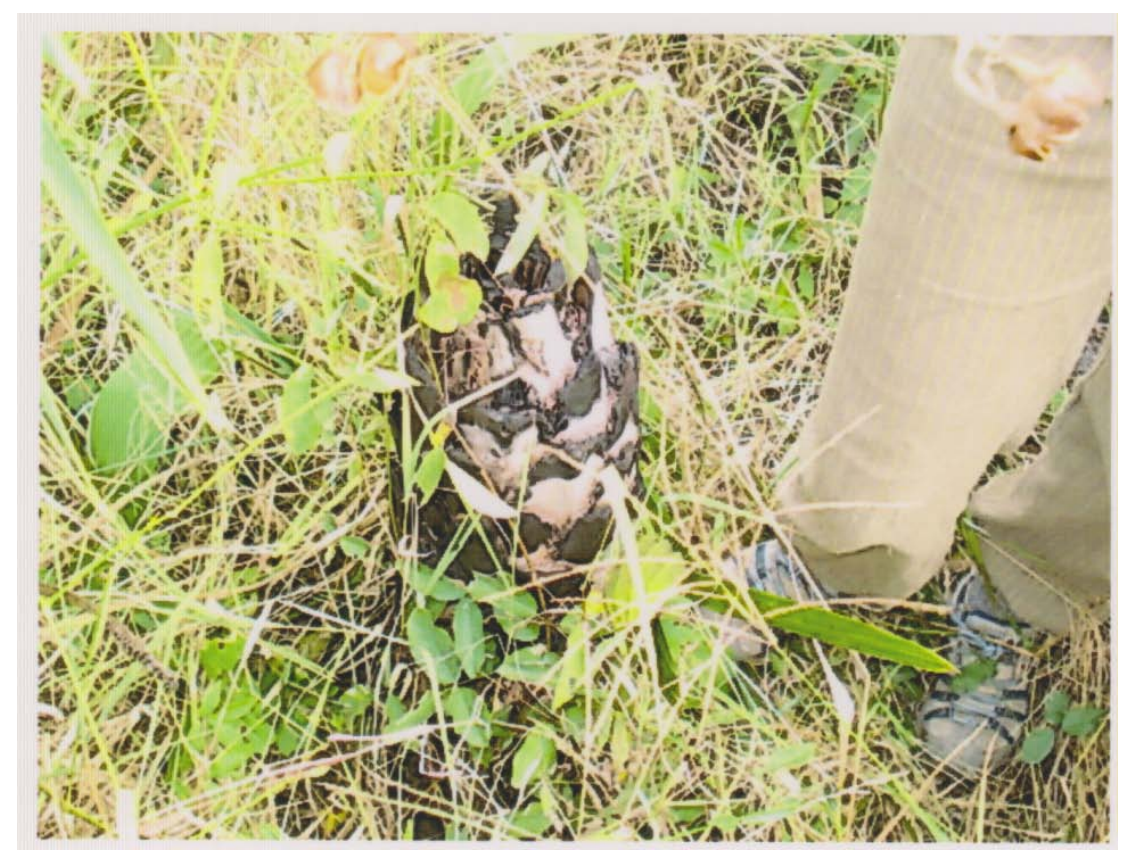

Figure 6.1 Juvenile mortality. Photo taken six months after the 2009 fire.

Lastly, extrinsic factors can also play a role in seed dispersal mechanisms. The wind patterns can play a role in distance and direction in which seeds may be dispersed. Small rodents, bats, and birds can distribute seeds at varying distances, altering spatial patterns. Proximity to forest corridors and seasonal ponds should also be taken into consideration for their ability to harbor a higher diversity and higher population of seed predators (Naiman et al. 1993). Plots 3 and 5 border small patches of scrub less than 0.2 $\mathrm{km}$ and $1.0 \mathrm{~km}$ in diameter, respectively. Over a long-period of time, these patches and corridors can change with fire disturbance.

Future studies addressing the influence of fire, soil, or population dynamics of the palm could help understand the mechanisms driving the clustering in juveniles and less clustering in adults at a small scale. Long-term studies would lead to a deeper understanding of how these ecosystems are changing in response to fire and large scale river floods. These processes can be useful in understanding the basis of savanna ecology and also in understanding the change of patterns over longer periods of climate change and more frequent fire regimes. 


\section{References:}

Almeida, LB \& M Galetti. 2007. Seed dispersal and spatial distribution of Attalea geraensis (Arecaceae) in two remnants of Cerrado in Southeastern Brazil. Acta Oecologica, 32:180-187.

Antonovics, J \& RB Primack. 1980. The ecological and genetic consequences of densitydependent regulation in plants. Annual Review of Ecology and Systematics, 11:411-452.

Baddeley, A \& R Turner. 2005. Spatstat: an R package for analyzing spatial point patterns. Journal of Statistical Software 12(6):1-42. URL: www.jstatsoft.org

Barot, S; J-C \& GJ Menaut. 1999. Demography of a savanna palm tree: Predictions from comprehensive spatial pattern analyses. Ecology, 80(6):1987-2005.

Bravo, S; C Kunst \& R Grau. 2008. Suitability of the native woody species of the Chaco region, Argentina, for use in dendroecological studies of fire regimes. Dendrochronologia, 26(1):43-52

Britton, NL. 1894. Thomas Morong. Bulletin of the Torrey Botanical Club, 21(6):240-244.

Cabral, AC. 2003. Shrub encroachment in Argentinean savannas. Journal of Vegetation Science, 14:145-152.

Caylor, KK. 2006. Pattern and process in savanna ecosystems [15] Pp.259-281 in: P D’Odorico \& A Porporato (eds). Dryland Ecohydrology. Springer.

Cressie, N. 1993. Statistics for Spatial Data. Revised edition. Pp.12-13 in: Wiley Interscience Publication.

Dahlgren, BE \& SF Glassman. 1963. A revision of the genus Copernicia. 1. South American species. Gentes Herbarium, 9:1-232.

Degen, Rosa. 1998. Dinámica Poblacional del Copernicia alba Morong Caranda’y. Dirección de Ordenamiento Ambiental and Estación Experimental Chaco Central. Final Report. Paraguayan Technical Cooperation-Germany. Ministry of Agriculture, GTZ. Pp.102-122. 
DMH (Direccion de Meteorologia e Hidrologia). 2011. Monthly Climate Bulletin: Gerencia de Climatología e Hidrología.

http://www.meteorologia.gov.py/climatologia/bolmensual.pdf. (accessed Jan.12, 2011).

FAO GeoNetwork.[Data source]. 2009. "Land cover of Paraguay".

http://www.fao.org/geonetwork/srv/en/metadata.show?id $=37158 \&$ currTab $=$ simple.

Fulé, P \& WW Covington. 1998. Spatial patterns of Mexican pine-oak forests under different recent fire regimes. Plant Ecology, 134:197-209.

Gardner, S; MR Cabido; GR Valladares \& S Diaz. 1995. The influence of habitat structure on arthropod diversity in Argentine semi-arid Chaco forest. Journal of Vegetation Science, 6:349-356.

Gibson, D \& E Menges. 1994. Population structure and spatial pattern in the dioecious shrub. Journal of $V$ egetation Science, 5:337-346.

Gillson, L. 2004. Evidence of Hierarchical Patch Dynamics in an East African Savanna? Landscape Ecology, 19:883-894.

Grassia, J. 2010. "Palms in Resistencia City" http:/ / palmasenresistencia.blogspot.com/2010/10/copernicia-albaenglish.html?utm_source=BP_recent (accessed Jan. 17, 2011).

Greig-Smith, P. 1979. Pattern in Vegetation. Journal of Ecology, 67:755-779.

He, F; P Legendre \& JV LaFrankie. 1997. Distribution patterns of tree species in a Malaysian tropical rain forest. Journal Vegetation Science, 8(1):105-114.

Hamilton, S. 2002. Hydrological Controls of Ecological Structure and Function in the Pantanal Wetland (Brazil).[Chapter 8] Pp.133-156 in ME McClain (ed.). Ecobydrology of South American Rivers and Wetlands. No. 6 IAHS Special Publication.

Hay, JE. 1993. Tobati: tradition and change in a Paraguayan town. PhD dissertation, University of Florida, USA. p 41. 
Hoffmann, WA. 1999. Fire and Population Dynamics of Woody Plants in a Neotropical Savanna: Matrix Model Projections. Ecology, 80:1354-1369.

Iriondo, M. 1993. Geomorphology and late Quaternary of the Chaco (South America). Geomorphology, 7(4):289-303.

Keuroghlian, A; DP Eaton \& AJ Desbiez. 2009. The response of a landscape species, white-lipped peccaries, to seasonal resource fluctuations in a tropical wetland, the Brazilian Pantanal. International Journal of Biodiversity and Conservation, 1(4):87-97.

López JA; EL Little; GF Ritz; JS Rombold \& WJ Hanh. 1987. Árboles Comunes del Paraguay. Nande Yvyra Mata Kuera. Cuerpo de Paz Colección e Intercambio de Información.

Mereles, F. 1999. Aspectos Fenologicos de la Vegetacion Herbacea de los Palmares de Copernicia alba del Chaco Boreal, Paraguay. Rojasiana, 5(1):67-99.

Mereles, F. 2001. Estudios cuantitativos en las sabanas de "Karandá'y", Copernicia alba Morong, en el Chaco boreal y la sub-cuenca del lago Ypacarai, Paraguay. Rojasiana, $\mathbf{5}(2): 279-290$.

Mereles, F. 2005. Una aproximación al conocimiento de las formaciones vegetales del Chaco Boreal, Paraguay. Rojasiana, 6(2):5-48.

Michalowski, M. 1958. Ecology of Paraguayan Palms. Principles, 2:52-58.

Moraes, M. 1991. Contribución al Estudio del Ciclo Biologico de la Palma Copernicia alba en un Area Ganadera (Espiritu, Beni, Bolivia). Ecología en Bolivia, 18:1-22.

Naiman, RJ; H Decamps \& M Pollock. 1993. The role of riparian corridors in maintaining regional biodiversity. Ecological Applications, 3(2):209-212.

Navarro, G. 2005. Unidades de Vegetación de la Reserva de Biosfera del Chaco Paraguayo. DI Rumiz \& L Villalba (eds). Unidades Ambientales de la Reserva de Biosfera del Chaco Paraguayo. WCS-Fund.DeSdelChaco, Santa Cruz de la Sierra.

Navarro, G; JA Molina \& S Vega. 2011. Soil factors determining the change in forests between dry and wet Chacos. Flora, 206:136-143. 
Neiff, JJ. 2001. Diversity in some tropical wetland systems of South America. Pp 157-186

In B Gopal; WJ Junk; JA Davis (eds), Biodiversity in Wetlands: Assessment, Function and Conservation. Backhuys Publishers [Leiden].

Noblick, LR; SM Salis \& S Braum. 1992. [4890] The New York Botanical Gardens Virtual Herbarium http://sweetgum.nybg.org/vh/specimen.php?irn=945330 (accessed Jan. 19, 2011.

Oliveeira,PS \& RJ Marquis. 2002. Patterns and Dynamics of Plant Populations.[8] Pp 33. The Cerrados of Brazil. Ecology and Natural History of a Neotropical Savanna. Columbia University Press [New York, USA].

Orozco-Segovia, A; AI Batis; M Rojas-Arechiga \& A Mendoza. 2003. Seed Biology of Palms: A Review. Palms, 47(2):79-84.

Overgaard, AB; J-C Svenning; J Dransfield; M Greve \& H Balslev. 2010. Determinants of palm species distributions across Africa: the relative roles of climate, non-climatic environmental factors, and spatial constraints. Ecography Pattern and Diversity in Ecology, 33(2):380-391.

Parolin, P. 2010. Flood-tolerant trees of Amazonian floodplains also tolerant drought. Pesquisas Botanica (Instituto Anchietano de Pesquisas), 61:7-38.

Peña-Chocarro, MC; J de Egea Juvinel; M Vera; H Maturo \& S Knapp. 2006. Pp 37,223,227,229,267. Guía de Árboles y Arbustos del Chaco Húmedo. $1^{\text {st }}$ edn. [Asunción, Paraguay].

Pielou, E. 1962. The use of plant-to-neighbour distances for the detection of competition. Journal of Ecology, 50:357-367.

R Development Core Team. 2010. R: A language and environment for statistical computing. R Foundation for Statistical Computing, Vienna, Austria. ISBN 3-900051-07-0, URL http://www.R-project.org/.

Renshaw, J. 2002. The Indians of the Paraguayan Chaco. Identity and Economy. Pp 85-86. University of Nebraska Press [USA].

Ripley, BD. 1981. Spatial Statistics. Wiley Interscience Publication, 2004. 
Riveros, F. The Gran Chaco.FAO (Food and Agriculture Organization). http://www.fao.org/ag/AGP/AGPC/doc/Bulletin/Granchaco.htm. (accessed Dec. 10, 2010).

Schessl, M. 1993. [3448] The New York Botanical Gardens Virtual Herbarium http://sweetgum.nybg.org/vh/specimen.php?irn=945324/ (accessed Jan. 19, 2011.

Schmeda-Hirschmann, G. 1994. Plant resources used by the Ayoreo of the Paraguayan Chaco. Economic Botany, 48(3):252-258.

Sterner, RW; CA Ribic \& GE Schatz. 1986. Testing for life historical changes in spatial patterns of 4 tropical tree species. Journal of Ecology, 74:621-633.

Svenning J-C, 2001. Environmental heterogeneity, recruitment limitation and the mesoscale distribution of palms in a tropical montane rain forest (Maquipucuna, Ecuador). Journal of Tropical Ecology, 17:97-113.

Tomlinson, PB. 1979. Systematics and Ecology of the Palmae. Annual. Review of Ecology and Systematics, 10:85-107.

Tu'Tiempo World Weather. Wind velocity data of Corumbá, Brasil. www.tutiempo.net/clima/Corumba/01. (accessed Mar 25, 2011).

Valente, HM. 1957. Estudio Quimico de la Madera de Palma, Copernicia alba, Morong. Revista de Investigaciones Forestales, 1(4):53-61.

Vidaurre, T; L Gonzales \& J Ledezma. 2008. Escarabajos Coprofagos (Scarabaeidae: Scarabaeinae) del Palmar de las islas Santa Cruz-Bolivia. Kempffiana, 4(1):3-20.

Vogt, CF \& F Mereles. 2005. Una contribución al Estudio de los Humedales de la Cuenca del Arroyo Ñeembucú, Departmento Ñeembucú, Paraguay. Rojasiana, 7(1).

Wehncke, EV; XL Medellin \& E Ezcurra. 2009. Patterns of frugivory, seed dispersal and predation of blue fan palms (Brabea armata) in oases of northern Baja California. Journal of Arid Environments, 73(9):773-783. 
Wiegand, T; S Gunatilleke; N Gunatilleke \& T Okuda. 2007. Analyzing the spatial structure of a Sri Lankan tree species with multiple scales of clustering. Ecology, 88(12):3088-3102.

Yamashita, C \& YM Barros. 1997. The Blue-throated Macaw Ara glancogularis:

characterization of its distinctive habitats in savannahs of the Beni, Bolivia. Ararajuba. 5(2):141-150. 
Appendix A. Summary Tables and Raw Data

\section{Table A.1}

Palms with stem height $\geq 1 \mathrm{~m}$

\begin{tabular}{cccc}
\hline Plot & Juvenile & Adult & Total \\
\hline 1 & 43 & 19 & 62 \\
2 & 14 & 40 & 54 \\
3 & 29 & 34 & 63 \\
4 & 30 & 50 & 80 \\
5 & 34 & 21 & 55 \\
6 & 25 & 24 & 49
\end{tabular}


Table A.2

Data: Field dbh, height $(\mathrm{Ht})$, and calculations for dbh distributions.

\begin{tabular}{|c|c|c|c|c|c|c|c|c|c|}
\hline Plot & GPS & $\begin{array}{c}\text { BA } \\
\text { Calc }\end{array}$ & BA & $\begin{array}{l}\text { DBH } \\
\text { Count }\end{array}$ & $\begin{array}{l}\text { DBH } \\
\text { Count }\end{array}$ & $\begin{array}{l}\text { DBH } \\
\text { Count }\end{array}$ & $\begin{array}{l}\text { DBH } \\
\text { Count }\end{array}$ & $\begin{array}{l}\mathrm{DBH} \\
\text { raw }\end{array}$ & $\mathrm{Ht}$ \\
\hline$\#$ & $\begin{array}{l}\text { way } \\
\text { pt\# }\end{array}$ & $\begin{array}{l}\mathrm{dbh} / \\
200\end{array}$ & $\left(m^{2}\right)$ & $\begin{array}{l}\text { Null } \\
\text { (cm) }\end{array}$ & $\begin{array}{l}10 \mathrm{~cm} \\
\text { to } \\
14.9 \\
\mathrm{~cm}\end{array}$ & $\begin{array}{l}15 \mathrm{~cm} \\
\text { to } \\
19.9 \\
\mathrm{~cm}\end{array}$ & $\begin{array}{l}\geq 20 \\
\mathrm{~cm}\end{array}$ & $(\mathrm{~cm})$ & (m) \\
\hline P1 & 55 & 0.000 & 0.000 & 1 & 0 & 0 & 0 & 0.0 & 1.0 \\
\hline P1 & 62 & 0.000 & 0.000 & 1 & 0 & 0 & 0 & & 1.0 \\
\hline P1 & 54 & 0.000 & 0.000 & 1 & 0 & 0 & 0 & & 1.2 \\
\hline P1 & 52 & 0.000 & 0.000 & 1 & 0 & 0 & 0 & & 1.3 \\
\hline P1 & 63 & 0.000 & 0.000 & 1 & 0 & 0 & 0 & & 1.3 \\
\hline P1 & 53 & 0.000 & 0.000 & 1 & 0 & 0 & 0 & & 1.4 \\
\hline P1 & 61 & 0.000 & 0.000 & 1 & 0 & 0 & 0 & & 1.4 \\
\hline P1 & 50 & 0.000 & 0.000 & 1 & 0 & 0 & 0 & & 1.5 \\
\hline P1 & 51 & 0.000 & 0.000 & 1 & 0 & 0 & 0 & & 1.5 \\
\hline P1 & 64 & 0.000 & 0.000 & 1 & 0 & 0 & 0 & & 1.5 \\
\hline P1 & 56 & 0.000 & 0.000 & 1 & 0 & 0 & 0 & & 1.7 \\
\hline P1 & 60 & 0.000 & 0.000 & 1 & 0 & 0 & 0 & & 1.7 \\
\hline P1 & 57 & 0.000 & 0.000 & 1 & 0 & 0 & 0 & & 1.8 \\
\hline P1 & 59 & 0.000 & 0.000 & 1 & 0 & 0 & 0 & & 1.8 \\
\hline P1 & 28 & 0.000 & 0.000 & 1 & 0 & 0 & 0 & & 2.0 \\
\hline P1 & 32 & 0.000 & 0.000 & 1 & 0 & 0 & 0 & & 2.0 \\
\hline P1 & 58 & 0.000 & 0.000 & 1 & 0 & 0 & 0 & & 2.0 \\
\hline P1 & 49 & 0.000 & 0.000 & 1 & 0 & 0 & 0 & & 2.1 \\
\hline P1 & 11 & 0.075 & 0.017 & 0 & 1 & 0 & 0 & 14.9 & 2.5 \\
\hline P1 & 14 & 0.069 & 0.015 & 0 & 1 & 0 & 0 & 13.8 & 2.5 \\
\hline P1 & 24 & 0.068 & 0.015 & 0 & 1 & 0 & 0 & 13.6 & 2.5 \\
\hline P1 & 29 & 0.071 & 0.016 & 0 & 1 & 0 & 0 & 14.1 & 2.5 \\
\hline P1 & 34 & 0.081 & 0.020 & 0 & 0 & 1 & 0 & 16.1 & 2.5 \\
\hline P1 & 38 & 0.068 & 0.014 & 0 & 1 & 0 & 0 & 13.5 & 2.5 \\
\hline P1 & 45 & 0.072 & 0.016 & 0 & 1 & 0 & 0 & 14.4 & 2.5 \\
\hline P1 & 46 & 0.079 & 0.020 & 0 & 0 & 1 & 0 & 15.8 & 2.5 \\
\hline
\end{tabular}




\begin{tabular}{|c|c|c|c|c|c|c|c|c|c|}
\hline P1 & 7 & 0.082 & 0.021 & 0 & 0 & 1 & 0 & 16.3 & 3.0 \\
\hline P1 & 12 & 0.078 & 0.019 & 0 & 0 & 1 & 0 & 15.6 & 3.0 \\
\hline P1 & 13 & 0.068 & 0.014 & 0 & 1 & 0 & 0 & 13.5 & 3.0 \\
\hline P1 & 16 & 0.077 & 0.018 & 0 & 0 & 1 & 0 & 15.3 & 3.0 \\
\hline P1 & 18 & 0.068 & 0.014 & 0 & 1 & 0 & 0 & 13.5 & 3.0 \\
\hline P1 & 19 & 0.099 & 0.031 & 0 & 0 & 1 & 0 & 19.8 & 3.0 \\
\hline P1 & 20 & 0.065 & 0.013 & 0 & 1 & 0 & 0 & 13.0 & 3.0 \\
\hline P1 & 23 & 0.071 & 0.016 & 0 & 1 & 0 & 0 & 14.1 & 3.0 \\
\hline P1 & 25 & 0.083 & 0.021 & 0 & 0 & 1 & 0 & 16.5 & 3.0 \\
\hline P1 & 26 & 0.081 & 0.021 & 0 & 0 & 1 & 0 & 16.2 & 3.0 \\
\hline P1 & 27 & 0.088 & 0.024 & 0 & 0 & 1 & 0 & 17.5 & 3.0 \\
\hline P1 & 30 & 0.079 & 0.019 & 0 & 0 & 1 & 0 & 15.7 & 3.0 \\
\hline P1 & 33 & 0.075 & 0.018 & 0 & 0 & 1 & 0 & 15.0 & 3.0 \\
\hline P1 & 39 & 0.075 & 0.017 & 0 & 1 & 0 & 0 & 14.9 & 3.0 \\
\hline P1 & 41 & 0.076 & 0.018 & 0 & 0 & 1 & 0 & 15.2 & 3.0 \\
\hline P1 & 43 & 0.090 & 0.025 & 0 & 0 & 1 & 0 & 18.0 & 3.0 \\
\hline P1 & 44 & 0.063 & 0.012 & 0 & 1 & 0 & 0 & 12.6 & 3.0 \\
\hline P1 & 3 & 0.089 & 0.025 & 0 & 0 & 1 & 0 & 17.7 & 3.5 \\
\hline P1 & 6 & 0.067 & 0.014 & 0 & 1 & 0 & 0 & 13.3 & 3.5 \\
\hline P1 & 15 & 0.077 & 0.018 & 0 & 0 & 1 & 0 & 15.3 & 3.5 \\
\hline P1 & 17 & 0.062 & 0.012 & 0 & 1 & 0 & 0 & 12.4 & 3.5 \\
\hline P1 & 31 & 0.087 & 0.024 & 0 & 0 & 1 & 0 & 17.3 & 3.5 \\
\hline P1 & 35 & 0.079 & 0.019 & 0 & 0 & 1 & 0 & 15.7 & 3.5 \\
\hline P1 & 36 & 0.060 & 0.011 & 0 & 1 & 0 & 0 & 12.0 & 3.5 \\
\hline P1 & 37 & 0.082 & 0.021 & 0 & 0 & 1 & 0 & 16.3 & 3.5 \\
\hline P1 & 47 & 0.101 & 0.032 & 0 & 0 & 0 & 1 & 20.2 & 3.5 \\
\hline P1 & 48 & 0.087 & 0.024 & 0 & 0 & 1 & 0 & 17.4 & 3.5 \\
\hline P1 & 5 & 0.080 & 0.020 & 0 & 0 & 1 & 0 & 15.9 & 4.0 \\
\hline P1 & 8 & 0.081 & 0.020 & 0 & 0 & 1 & 0 & 16.1 & 4.0 \\
\hline P1 & 9 & 0.076 & 0.018 & 0 & 0 & 1 & 0 & 15.2 & 4.0 \\
\hline P1 & 21 & 0.076 & 0.018 & 0 & 0 & 1 & 0 & 15.1 & 4.0 \\
\hline P1 & 40 & 0.105 & 0.035 & 0 & 0 & 0 & 1 & 21.0 & 4.0 \\
\hline P1 & 42 & 0.090 & 0.025 & 0 & 0 & 1 & 0 & 17.9 & 4.0 \\
\hline P1 & 22 & 0.071 & 0.016 & 0 & 1 & 0 & 0 & 14.1 & 4.5 \\
\hline P1 & 4 & 0.101 & 0.032 & 0 & 0 & 0 & 1 & 20.2 & 5.0 \\
\hline
\end{tabular}




\begin{tabular}{|c|c|c|c|c|c|c|c|c|c|}
\hline P1 & 10 & 0.070 & 0.015 & 0 & 1 & 0 & 0 & 13.9 & 5.0 \\
\hline P1 & Sums & $\rightarrow$ & 3.420 & 18 & 17 & 24 & 3 & & \\
\hline P2 & 107 & 0.000 & 0.000 & 1 & 0 & 0 & 0 & & 1.0 \\
\hline P2 & 108 & 0.000 & 0.000 & 1 & 0 & 0 & 0 & & 1.2 \\
\hline P2 & 104 & 0.000 & 0.000 & 1 & 0 & 0 & 0 & & 1.3 \\
\hline P2 & 113 & 0.000 & 0.000 & 1 & 0 & 0 & 0 & & 1.3 \\
\hline P2 & 97 & 0.000 & 0.000 & 1 & 0 & 0 & 0 & & 1.4 \\
\hline P2 & 98 & 0.000 & 0.000 & 1 & 0 & 0 & 0 & & 1.4 \\
\hline P2 & 114 & 0.000 & 0.000 & 1 & 0 & 0 & 0 & & 1.4 \\
\hline P2 & 100 & 0.000 & 0.000 & 1 & 0 & 0 & 0 & & 1.5 \\
\hline P2 & 106 & 0.000 & 0.000 & 1 & 0 & 0 & 0 & & 1.5 \\
\hline P2 & 112 & 0.000 & 0.000 & 1 & 0 & 0 & 0 & & 1.5 \\
\hline P2 & 111 & 0.000 & 0.000 & 1 & 0 & 0 & 0 & & 1.6 \\
\hline P2 & 95 & 0.000 & 0.000 & 1 & 0 & 0 & 0 & & 1.7 \\
\hline P2 & 105 & 0.000 & 0.000 & 1 & 0 & 0 & 0 & & 1.7 \\
\hline P2 & 110 & 0.000 & 0.000 & 1 & 0 & 0 & 0 & & 1.9 \\
\hline P2 & 85 & 0.069 & 0.015 & 0 & 1 & 0 & 0 & 13.8 & 3.8 \\
\hline P2 & 120 & 0.104 & 0.034 & 0 & 0 & 0 & 1 & 20.8 & 4.0 \\
\hline P2 & 73 & 0.065 & 0.013 & 0 & 1 & 0 & 0 & 12.9 & 4.3 \\
\hline P2 & 89 & 0.077 & 0.019 & 0 & 0 & 1 & 0 & 15.4 & 5.8 \\
\hline P2 & 118 & 0.081 & 0.020 & 0 & 0 & 1 & 0 & 16.1 & 6.5 \\
\hline P2 & 77 & 0.075 & 0.017 & 0 & 1 & 0 & 0 & 14.9 & 7.0 \\
\hline P2 & 80 & 0.071 & 0.016 & 0 & 1 & 0 & 0 & 14.2 & 7.3 \\
\hline P2 & 119 & 0.078 & 0.019 & 0 & 0 & 1 & 0 & 15.5 & 7.5 \\
\hline P2 & 122 & 0.074 & 0.017 & 0 & 1 & 0 & 0 & 14.7 & 8.0 \\
\hline P2 & 70 & 0.063 & 0.012 & 0 & 1 & 0 & 0 & 12.6 & 8.3 \\
\hline P2 & 92 & 0.081 & 0.021 & 0 & 0 & 1 & 0 & 16.2 & 8.5 \\
\hline P2 & 117 & 0.077 & 0.019 & 0 & 0 & 1 & 0 & 15.4 & 8.5 \\
\hline P2 & 90 & 0.080 & 0.020 & 0 & 0 & 1 & 0 & 16.0 & 8.8 \\
\hline P2 & 71 & 0.080 & 0.020 & 0 & 0 & 1 & 0 & 15.9 & 8.9 \\
\hline P2 & 96 & 0.074 & 0.017 & 0 & 1 & 0 & 0 & 14.8 & 8.9 \\
\hline P2 & 91 & 0.073 & 0.017 & 0 & 1 & 0 & 0 & 14.5 & 9.0 \\
\hline P2 & 99 & 0.083 & 0.022 & 0 & 0 & 1 & 0 & 16.6 & 9.0 \\
\hline
\end{tabular}




\begin{tabular}{|c|c|c|c|c|c|c|c|c|c|}
\hline P2 & 109 & 0.073 & 0.017 & 0 & 1 & 0 & 0 & 14.6 & 9.0 \\
\hline P2 & 83 & 0.079 & 0.019 & 0 & 0 & 1 & 0 & 15.7 & 9.3 \\
\hline P2 & 101 & 0.080 & 0.020 & 0 & 0 & 1 & 0 & 16.0 & 9.3 \\
\hline P2 & 76 & 0.080 & 0.020 & 0 & 0 & 1 & 0 & 15.9 & 9.5 \\
\hline P2 & 102 & 0.095 & 0.028 & 0 & 0 & 1 & 0 & 18.9 & 9.5 \\
\hline P2 & 66 & 0.072 & 0.016 & 0 & 1 & 0 & 0 & 14.4 & 9.7 \\
\hline P2 & 72 & 0.084 & 0.022 & 0 & 0 & 1 & 0 & 16.7 & 9.7 \\
\hline P2 & 81 & 0.077 & 0.018 & 0 & 0 & 1 & 0 & 15.3 & 10.0 \\
\hline P2 & 88 & 0.070 & 0.015 & 0 & 1 & 0 & 0 & 13.9 & 10.0 \\
\hline P2 & 103 & 0.083 & 0.021 & 0 & 0 & 1 & 0 & 16.5 & 10.0 \\
\hline P2 & 69 & 0.087 & 0.024 & 0 & 0 & 1 & 0 & 17.4 & 10.3 \\
\hline P2 & 93 & 0.069 & 0.015 & 0 & 1 & 0 & 0 & 13.7 & 10.3 \\
\hline P2 & 94 & 0.068 & 0.014 & 0 & 1 & 0 & 0 & 13.5 & 10.3 \\
\hline P2 & 87 & 0.087 & 0.024 & 0 & 0 & 1 & 0 & 17.4 & 10.4 \\
\hline P2 & 79 & 0.069 & 0.015 & 0 & 1 & 0 & 0 & 13.7 & 10.5 \\
\hline P2 & 121 & 0.099 & 0.030 & 0 & 0 & 1 & 0 & 19.7 & 10.7 \\
\hline P2 & 123 & 0.062 & 0.012 & 0 & 1 & 0 & 0 & 12.4 & 10.7 \\
\hline P2 & 74 & 0.073 & 0.017 & 0 & 1 & 0 & 0 & 14.6 & 10.8 \\
\hline P2 & 67 & 0.068 & 0.014 & 0 & 1 & 0 & 0 & 13.5 & 11.0 \\
\hline P2 & 68 & 0.069 & 0.015 & 0 & 1 & 0 & 0 & 13.7 & 11.3 \\
\hline P2 & 75 & 0.088 & 0.024 & 0 & 0 & 1 & 0 & 17.5 & 12.0 \\
\hline P2 & 78 & 0.079 & 0.019 & 0 & 0 & 1 & 0 & 15.7 & 14.5 \\
\hline P2 & 116 & 0.073 & 0.017 & 0 & 1 & 0 & 0 & 14.6 & 15.0 \\
\hline P2 & Sums & $\rightarrow$ & 3.017 & 14 & 19 & 20 & 1 & & \\
\hline P3 & 133 & 0.000 & 0.000 & 1 & 0 & 0 & 0 & & 1.0 \\
\hline P3 & 138 & 0.000 & 0.000 & 1 & 0 & 0 & 0 & & 1.0 \\
\hline P3 & 140 & 0.000 & 0.000 & 1 & 0 & 0 & 0 & & 1.0 \\
\hline P3 & 146 & 0.000 & 0.000 & 1 & 0 & 0 & 0 & & 1.0 \\
\hline P3 & 152 & 0.000 & 0.000 & 1 & 0 & 0 & 0 & & 1.0 \\
\hline P3 & 158 & 0.000 & 0.000 & 1 & 0 & 0 & 0 & & 1.0 \\
\hline P3 & 163 & 0.000 & 0.000 & 1 & 0 & 0 & 0 & & 1.0 \\
\hline P3 & 172 & 0.000 & 0.000 & 1 & 0 & 0 & 0 & & 1.0 \\
\hline P3 & 175 & 0.000 & 0.000 & 1 & 0 & 0 & 0 & & 1.0 \\
\hline P3 & 178 & 0.000 & 0.000 & 1 & 0 & 0 & 0 & & 1.0 \\
\hline
\end{tabular}




\begin{tabular}{|c|c|c|c|c|c|c|c|c|}
\hline P3 & 160 & 0.000 & 0.000 & 1 & 0 & 0 & 0 & \\
\hline P3 & 170 & 0.000 & 0.000 & 1 & 0 & 0 & 0 & \\
\hline P3 & 176 & 0.000 & 0.000 & 1 & 0 & 0 & 0 & \\
\hline P3 & 141 & 0.000 & 0.000 & 1 & 0 & 0 & 0 & \\
\hline P3 & 127 & 0.000 & 0.000 & 1 & 0 & 0 & 0 & \\
\hline P3 & 166 & 0.000 & 0.000 & 1 & 0 & 0 & 0 & \\
\hline P3 & 167 & 0.000 & 0.000 & 1 & 0 & 0 & 0 & \\
\hline P3 & 139 & 0.000 & 0.000 & 1 & 0 & 0 & 0 & \\
\hline P3 & 147 & 0.000 & 0.000 & 1 & 0 & 0 & 0 & \\
\hline P3 & 165 & 0.000 & 0.000 & 1 & 0 & 0 & 0 & \\
\hline P3 & 177 & 0.000 & 0.000 & 1 & 0 & 0 & 0 & \\
\hline P3 & 132 & 0.000 & 0.000 & 1 & 0 & 0 & 0 & \\
\hline P3 & 174 & 0.000 & 0.000 & 1 & 0 & 0 & 0 & \\
\hline P3 & 173 & 0.000 & 0.000 & 1 & 0 & 0 & 0 & \\
\hline P3 & 142 & 0.000 & 0.000 & 1 & 0 & 0 & 0 & \\
\hline P3 & 182 & 0.000 & 0.000 & 1 & 0 & 0 & 0 & \\
\hline P3 & 187 & 0.000 & 0.000 & 1 & 0 & 0 & 0 & \\
\hline P3 & 135 & 0.000 & 0.000 & 1 & 0 & 0 & 0 & \\
\hline P3 & 190 & 0.000 & 0.000 & 1 & 0 & 0 & 0 & \\
\hline P3 & 168 & 0.000 & 0.000 & 1 & 0 & 0 & 0 & \\
\hline P3 & 184 & 0.088 & 0.024 & 0 & 0 & 1 & 0 & 17.6 \\
\hline P3 & 144 & 0.092 & 0.026 & 0 & 0 & 1 & 0 & 18.3 \\
\hline P3 & 134 & 0.069 & 0.015 & 0 & 1 & 0 & 0 & 13.7 \\
\hline P3 & 171 & 0.069 & 0.015 & 0 & 1 & 0 & 0 & 13.8 \\
\hline P3 & 143 & 0.073 & 0.017 & 0 & 1 & 0 & 0 & 14.6 \\
\hline P3 & 129 & 0.081 & 0.021 & 0 & 0 & 1 & 0 & 16.2 \\
\hline P3 & 164 & 0.097 & 0.030 & 0 & 0 & 1 & 0 & 19.4 \\
\hline P3 & 169 & 0.082 & 0.021 & 0 & 0 & 1 & 0 & 16.4 \\
\hline P3 & 154 & 0.072 & 0.016 & 0 & 1 & 0 & 0 & 14.4 \\
\hline P3 & 151 & 0.067 & 0.014 & 0 & 1 & 0 & 0 & 13.3 \\
\hline P3 & 181 & 0.068 & 0.015 & 0 & 1 & 0 & 0 & 13.6 \\
\hline P3 & 185 & 0.064 & 0.013 & 0 & 1 & 0 & 0 & 12.8 \\
\hline P3 & 186 & 0.060 & 0.011 & 0 & 1 & 0 & 0 & 11.9 \\
\hline P3 & 137 & 0.059 & 0.011 & 0 & 1 & 0 & 0 & 11.8 \\
\hline P3 & 157 & 0.084 & 0.022 & 0 & 0 & 1 & 0 & 16.8 \\
\hline
\end{tabular}




\begin{tabular}{|c|c|c|c|c|c|c|c|c|c|}
\hline P3 & 179 & 0.085 & 0.023 & 0 & 0 & 1 & 0 & 17.0 & 9.0 \\
\hline P3 & 183 & 0.069 & 0.015 & 0 & 1 & 0 & 0 & 13.8 & 9.0 \\
\hline P3 & 134 & 0.065 & 0.013 & 0 & 1 & 0 & 0 & 12.9 & 9.3 \\
\hline P3 & 180 & 0.077 & 0.018 & 0 & 0 & 1 & 0 & 15.3 & 9.3 \\
\hline P3 & 149 & 0.075 & 0.017 & 0 & 1 & 0 & 0 & 14.9 & 9.4 \\
\hline P3 & 155 & 0.063 & 0.012 & 0 & 1 & 0 & 0 & 12.6 & 9.4 \\
\hline P3 & 156 & 0.076 & 0.018 & 0 & 0 & 1 & 0 & 15.2 & 9.4 \\
\hline P3 & 130 & 0.075 & 0.018 & 0 & 0 & 1 & 0 & 15.0 & 9.5 \\
\hline P3 & 162 & 0.061 & 0.011 & 0 & 1 & 0 & 0 & 12.1 & 9.6 \\
\hline P3 & 188 & 0.085 & 0.023 & 0 & 0 & 1 & 0 & 17.0 & 10.0 \\
\hline P3 & 136 & 0.057 & 0.010 & 0 & 1 & 0 & 0 & 11.4 & 10.3 \\
\hline P3 & 145 & 0.069 & 0.015 & 0 & 1 & 0 & 0 & 13.8 & 10.4 \\
\hline P3 & 153 & 0.081 & 0.021 & 0 & 0 & 1 & 0 & 16.2 & 10.4 \\
\hline P3 & 159 & 0.074 & 0.017 & 0 & 1 & 0 & 0 & 14.7 & 10.4 \\
\hline P3 & 191 & 0.078 & 0.019 & 0 & 0 & 1 & 0 & 15.6 & 10.6 \\
\hline P3 & 148 & 0.082 & 0.021 & 0 & 0 & 1 & 0 & 16.3 & 10.7 \\
\hline P3 & 150 & 0.078 & 0.019 & 0 & 0 & 1 & 0 & 15.5 & 10.7 \\
\hline P3 & 189 & 0.081 & 0.020 & 0 & 0 & 1 & 0 & 16.1 & 11.0 \\
\hline P3 & 161 & 0.061 & 0.011 & 0 & 1 & 0 & 0 & 12.1 & 12.4 \\
\hline P3 & Sums & $\rightarrow$ & 2.371 & 30 & 18 & 16 & 0 & & \\
\hline P4 & 48 & 0.000 & 0.000 & 1 & 0 & 0 & 0 & & 1.0 \\
\hline P4 & 49 & 0.000 & 0.000 & 1 & 0 & 0 & 0 & & 1.0 \\
\hline P4 & 50 & 0.000 & 0.000 & 1 & 0 & 0 & 0 & & 1.0 \\
\hline P4 & 51 & 0.000 & 0.000 & 1 & 0 & 0 & 0 & & 1.0 \\
\hline P4 & 61 & 0.000 & 0.000 & 1 & 0 & 0 & 0 & & 1.0 \\
\hline P4 & 62 & 0.000 & 0.000 & 1 & 0 & 0 & 0 & & 1.0 \\
\hline P4 & 63 & 0.000 & 0.000 & 1 & 0 & 0 & 0 & & 1.0 \\
\hline P4 & 64 & 0.000 & 0.000 & 1 & 0 & 0 & 0 & & 1.0 \\
\hline P4 & 65 & 0.000 & 0.000 & 1 & 0 & 0 & 0 & & 1.0 \\
\hline P4 & 66 & 0.000 & 0.000 & 1 & 0 & 0 & 0 & & 1.0 \\
\hline P4 & 67 & 0.000 & 0.000 & 1 & 0 & 0 & 0 & & 1.0 \\
\hline P4 & 68 & 0.000 & 0.000 & 1 & 0 & 0 & 0 & & 1.0 \\
\hline P4 & 69 & 0.000 & 0.000 & 1 & 0 & 0 & 0 & & 1.0 \\
\hline P4 & 70 & 0.000 & 0.000 & 1 & 0 & 0 & 0 & & 1.0 \\
\hline
\end{tabular}




\begin{tabular}{|c|c|c|c|c|c|c|c|c|c|}
\hline P4 & 71 & 0.000 & 0.000 & 1 & 0 & 0 & 0 & & 1.0 \\
\hline P4 & 72 & 0.000 & 0.000 & 1 & 0 & 0 & 0 & & 1.0 \\
\hline P4 & 73 & 0.000 & 0.000 & 1 & 0 & 0 & 0 & & 1.0 \\
\hline P4 & 74 & 0.000 & 0.000 & 1 & 0 & 0 & 0 & & 1.0 \\
\hline P4 & 75 & 0.000 & 0.000 & 1 & 0 & 0 & 0 & & 1.0 \\
\hline P4 & 76 & 0.000 & 0.000 & 1 & 0 & 0 & 0 & & 1.0 \\
\hline P4 & 77 & 0.000 & 0.000 & 1 & 0 & 0 & 0 & & 1.0 \\
\hline P4 & 78 & 0.000 & 0.000 & 1 & 0 & 0 & 0 & & 1.0 \\
\hline P4 & 79 & 0.000 & 0.000 & 1 & 0 & 0 & 0 & & 1.0 \\
\hline P4 & 80 & 0.000 & 0.000 & 1 & 0 & 0 & 0 & & 1.0 \\
\hline P4 & 81 & 0.000 & 0.000 & 1 & 0 & 0 & 0 & & 1.0 \\
\hline P4 & 6 & 0.000 & 0.000 & 1 & 0 & 0 & 0 & & 1.3 \\
\hline P4 & 25 & 0.077 & 0.018 & 0 & 0 & 1 & 0 & 15.3 & 2.3 \\
\hline P4 & 28 & 0.099 & 0.031 & 0 & 0 & 1 & 0 & 19.8 & 3.1 \\
\hline P4 & 7 & 0.098 & 0.030 & 0 & 0 & 1 & 0 & 19.5 & 3.5 \\
\hline P4 & 32 & 0.095 & 0.028 & 0 & 0 & 1 & 0 & 19.0 & 3.7 \\
\hline P4 & 19 & 0.103 & 0.033 & 0 & 0 & 0 & 1 & 20.6 & 3.9 \\
\hline P4 & 3 & 0.093 & 0.027 & 0 & 0 & 1 & 0 & 18.5 & 4.0 \\
\hline P4 & 18 & 0.090 & 0.025 & 0 & 0 & 1 & 0 & 18.0 & 4.0 \\
\hline P4 & 13 & 0.092 & 0.027 & 0 & 0 & 1 & 0 & 18.4 & 4.4 \\
\hline P4 & 14 & 0.075 & 0.017 & 0 & 1 & 0 & 0 & 14.9 & 4.5 \\
\hline P4 & 17 & 0.095 & 0.028 & 0 & 0 & 1 & 0 & 19.0 & 4.7 \\
\hline P4 & 11 & 0.090 & 0.025 & 0 & 0 & 1 & 0 & 18.0 & 4.9 \\
\hline P4 & 22 & 0.082 & 0.021 & 0 & 0 & 1 & 0 & 16.3 & 4.9 \\
\hline P4 & 44 & 0.100 & 0.031 & 0 & 0 & 1 & 0 & 19.9 & 4.9 \\
\hline P4 & 15 & 0.101 & 0.032 & 0 & 0 & 0 & 1 & 20.2 & 5.2 \\
\hline P4 & 27 & 0.085 & 0.022 & 0 & 0 & 1 & 0 & 16.9 & 5.3 \\
\hline P4 & 42 & 0.108 & 0.037 & 0 & 0 & 0 & 1 & 21.6 & 5.5 \\
\hline P4 & 47 & 0.107 & 0.036 & 0 & 0 & 0 & 1 & 21.4 & 5.5 \\
\hline P4 & 45 & 0.097 & 0.030 & 0 & 0 & 1 & 0 & 19.4 & 6.0 \\
\hline P4 & 52 & 0.072 & 0.016 & 0 & 1 & 0 & 0 & 14.3 & 6.3 \\
\hline P4 & 60 & 0.105 & 0.035 & 0 & 0 & 0 & 1 & 21.0 & 6.4 \\
\hline P4 & 2 & 0.098 & 0.030 & 0 & 0 & 1 & 0 & 19.5 & 6.5 \\
\hline P4 & 24 & 0.095 & 0.028 & 0 & 0 & 1 & 0 & 18.9 & 6.6 \\
\hline P4 & 41 & 0.075 & 0.017 & 0 & 1 & 0 & 0 & 14.9 & 6.7 \\
\hline
\end{tabular}




\begin{tabular}{|c|c|c|c|c|c|c|c|c|c|}
\hline P4 & 8 & 0.101 & 0.032 & 0 & 0 & 0 & 1 & 20.1 & 6.8 \\
\hline P4 & 10 & 0.089 & 0.025 & 0 & 0 & 1 & 0 & 17.7 & 6.9 \\
\hline P4 & 26 & 0.079 & 0.020 & 0 & 0 & 1 & 0 & 15.8 & 6.9 \\
\hline P4 & 29 & 0.071 & 0.016 & 0 & 1 & 0 & 0 & 14.2 & 6.9 \\
\hline P4 & 34 & 0.108 & 0.036 & 0 & 0 & 0 & 1 & 21.5 & 6.9 \\
\hline P4 & 31 & 0.081 & 0.021 & 0 & 0 & 1 & 0 & 16.2 & 7.0 \\
\hline P4 & 38 & 0.071 & 0.016 & 0 & 1 & 0 & 0 & 14.2 & 7.0 \\
\hline P4 & 56 & 0.073 & 0.017 & 0 & 1 & 0 & 0 & 14.5 & 7.1 \\
\hline P4 & 12 & 0.102 & 0.032 & 0 & 0 & 0 & 1 & 20.3 & 7.2 \\
\hline P4 & 23 & 0.085 & 0.022 & 0 & 0 & 1 & 0 & 16.9 & 7.3 \\
\hline P4 & 30 & 0.084 & 0.022 & 0 & 0 & 1 & 0 & 16.7 & 7.3 \\
\hline P4 & 53 & 0.074 & 0.017 & 0 & 1 & 0 & 0 & 14.8 & 7.3 \\
\hline P4 & 43 & 0.066 & 0.014 & 0 & 1 & 0 & 0 & 13.2 & 7.4 \\
\hline P4 & 4 & 0.068 & 0.014 & 0 & 1 & 0 & 0 & 13.5 & 7.6 \\
\hline P4 & 54 & 0.070 & 0.015 & 0 & 1 & 0 & 0 & 14.0 & 7.7 \\
\hline P4 & 55 & 0.080 & 0.020 & 0 & 0 & 1 & 0 & 15.9 & 7.9 \\
\hline P4 & 16 & 0.073 & 0.017 & 0 & 1 & 0 & 0 & 14.6 & 8.0 \\
\hline P4 & 40 & 0.085 & 0.022 & 0 & 0 & 1 & 0 & 16.9 & 8.0 \\
\hline P4 & 21 & 0.094 & 0.027 & 0 & 0 & 1 & 0 & 18.7 & 8.1 \\
\hline P4 & 35 & 0.071 & 0.016 & 0 & 1 & 0 & 0 & 14.2 & 8.3 \\
\hline P4 & 46 & 0.065 & 0.013 & 0 & 1 & 0 & 0 & 13.0 & 8.3 \\
\hline P4 & 20 & 0.083 & 0.022 & 0 & 0 & 1 & 0 & 16.6 & 8.4 \\
\hline P4 & 33 & 0.087 & 0.024 & 0 & 0 & 1 & 0 & 17.3 & 8.4 \\
\hline P4 & 37 & 0.070 & 0.015 & 0 & 1 & 0 & 0 & 13.9 & 8.5 \\
\hline P4 & 59 & 0.072 & 0.016 & 0 & 1 & 0 & 0 & 14.3 & 8.6 \\
\hline P4 & 39 & 0.077 & 0.018 & 0 & 0 & 1 & 0 & 15.3 & 8.7 \\
\hline P4 & 57 & 0.086 & 0.023 & 0 & 0 & 1 & 0 & 17.2 & 8.7 \\
\hline P4 & 58 & 0.075 & 0.018 & 0 & 0 & 1 & 0 & 15.0 & 8.9 \\
\hline P4 & 36 & 0.061 & 0.012 & 0 & 1 & 0 & 0 & 12.2 & 9.3 \\
\hline P4 & 9 & 0.071 & 0.016 & 0 & 1 & 0 & 0 & 14.2 & 9.4 \\
\hline P4 & Sums & $\rightarrow$ & 4.891 & 26 & 17 & 28 & 8 & & \\
\hline P5 & 115 & 0.000 & 0.000 & 1 & 0 & 0 & 0 & & 1.0 \\
\hline P5 & 116 & 0.000 & 0.000 & 1 & 0 & 0 & 0 & & 1.0 \\
\hline P5 & 117 & 0.000 & 0.000 & 1 & 0 & 0 & 0 & & 1.0 \\
\hline
\end{tabular}




\begin{tabular}{|c|c|c|c|c|c|c|c|c|}
\hline P5 & 118 & 0.000 & 0.000 & 1 & 0 & 0 & 0 & \\
\hline P5 & 119 & 0.000 & 0.000 & 1 & 0 & 0 & 0 & \\
\hline P5 & 120 & 0.000 & 0.000 & 1 & 0 & 0 & 0 & \\
\hline P5 & 121 & 0.000 & 0.000 & 1 & 0 & 0 & 0 & \\
\hline P5 & 122 & 0.000 & 0.000 & 1 & 0 & 0 & 0 & \\
\hline P5 & 123 & 0.000 & 0.000 & 1 & 0 & 0 & 0 & \\
\hline P5 & 124 & 0.000 & 0.000 & 1 & 0 & 0 & 0 & \\
\hline P5 & 125 & 0.000 & 0.000 & 1 & 0 & 0 & 0 & \\
\hline P5 & 126 & 0.000 & 0.000 & 1 & 0 & 0 & 0 & \\
\hline P5 & 127 & 0.000 & 0.000 & 1 & 0 & 0 & 0 & \\
\hline P5 & 128 & 0.000 & 0.000 & 1 & 0 & 0 & 0 & \\
\hline P5 & 129 & 0.000 & 0.000 & 1 & 0 & 0 & 0 & \\
\hline P5 & 130 & 0.000 & 0.000 & 1 & 0 & 0 & 0 & \\
\hline P5 & 131 & 0.000 & 0.000 & 1 & 0 & 0 & 0 & \\
\hline P5 & 132 & 0.000 & 0.000 & 1 & 0 & 0 & 0 & \\
\hline P5 & 133 & 0.000 & 0.000 & 1 & 0 & 0 & 0 & \\
\hline P5 & 134 & 0.000 & 0.000 & 1 & 0 & 0 & 0 & \\
\hline P5 & 135 & 0.000 & 0.000 & 1 & 0 & 0 & 0 & \\
\hline P5 & 136 & 0.000 & 0.000 & 1 & 0 & 0 & 0 & \\
\hline P5 & 137 & 0.000 & 0.000 & 1 & 0 & 0 & 0 & \\
\hline P5 & 138 & 0.000 & 0.000 & 1 & 0 & 0 & 0 & \\
\hline P5 & 139 & 0.000 & 0.000 & 1 & 0 & 0 & 0 & \\
\hline P5 & 140 & 0.000 & 0.000 & 1 & 0 & 0 & 0 & \\
\hline P5 & 141 & 0.000 & 0.000 & 1 & 0 & 0 & 0 & \\
\hline P5 & 142 & 0.000 & 0.000 & 1 & 0 & 0 & 0 & \\
\hline P5 & 143 & 0.000 & 0.000 & 1 & 0 & 0 & 0 & \\
\hline P5 & 144 & 0.000 & 0.000 & 1 & 0 & 0 & 0 & \\
\hline P5 & 145 & 0.000 & 0.000 & 1 & 0 & 0 & 0 & \\
\hline P5 & 146 & 0.000 & 0.000 & 1 & 0 & 0 & 0 & \\
\hline P5 & 147 & 0.000 & 0.000 & 1 & 0 & 0 & 0 & \\
\hline P5 & 148 & 0.000 & 0.000 & 1 & 0 & 0 & 0 & \\
\hline P5 & 86 & 0.080 & 0.020 & 0 & 0 & 1 & 0 & 15.9 \\
\hline P5 & 95 & 0.077 & 0.018 & 0 & 0 & 1 & 0 & 15.3 \\
\hline P5 & 102 & 0.074 & 0.017 & 0 & 1 & 0 & 0 & 14.8 \\
\hline P5 & 101 & 0.084 & 0.022 & 0 & 0 & 1 & 0 & 16.8 \\
\hline
\end{tabular}




\begin{tabular}{|c|c|c|c|c|c|c|c|c|c|}
\hline P5 & 84 & 0.073 & 0.017 & 0 & 1 & 0 & 0 & 14.5 & 7.0 \\
\hline P5 & 94 & 0.076 & 0.018 & 0 & 0 & 1 & 0 & 15.2 & 7.0 \\
\hline P5 & 88 & 0.082 & 0.021 & 0 & 0 & 1 & 0 & 16.3 & 7.1 \\
\hline P5 & 85 & 0.085 & 0.023 & 0 & 0 & 1 & 0 & 17.0 & 7.2 \\
\hline P5 & 107 & 0.090 & 0.025 & 0 & 0 & 1 & 0 & 17.9 & 7.2 \\
\hline P5 & 108 & 0.085 & 0.022 & 0 & 0 & 1 & 0 & 16.9 & 7.2 \\
\hline P5 & 92 & 0.075 & 0.017 & 0 & 1 & 0 & 0 & 14.9 & 7.4 \\
\hline P5 & 105 & 0.085 & 0.023 & 0 & 0 & 1 & 0 & 17.0 & 7.6 \\
\hline P5 & 87 & 0.065 & 0.013 & 0 & 1 & 0 & 0 & 13.0 & 7.7 \\
\hline P5 & 96 & 0.092 & 0.027 & 0 & 0 & 1 & 0 & 18.4 & 7.7 \\
\hline P5 & 103 & 0.077 & 0.018 & 0 & 0 & 1 & 0 & 15.3 & 8.0 \\
\hline P5 & 83 & 0.074 & 0.017 & 0 & 1 & 0 & 0 & 14.8 & 8.1 \\
\hline P5 & 97 & 0.085 & 0.023 & 0 & 0 & 1 & 0 & 17.0 & 8.3 \\
\hline P5 & 89 & 0.069 & 0.015 & 0 & 1 & 0 & 0 & 13.7 & 8.4 \\
\hline P5 & 104 & 0.085 & 0.022 & 0 & 0 & 1 & 0 & 16.9 & 8.9 \\
\hline P5 & 82 & 0.101 & 0.032 & 0 & 0 & 0 & 1 & 20.1 & 9.0 \\
\hline P5 & 106 & 0.082 & 0.021 & 0 & 0 & 1 & 0 & 16.3 & 12.9 \\
\hline P5 & Sums & $\rightarrow$ & 1.726 & 34 & 6 & 14 & 1 & & \\
\hline P6 & 152 & 0.000 & 0.000 & 1 & 0 & 0 & 0 & & 1.0 \\
\hline P6 & 154 & 0.000 & 0.000 & 1 & 0 & 0 & 0 & & 1.0 \\
\hline P6 & 155 & 0.000 & 0.000 & 1 & 0 & 0 & 0 & & 1.0 \\
\hline P6 & 156 & 0.000 & 0.000 & 1 & 0 & 0 & 0 & & 1.0 \\
\hline P6 & 159 & 0.000 & 0.000 & 1 & 0 & 0 & 0 & & 1.0 \\
\hline P6 & 160 & 0.000 & 0.000 & 1 & 0 & 0 & 0 & & 1.0 \\
\hline P6 & 161 & 0.000 & 0.000 & 1 & 0 & 0 & 0 & & 1.0 \\
\hline P6 & 164 & 0.000 & 0.000 & 1 & 0 & 0 & 0 & & 1.0 \\
\hline P6 & 165 & 0.000 & 0.000 & 1 & 0 & 0 & 0 & & 1.0 \\
\hline P6 & 166 & 0.000 & 0.000 & 1 & 0 & 0 & 0 & & 1.0 \\
\hline P6 & 167 & 0.000 & 0.000 & 1 & 0 & 0 & 0 & & 1.0 \\
\hline P6 & 171 & 0.000 & 0.000 & 1 & 0 & 0 & 0 & & 1.0 \\
\hline P6 & 175 & 0.000 & 0.000 & 1 & 0 & 0 & 0 & & 1.0 \\
\hline P6 & 176 & 0.000 & 0.000 & 1 & 0 & 0 & 0 & & 1.0 \\
\hline P6 & 177 & 0.000 & 0.000 & 1 & 0 & 0 & 0 & & 1.0 \\
\hline P6 & 178 & 0.000 & 0.000 & 1 & 0 & 0 & 0 & & 1.0 \\
\hline
\end{tabular}




\begin{tabular}{|c|c|c|c|c|c|c|c|c|c|}
\hline P6 & 181 & 0.000 & 0.000 & 1 & 0 & 0 & 0 & & 1.0 \\
\hline P6 & 182 & 0.000 & 0.000 & 1 & 0 & 0 & 0 & & 1.0 \\
\hline P6 & 183 & 0.000 & 0.000 & 1 & 0 & 0 & 0 & & 1.0 \\
\hline P6 & 184 & 0.000 & 0.000 & 1 & 0 & 0 & 0 & & 1.0 \\
\hline P6 & 190 & 0.000 & 0.000 & 1 & 0 & 0 & 0 & & 1.0 \\
\hline P6 & 191 & 0.000 & 0.000 & 1 & 0 & 0 & 0 & & 1.0 \\
\hline P6 & 193 & 0.000 & 0.000 & 1 & 0 & 0 & 0 & & 1.0 \\
\hline P6 & 198 & 0.000 & 0.000 & 1 & 0 & 0 & 0 & & 1.0 \\
\hline P6 & 201 & 0.000 & 0.000 & 1 & 0 & 0 & 0 & & 1.0 \\
\hline P6 & 196 & 0.102 & 0.032 & 0 & 0 & 0 & 1 & 20.3 & 4.5 \\
\hline P6 & 192 & 0.090 & 0.025 & 0 & 0 & 1 & 0 & 17.9 & 5.1 \\
\hline P6 & 157 & 0.100 & 0.031 & 0 & 0 & 0 & 1 & 20.0 & 5.3 \\
\hline P6 & 199 & 0.067 & 0.014 & 0 & 1 & 0 & 0 & 13.3 & 6.0 \\
\hline P6 & 162 & 0.084 & 0.022 & 0 & 0 & 1 & 0 & 16.7 & 6.3 \\
\hline P6 & 172 & 0.092 & 0.026 & 0 & 0 & 1 & 0 & 18.3 & 6.5 \\
\hline P6 & 151 & 0.077 & 0.019 & 0 & 0 & 1 & 0 & 15.4 & 6.6 \\
\hline P6 & 170 & 0.083 & 0.022 & 0 & 0 & 1 & 0 & 16.6 & 6.8 \\
\hline P6 & 174 & 0.086 & 0.023 & 0 & 0 & 1 & 0 & 17.1 & 6.8 \\
\hline P6 & 188 & 0.088 & 0.024 & 0 & 0 & 1 & 0 & 17.5 & 6.9 \\
\hline P6 & 189 & 0.087 & 0.024 & 0 & 0 & 1 & 0 & 17.4 & 7.0 \\
\hline P6 & 173 & 0.108 & 0.036 & 0 & 0 & 0 & 1 & 21.5 & 7.1 \\
\hline P6 & 194 & 0.093 & 0.027 & 0 & 0 & 1 & 0 & 18.5 & 7.1 \\
\hline P6 & 163 & 0.076 & 0.018 & 0 & 0 & 1 & 0 & 15.2 & 7.5 \\
\hline P6 & 200 & 0.110 & 0.038 & 0 & 0 & 0 & 1 & 22.0 & 7.5 \\
\hline P6 & 186 & 0.089 & 0.025 & 0 & 0 & 1 & 0 & 17.7 & 7.6 \\
\hline P6 & 149 & 0.092 & 0.026 & 0 & 0 & 1 & 0 & 18.3 & 7.7 \\
\hline P6 & 153 & 0.092 & 0.027 & 0 & 0 & 1 & 0 & 18.4 & 7.7 \\
\hline P6 & 179 & 0.078 & 0.019 & 0 & 0 & 1 & 0 & 15.5 & 7.7 \\
\hline P6 & 197 & 0.100 & 0.031 & 0 & 0 & 0 & 1 & 20.0 & 7.7 \\
\hline P6 & 187 & 0.114 & 0.041 & 0 & 0 & 0 & 1 & 22.8 & 8.3 \\
\hline P6 & 15 & 0.078 & 0.019 & 0 & 0 & 1 & 0 & 15.6 & 8.7 \\
\hline P6 & 180 & 0.119 & 0.044 & 0 & 0 & 0 & 1 & 23.7 & 8.8 \\
\hline P6 & 158 & 0.075 & 0.018 & 0 & 0 & 1 & 0 & 15.0 & 9.7 \\
\hline P6 & Sums & $\rightarrow$ & 2.524 & 25 & 1 & 16 & 7 & & \\
\hline
\end{tabular}




\section{Table A.3}

GPS waypoints of palm stems converted from decimal degrees

\begin{tabular}{|c|c|c|c|c|c|c|}
\hline Plot & $\begin{array}{l}\text { GPS } \\
\text { pt\# }\end{array}$ & $\begin{array}{c}Y \\
\text { (ddm) }\end{array}$ & $\begin{array}{c}X \\
(\mathrm{ddm})\end{array}$ & $\begin{array}{l}\text { Y_Met } \\
\text { (meters) }\end{array}$ & $\begin{array}{l}\text { X_Met } \\
\text { (meters) }\end{array}$ & $\begin{array}{l}\text { Field } \\
\text { Notes }\end{array}$ \\
\hline $\mathrm{P} 1$ & 55 & 20.088100 & 58.283783 & 2223838.6 & 6099226.2 & NW quad,71m \\
\hline P1 & 62 & 20.088400 & 58.283550 & 2223871.8 & 6099201.8 & NW quad, $71 \mathrm{~m}$ \\
\hline $\mathrm{P} 1$ & 54 & 20.088117 & 58.283750 & 2223840.5 & 6099222.7 & SW \\
\hline $\mathrm{P} 1$ & 52 & 20.088267 & 58.283700 & 2223857.5 & 6099217.4 & NW quad, $71 \mathrm{~m}$ \\
\hline $\mathrm{P} 1$ & 63 & 20.088283 & 58.283717 & 2223858.9 & 6099219.2 & SE \\
\hline $\mathrm{P} 1$ & 53 & 20.088267 & 58.283733 & 2223857.1 & 6099220.9 & NW quad, $71 \mathrm{~m}$ \\
\hline $\mathrm{P} 1$ & 61 & 20.088333 & 58.283517 & 2223864.4 & 6099198.3 & NW quad, $71 \mathrm{~m}$ \\
\hline $\mathrm{P} 1$ & 50 & 20.088233 & 58.283667 & 2223853.5 & 6099214 & SW \\
\hline $\mathrm{P} 1$ & 51 & 20.088233 & 58.283667 & 2223853.4 & 6099214 & $\mathrm{NW}$,too scaled for $\mathrm{dbh}$ \\
\hline P1 & 64 & 20.088267 & 58.283700 & 2223857.1 & 6099217.4 & $\begin{array}{l}\text { SE quad,too scaled for } \\
\text { dbh }\end{array}$ \\
\hline P1 & 56 & 20.088000 & 58.283850 & 2223827.5 & 6099233.1 & $\begin{array}{l}\text { NE quad,too scaled for } \\
\text { dbh }\end{array}$ \\
\hline $\mathrm{P} 1$ & 60 & 20.088333 & 58.283433 & 2223864.4 & 6099189.5 & $\mathrm{NE}$, too scaled for dbh \\
\hline $\mathrm{P} 1$ & 57 & 20.088133 & 58.283483 & 2223842.3 & 6099194.8 & internal xylem burned \\
\hline $\mathrm{P} 1$ & 59 & 20.088133 & 58.283417 & 2223842.3 & 6099187.8 & \\
\hline P1 & 28 & 20.088317 & 58.283550 & 2223862.6 & 6099201.8 & NE, No DBH, too branchy \\
\hline P1 & 32 & 20.088367 & 58.283733 & 2223868.1 & 6099220.9 & NW quad \\
\hline $\mathrm{P} 1$ & 58 & 20.088167 & 58.283467 & 2223846 & 6099193 & \\
\hline P1 & 49 & 20.088200 & 58.283683 & 2223849.7 & 6099215.7 & \\
\hline $\mathrm{P} 1$ & 11 & 20.088050 & 58.283500 & 2223833.1 & 6099196.5 & curved stem \\
\hline P1 & 14 & 20.088250 & 58.283433 & 2223855.2 & 6099189.5 & \\
\hline P1 & 24 & 20.088383 & 58.283467 & 2223870 & 6099193 & \\
\hline P1 & 29 & 20.088350 & 58.283617 & 2223866.3 & 6099208.7 & overstory \\
\hline $\mathrm{P} 1$ & 34 & 20.088283 & 58.283700 & 2223858.9 & 6099217.4 & \\
\hline P1 & 38 & 20.088200 & 58.283783 & 2223849.7 & 6099226.2 & \\
\hline P1 & 45 & 20.088200 & 58.283700 & 2223849.7 & 6099217.4 & \\
\hline P1 & 46 & 20.088167 & 58.283683 & 2223846 & 6099215.7 & \\
\hline P1 & 7 & 20.088167 & 58.283550 & 2223846 & 6099201.8 & day 2 finish NE quad \\
\hline P1 & 12 & 20.088117 & 58.283483 & 2223840.5 & 6099194.8 & \\
\hline
\end{tabular}




\begin{tabular}{|c|c|c|c|c|c|c|}
\hline $\mathrm{P} 1$ & 13 & 20.088217 & 58.283450 & 2223851.5 & 6099191.3 & \\
\hline P1 & 16 & 20.088350 & 58.283367 & 2223866.3 & 6099182.6 & intermediate story \\
\hline $\mathrm{P} 1$ & 18 & 20.088333 & 58.283433 & 2223864.5 & 6099189.5 & \\
\hline $\mathrm{P} 1$ & 19 & 20.088350 & 58.283433 & 2223866.3 & 6099189.5 & \\
\hline P1 & 20 & 20.088367 & 58.283417 & 2223867.5 & 6099187.8 & \\
\hline $\mathrm{P} 1$ & 23 & 20.088367 & 58.283467 & 2223868.1 & 6099193 & \\
\hline $\mathrm{P} 1$ & 25 & 20.088317 & 58.283500 & 2223862.6 & 6099196.5 & SW Quad \\
\hline P1 & 26 & 20.088300 & 58.283500 & 2223860.8 & 6099196.5 & \\
\hline $\mathrm{P} 1$ & 27 & 20.088267 & 58.283550 & 2223857.1 & 6099201.8 & \\
\hline $\mathrm{P} 1$ & 30 & 20.088350 & 58.283650 & 2223866.3 & 6099212.2 & curved at base of stem \\
\hline $\mathrm{P} 1$ & 33 & 20.088317 & 58.283683 & 2223862.6 & 6099215.7 & insect damg; dwd \\
\hline $\mathrm{P} 1$ & 39 & 20.088151 & 58.283810 & 2223844.3 & 6099229 & right on west edge? \\
\hline $\mathrm{P} 1$ & 41 & 20.088100 & 58.283767 & 2223838.6 & 6099224.4 & ctr guideline \\
\hline P1 & 43 & 20.088150 & 58.283900 & 2223844.1 & 6099238.4 & obsev, photo \#, diseases \\
\hline $\mathrm{P} 1$ & 44 & 20.088183 & 58.283700 & 2223847.8 & 6099217.4 & \\
\hline P1 & 3 & 20.088267 & 58.283600 & 2223857.1 & 6099207 & \\
\hline P1 & 6 & 20.088167 & 58.283600 & 2223846 & 6099207 & DWD \\
\hline P1 & 15 & 20.088250 & 58.283400 & 2223855.2 & 6099186.1 & \\
\hline P1 & 17 & 20.088300 & 58.283417 & 2223860.8 & 6099187.8 & \\
\hline P1 & 31 & 20.088383 & 58.283667 & 2223870 & 6099214 & \\
\hline P1 & 35 & 20.088217 & 58.283683 & 2223851.5 & 6099215.7 & no leaves. Dead \\
\hline P1 & 36 & 20.088217 & 58.283750 & 2223851.5 & 6099222.7 & \\
\hline P1 & 37 & 20.088200 & 58.283750 & 2223849.7 & 6099222.7 & \\
\hline P1 & 47 & 20.088150 & 58.283683 & 2223844.1 & 6099215.7 & \\
\hline P1 & 48 & 20.088167 & 58.283717 & 2223846 & 6099219.2 & \\
\hline P1 & 5 & 20.088233 & 58.283583 & 2223853.4 & 6099205.2 & \\
\hline P1 & 8 & 20.088100 & 58.283550 & 2223838.6 & 6099201.8 & \\
\hline P1 & 9 & 20.088083 & 58.283583 & 2223836.8 & 6099205.2 & intermediate story \\
\hline P1 & 21 & 20.088367 & 58.283417 & 2223868.1 & 6099187.8 & \\
\hline P1 & 40 & 20.088150 & 58.283800 & 2223844.1 & 6099227.9 & intermediate story \\
\hline P1 & 42 & 20.088067 & 58.283833 & 2223834.9 & 6099231.4 & shoots \\
\hline P1 & 22 & 20.088367 & 58.283450 & 2223868.1 & 6099191.3 & \\
\hline P1 & 4 & 20.088250 & 58.283583 & 2223855.2 & 6099205.2 & \\
\hline P1 & 10 & 20.088067 & 58.283633 & 2223834.9 & 6099210.5 & \\
\hline
\end{tabular}




\begin{tabular}{|c|c|c|c|c|c|c|}
\hline P2 & 107 & 20.088467 & 58.276183 & 2223879.2 & 6098430.9 & \\
\hline P2 & 108 & 20.088433 & 58.276150 & 2223875.5 & 6098427.4 & DWD \\
\hline P2 & 104 & 20.088500 & 58.276100 & 2223882.9 & 6098422.1 & \\
\hline P2 & 113 & 20.088400 & 58.276133 & 2223871.5 & 6098425.6 & DWD, $\mathrm{DBH}$ on petioles \\
\hline P2 & 97 & 20.088417 & 58.276167 & 2223873.4 & 6098429.1 & \\
\hline P2 & 98 & 20.088650 & 58.276267 & 2223899.5 & 6098439.6 & $\begin{array}{l}\text { DWD, low petioles on } \\
\text { stem }\end{array}$ \\
\hline P2 & 114 & 20.088417 & 58.276233 & 2223873.7 & 6098436.1 & $10 \times 10 m$ of $11,1 \mathrm{~m}$ regen \\
\hline P2 & 100 & 20.088583 & 58.276167 & 2223892.1 & 6098429.1 & \\
\hline P2 & 106 & 20.088450 & 58.276133 & 2223877.4 & 6098425.6 & \\
\hline P2 & 112 & 20.088400 & 58.276133 & 2223872 & 6098425.6 & \\
\hline P2 & 111 & 20.088417 & 58.276167 & 2223874 & 6098429.1 & \\
\hline P2 & 95 & 20.088583 & 58.276417 & 2223892.1 & 6098455.3 & $45^{\circ}$ stem $1.9 \mathrm{~m}$ long \\
\hline P2 & 105 & 20.088500 & 58.276050 & 2223882.9 & 6098416.9 & DWD \\
\hline P2 & 110 & 20.088450 & 58.276183 & 2223877.4 & 6098430.9 & \\
\hline $\mathrm{P} 2$ & 85 & 20.088433 & 58.276467 & 2223875.5 & 6098460.5 & No leaves,dead? \\
\hline $\mathrm{P} 2$ & 120 & 20.088483 & 58.276233 & 2223881 & 6098436.1 & no leaves \\
\hline $\mathrm{P} 2$ & 73 & 20.088333 & 58.276367 & 2223864.4 & 6098450 & \\
\hline $\mathrm{P} 2$ & 89 & 20.088700 & 58.276467 & 2223905 & 6098460.5 & \\
\hline $\mathrm{P} 2$ & 118 & 20.088367 & 58.276233 & 2223868.1 & 6098436.1 & \\
\hline $\mathrm{P} 2$ & 77 & 20.088300 & 58.276317 & 2223860.8 & 6098444.8 & no leaves \\
\hline $\mathrm{P} 2$ & 80 & 20.088283 & 58.276400 & 2223858.9 & 6098453.5 & DWD \\
\hline $\mathrm{P} 2$ & 119 & 20.088433 & 58.276250 & 2223875.5 & 6098437.8 & \\
\hline $\mathrm{P} 2$ & 122 & 20.088250 & 58.276183 & 2223855.2 & 6098430.9 & \\
\hline $\mathrm{P} 2$ & 70 & 20.088400 & 58.276400 & 2223871.8 & 6098453.5 & insect holes \\
\hline $\mathrm{P} 2$ & 92 & 20.088700 & 58.276350 & 2223905 & 6098448.3 & \\
\hline $\mathrm{P} 2$ & 117 & 20.088350 & 58.276217 & 2223866.3 & 6098434.3 & \\
\hline $\mathrm{P} 2$ & 90 & 20.088633 & 58.276417 & 2223897.7 & 6098455.3 & insect holes, moving east \\
\hline $\mathrm{P} 2$ & 71 & 20.088350 & 58.276417 & 2223866.3 & 6098455.3 & DWD \\
\hline $\mathrm{P} 2$ & 96 & 20.088583 & 58.276367 & 2223892.1 & 6098450 & \\
\hline $\mathrm{P} 2$ & 91 & 20.088700 & 58.276383 & 2223905 & 6098451.8 & \\
\hline $\mathrm{P} 2$ & 99 & 20.088600 & 58.276267 & 2223894 & 6098439.6 & \\
\hline $\mathrm{P} 2$ & 109 & 20.088417 & 58.276150 & 2223873.7 & 6098427.4 & DWD \\
\hline
\end{tabular}




\begin{tabular}{|c|c|c|c|c|c|c|}
\hline P2 & 83 & 20.088367 & 58.276483 & 2223868.1 & 6098462.2 & \\
\hline P2 & 101 & 20.088633 & 58.276133 & 2223897.7 & 6098425.6 & DWD \\
\hline P2 & 76 & 20.088300 & 58.276333 & 2223860.8 & 6098446.5 & NW quad \\
\hline P2 & 102 & 20.088583 & 58.276050 & 2223892.1 & 6098416.9 & \\
\hline P2 & 66 & 20.088433 & 58.276317 & 2223875.5 & 6098444.8 & \\
\hline P2 & 72 & 20.088350 & 58.276400 & 2223866.3 & 6098453.5 & insect holes \\
\hline P2 & 81 & 20.088317 & 58.276450 & 2223862.6 & 6098458.8 & insect holes \\
\hline P2 & 88 & 20.088600 & 58.276500 & 2223894 & 6098464 & \\
\hline P2 & 103 & 20.088533 & 58.276083 & 2223886.6 & 6098420.4 & DWD \\
\hline P2 & 69 & 20.088350 & 58.276383 & 2223866.3 & 6098451.8 & w/in2m of waypt 93 \\
\hline P2 & 93 & 20.088650 & 58.276417 & 2223899.5 & 6098455.3 & DWD \\
\hline P2 & 94 & 20.088617 & 58.276417 & 2223895.8 & 6098455.3 & curved \\
\hline P2 & 87 & 20.088483 & 58.276467 & 2223881 & 6098460.5 & \\
\hline P2 & 79 & 20.088267 & 58.276250 & 2223857.1 & 6098437.8 & \\
\hline P2 & 121 & 20.088267 & 58.276150 & 2223857.1 & 6098427.4 & \\
\hline P2 & 123 & 20.088350 & 58.276267 & 2223866.3 & 6098439.6 & curved \\
\hline P2 & 74 & 20.088317 & 58.276350 & 2223862.6 & 6098448.3 & \\
\hline P2 & 67 & 20.088400 & 58.276333 & 2223871.8 & 6098446.5 & \\
\hline P2 & 68 & 20.088383 & 58.276350 & 2223870 & 6098448.3 & \\
\hline P2 & 75 & 20.088333 & 58.276383 & 2223864.4 & 6098451.8 & \\
\hline P2 & 78 & 20.088283 & 58.276317 & 2223858.9 & 6098444.8 & \\
\hline P2 & 116 & 20.088400 & 58.276233 & 2223871.8 & 6098436.1 & on West edge,DWD \\
\hline P3 & 133 & 20.089117 & 58.275867 & 2223951.2 & 6098397.7 & DWD \\
\hline P3 & 138 & 20.089067 & 58.275733 & 2223946 & 6098383.8 & \\
\hline P3 & 140 & 20.089083 & 58.275717 & 2223948 & 6098382 & \\
\hline P3 & 146 & 20.089033 & 58.275533 & 2223941.9 & 6098362.8 & \\
\hline P3 & 152 & 20.089033 & 58.275417 & 2223941.5 & 6098350.6 & \\
\hline P3 & 158 & 20.089283 & 58.275433 & 2223969.6 & 6098352.4 & \\
\hline P3 & 163 & 20.089200 & 58.275533 & 2223960.4 & 6098362.8 & \\
\hline P3 & 172 & 20.089367 & 58.275550 & 2223978.8 & 6098364.6 & \\
\hline P3 & 175 & 20.089333 & 58.275550 & 2223975.6 & 6098364.6 & \\
\hline P3 & 178 & 20.089367 & 58.275650 & 2223978.8 & 6098375 & \\
\hline P3 & 160 & 20.089233 & 58.275500 & 2223964.1 & 6098359.3 & DWD \\
\hline
\end{tabular}




\begin{tabular}{|c|c|c|c|c|c|c|}
\hline P3 & 170 & 20.089333 & 58.275400 & 2223975.1 & 6098348.9 & \\
\hline P3 & 176 & 20.089300 & 58.275550 & 2223971.5 & 6098364.6 & near center \\
\hline P3 & 141 & 20.089050 & 58.275650 & 2223943.8 & 6098375 & \\
\hline P3 & 127 & 20.089183 & 58.275617 & 2223958.5 & 6098371.6 & \\
\hline P3 & 166 & 20.089250 & 58.275583 & 2223965.9 & 6098368.1 & \\
\hline P3 & 167 & 20.089283 & 58.275467 & 2223969.6 & 6098355.9 & \\
\hline P3 & 139 & 20.089067 & 58.275733 & 2223945.6 & 6098383.8 & \\
\hline P3 & 147 & 20.089017 & 58.275500 & 2223940.1 & 6098359.3 & \\
\hline P3 & 165 & 20.089250 & 58.275600 & 2223965.9 & 6098369.8 & \\
\hline P3 & 177 & 20.089367 & 58.275633 & 2223978.8 & 6098373.3 & \\
\hline P3 & 132 & 20.089083 & 58.275717 & 2223948.5 & 6098382 & \\
\hline P3 & 174 & 20.089333 & 58.275550 & 2223975.1 & 6098364.6 & \\
\hline P3 & 173 & 20.089367 & 58.275550 & 2223978.8 & 6098365 & \\
\hline P3 & 142 & 20.089083 & 58.275633 & 2223947.5 & 6098373.3 & \\
\hline P3 & 182 & 20.089283 & 58.275800 & 2223969.6 & 6098390.7 & \\
\hline P3 & 187 & 20.089300 & 58.275767 & 2223971.5 & 6098387.3 & \\
\hline P3 & 135 & 20.089017 & 58.275850 & 2223940.1 & 6098396 & \\
\hline P3 & 190 & 20.089350 & 58.275833 & 2223977 & 6098394.2 & \\
\hline P3 & 168 & 20.089283 & 58.275500 & 2223969.6 & 6098359.3 & \\
\hline P3 & 184 & 20.089250 & 58.275767 & 2223965.9 & 6098387.3 & \\
\hline P3 & 144 & 20.089150 & 58.275700 & 2223954.9 & 6098380.3 & \\
\hline P3 & 134 & 20.089033 & 58.275850 & 2223942 & 6098396 & \\
\hline P3 & 171 & 20.089367 & 58.275483 & 2223978.8 & 6098357.6 & \\
\hline P3 & 143 & 20.089100 & 58.275650 & 2223949.3 & 6098375 & \\
\hline P3 & 129 & 20.089183 & 58.275733 & 2223958.5 & 6098383.8 & \\
\hline P3 & 164 & 20.089267 & 58.275583 & 2223967.8 & 6098368.1 & \\
\hline P3 & 169 & 20.089300 & 58.275417 & 2223971.5 & 6098350.6 & no leaves \\
\hline P3 & 154 & 20.089133 & 58.275467 & 2223953 & 6098355.9 & \\
\hline P3 & 151 & 20.089033 & 58.275417 & 2223941.9 & 6098350.6 & \\
\hline P3 & 181 & 20.089267 & 58.275767 & 2223967.8 & 6098387.3 & DWD \\
\hline P3 & 185 & 20.089267 & 58.275800 & 2223967.8 & 6098390.7 & \\
\hline P3 & 186 & 20.089267 & 58.275783 & 2223967.8 & 6098389 & \\
\hline P3 & 137 & 20.089017 & 58.275767 & 2223940.1 & 6098387.3 & SW corner \\
\hline P3 & 157 & 20.089283 & 58.275400 & 2223969.6 & 6098348.9 & \\
\hline P3 & 179 & 20.089300 & 58.275650 & 2223971.5 & 6098375 & \\
\hline
\end{tabular}




\begin{tabular}{|c|c|c|c|c|c|c|}
\hline P3 & 183 & 20.089267 & 58.275717 & 2223967.8 & 6098382 & \\
\hline P3 & 134 & 20.089150 & 58.275733 & 2223954.9 & 6098383.8 & \\
\hline P3 & 180 & 20.089317 & 58.275750 & 2223973.3 & 6098385.5 & \\
\hline P3 & 149 & 20.089100 & 58.275500 & 2223949.3 & 6098359.3 & DWD \\
\hline P3 & 155 & 20.089167 & 58.275433 & 2223956.7 & 6098352.4 & DWD \\
\hline P3 & 156 & 20.089183 & 58.275450 & 2223958.5 & 6098354.1 & Moving $\mathrm{E}, \|$ to scrub patch \\
\hline P3 & 130 & 20.089217 & 58.275783 & 2223962.2 & 6098389 & \\
\hline P3 & 162 & 20.089200 & 58.275550 & 2223960.4 & 6098364.6 & \\
\hline P3 & 188 & 20.089250 & 58.275850 & 2223965.9 & 6098396 & insect holes \\
\hline P3 & 136 & 20.089033 & 58.275783 & 2223942.5 & 6098389 & no leaves \\
\hline P3 & 145 & 20.089050 & 58.275550 & 2223943.8 & 6098364.6 & \\
\hline P3 & 153 & 20.089117 & 58.275467 & 2223951.2 & 6098355.9 & \\
\hline P3 & 159 & 20.089217 & 58.275500 & 2223962.2 & 6098359.3 & \\
\hline P3 & 191 & 20.089317 & 58.275783 & 2223973.3 & 6098389 & moving south \\
\hline P3 & 148 & 20.089067 & 58.275500 & 2223945.6 & 6098359.3 & \\
\hline P3 & 150 & 20.089083 & 58.275400 & 2223947.5 & 6098348.9 & \\
\hline P3 & 189 & 20.089333 & 58.275817 & 2223975.1 & 6098392.5 & \\
\hline P3 & 161 & 20.089217 & 58.275517 & 2223962.2 & 6098361.1 & \\
\hline P4 & 48 & 20.067420 & 58.287680 & 2221549.2 & 6099633.9 & \\
\hline P4 & 49 & 20.067430 & 58.287730 & 2221550.4 & 6099639.2 & \\
\hline P4 & 50 & 20.067420 & 58.287740 & 2221549.2 & 6099640.2 & \\
\hline P4 & 51 & 20.067510 & 58.287750 & 2221559.2 & 6099641.3 & \\
\hline P4 & 61 & 20.067570 & 58.288080 & 2221565.9 & 6099675.8 & \\
\hline P4 & 62 & 20.067540 & 58.288040 & 2221562.5 & 6099671.6 & \\
\hline P4 & 63 & 20.067520 & 58.288080 & 2221560.3 & 6099675.8 & \\
\hline P4 & 64 & 20.067500 & 58.288060 & 2221558.1 & 6099673.7 & \\
\hline P4 & 65 & 20.067490 & 58.288060 & 2221557 & 6099673.7 & \\
\hline P4 & 66 & 20.067470 & 58.288060 & 2221554.8 & 6099673.7 & \\
\hline P4 & 67 & 20.067490 & 58.288080 & 2221557 & 6099675.8 & \\
\hline P4 & 68 & 20.067490 & 58.288080 & 2221557.5 & 6099675.8 & \\
\hline P4 & 69 & 20.067470 & 58.288120 & 2221554.8 & 6099680 & \\
\hline P4 & 70 & 20.067350 & 58.288100 & 2221541.5 & 6099677.9 & \\
\hline P4 & 71 & 20.067390 & 58.288050 & 2221545.9 & 6099672.7 & \\
\hline
\end{tabular}




\begin{tabular}{|c|c|c|c|c|c|c|}
\hline P4 & 72 & 20.067370 & 58.288050 & 2221543.7 & 6099672.7 & \\
\hline P4 & 73 & 20.067300 & 58.288070 & 2221536 & 6099674.8 & \\
\hline P4 & 74 & 20.067300 & 58.288020 & 2221536 & 6099669.5 & \\
\hline P4 & 75 & 20.067220 & 58.287780 & 2221527.1 & 6099644.4 & \\
\hline P4 & 76 & 20.067200 & 58.287670 & 2221524.9 & 6099632.9 & \\
\hline P4 & 77 & 20.067360 & 58.287750 & 2221542.6 & 6099641.3 & \\
\hline P4 & 78 & 20.067450 & 58.287750 & 2221552.6 & 6099641.3 & \\
\hline P4 & 79 & 20.067470 & 58.287760 & 2221554.8 & 6099642.3 & \\
\hline P4 & 80 & 20.067490 & 58.287760 & 2221557 & 6099642.3 & \\
\hline P4 & 81 & 20.067550 & 58.287780 & 2221563.6 & 6099644.4 & \\
\hline P4 & 6 & 20.067360 & 58.288050 & 2221542.6 & 6099672.7 & \\
\hline P4 & 25 & 20.067283 & 58.287817 & 2221534.1 & 6099648.2 & no leaves on palm $2 \mathrm{~m}$ NE \\
\hline P4 & 28 & 20.067267 & 58.287817 & 2221532.3 & 6099648.5 & \\
\hline P4 & 7 & 20.067450 & 58.288050 & 2221552.6 & 6099672.7 & \\
\hline P4 & 32 & 20.067267 & 58.287717 & 2221532.3 & 6099637.8 & \\
\hline P4 & 19 & 20.067183 & 58.287983 & 2221523 & 6099665.7 & insect damage \\
\hline P4 & 3 & 20.067367 & 58.288067 & 2221543.3 & 6099674.4 & \\
\hline P4 & 18 & 20.067217 & 58.288033 & 2221526.7 & 6099670.9 & \\
\hline P4 & 13 & 20.067250 & 58.287967 & 2221530.4 & 6099663.9 & \\
\hline P4 & 14 & 20.067267 & 58.288017 & 2221532.3 & 6099669.2 & \\
\hline P4 & 17 & 20.067267 & 58.288000 & 2221532.3 & 6099667.4 & \\
\hline P4 & 11 & 20.067300 & 58.288167 & 2221536 & 6099684.9 & \\
\hline P4 & 22 & 20.067267 & 58.287883 & 2221532.3 & 6099655.2 & \\
\hline P4 & 44 & 20.067400 & 58.287683 & 2221547 & 6099634.3 & \\
\hline P4 & 15 & 20.067300 & 58.287883 & 2221536 & 6099655.2 & \\
\hline P4 & 27 & 20.067267 & 58.287817 & 2221532.5 & 6099648.2 & \\
\hline P4 & 42 & 20.067400 & 58.287883 & 2221547 & 6099655.2 & no leaves \\
\hline P4 & 47 & 20.067483 & 58.287683 & 2221556.3 & 6099634.3 & extreme burn damage \\
\hline P4 & 45 & 20.067400 & 58.287650 & 2221547 & 6099630.8 & \\
\hline P4 & 52 & 20.067583 & 58.287800 & 2221567.3 & 6099646.5 & Northwest quad \\
\hline P4 & 60 & 20.067550 & 58.288050 & 2221563.6 & 6099672.7 & \\
\hline P4 & 2 & 20.067383 & 58.287967 & 2221545.2 & 6099663.9 & \\
\hline P4 & 24 & 20.067183 & 58.287833 & 2221523 & 6099650 & no leaves \\
\hline P4 & 41 & 20.067417 & 58.287867 & 2221548.9 & 6099653.5 & \\
\hline P4 & 8 & 20.067417 & 58.288067 & 2221548.9 & 6099674.4 & \\
\hline
\end{tabular}




\begin{tabular}{|c|c|c|c|c|c|c|}
\hline P4 & 10 & 20.067333 & 58.288150 & 2221539.7 & 6099683.1 & no leaves \\
\hline P4 & 26 & 20.067267 & 58.287817 & 2221532 & 6099648 & \\
\hline P4 & 29 & 20.067267 & 58.287767 & 2221532.3 & 6099643 & \\
\hline P4 & 34 & 20.067283 & 58.287650 & 2221534.1 & 6099630.5 & \\
\hline P4 & 31 & 20.067233 & 58.287750 & 2221528.6 & 6099641.3 & \\
\hline P4 & 38 & 20.067367 & 58.287767 & 2221543.3 & 6099643 & \\
\hline P4 & 56 & 20.067500 & 58.288000 & 2221558.1 & 6099667.4 & \\
\hline P4 & 12 & 20.067317 & 58.288033 & 2221537.8 & 6099670.9 & \\
\hline P4 & 23 & 20.067250 & 58.287933 & 2221530.4 & 6099660.5 & \\
\hline P4 & 30 & 20.067217 & 58.287750 & 2221526.7 & 6099641.3 & \\
\hline P4 & 53 & 20.067533 & 58.287967 & 2221561.8 & 6099663.9 & \\
\hline P4 & 43 & 20.067400 & 58.287700 & 2221547 & 6099636 & \\
\hline P4 & 4 & 20.067317 & 58.288067 & 2221537.8 & 6099674.4 & \\
\hline P4 & 54 & 20.067550 & 58.288017 & 2221563.6 & 6099669.2 & \\
\hline P4 & 55 & 20.067567 & 58.287883 & 2221565.5 & 6099655.2 & Southeast quad \\
\hline P4 & 16 & 20.067250 & 58.288000 & 2221530.4 & 6099667.4 & \\
\hline P4 & 40 & 20.067400 & 58.287833 & 2221547 & 6099650 & \\
\hline P4 & 21 & 20.067333 & 58.287950 & 2221539.7 & 6099662.2 & \\
\hline P4 & 35 & 20.067350 & 58.287683 & 2221541.5 & 6099634.3 & Northeast quad \\
\hline P4 & 46 & 20.067433 & 58.287650 & 2221550.7 & 6099630.8 & \\
\hline P4 & 20 & 20.067350 & 58.287900 & 2221541.5 & 6099657 & \\
\hline P4 & 33 & 20.067283 & 58.287650 & 2221534.1 & 6099631 & \\
\hline P4 & 37 & 20.067350 & 58.287733 & 2221541.5 & 6099639.5 & \\
\hline P4 & 59 & 20.067617 & 58.287983 & 2221571 & 6099665.7 & Southwest quad \\
\hline P4 & 39 & 20.067367 & 58.287800 & 2221543.3 & 6099646.5 & \\
\hline P4 & 57 & 20.067567 & 58.288000 & 2221565.5 & 6099667.4 & Northeast quad \\
\hline P4 & 58 & 20.067617 & 58.288000 & 2221571 & 6099667.4 & \\
\hline P4 & 36 & 20.067350 & 58.287733 & 2221542 & 6099640 & \\
\hline P4 & 9 & 20.067450 & 58.288167 & 2221552.6 & 6099684.9 & \\
\hline P5 & 115 & 20.067583 & 58.286383 & 2221567.3 & 6099498.3 & \\
\hline P5 & 116 & 20.067590 & 58.286360 & 2221568.1 & 6099495.8 & \\
\hline P5 & 117 & 20.067670 & 58.286230 & 2221576.9 & 6099482.2 & \\
\hline P5 & 118 & 20.067640 & 58.286250 & 2221573.6 & 6099484.3 & \\
\hline
\end{tabular}




$\begin{array}{lrrrrr}\text { P5 } & 119 & 20.067660 & 58.286260 & 2221575.8 & 6099485.3 \\ \text { P5 } & 120 & 20.067740 & 58.286180 & 2221584.7 & 6099477 \\ \text { P5 } & 121 & 20.067760 & 58.286220 & 2221586.9 & 6099481.2 \\ \text { P5 } & 122 & 20.067780 & 58.286230 & 2221589.1 & 6099482.2 \\ \text { P5 } & 123 & 20.067810 & 58.286210 & 2221592.4 & 6099480.1 \\ \text { P5 } & 124 & 20.067830 & 58.286210 & 2221594.6 & 6099480.1 \\ \text { P5 } & 125 & 20.067970 & 58.286330 & 2221610.1 & 6099492.7 \\ \text { P5 } & 126 & 20.067960 & 58.286310 & 2221609 & 6099490.6 \\ \text { P5 } & 127 & 20.067940 & 58.286380 & 2221606.8 & 6099497.9 \\ \text { P5 } & 128 & 20.067960 & 58.286400 & 2221609 & 6099500 \\ \text { P5 } & 129 & 20.067960 & 58.286420 & 2221609.5 & 6099502.1 \\ \text { P5 } & 130 & 20.067960 & 58.286420 & 2221609 & 6099502.1 \\ \text { P5 } & 131 & 20.067990 & 58.286480 & 2221612.3 & 6099508.4 \\ \text { P5 } & 132 & 20.067980 & 58.286500 & 2221611.2 & 6099510.5 \\ \text { P5 } & 133 & 20.067950 & 58.286520 & 2221607.9 & 6099512.6 \\ \text { P5 } & 134 & 20.067940 & 58.286540 & 2221606.8 & 6099514.6 \\ \text { P5 } & 135 & 20.067880 & 58.286580 & 2221600.2 & 6099518.8 \\ \text { P5 } & 136 & 20.067740 & 58.286510 & 2221584.7 & 6099511.5 \\ \text { P5 } & 137 & 20.067700 & 58.286490 & 2221580.2 & 6099509.4 \\ \text { P5 } & 138 & 20.067700 & 58.286480 & 2221580.2 & 6099508.4 \\ \text { P5 } & 101 & 20.067933 & 58.286317 & 2221606.1 & 6099491.3 \\ \text { P5 } & 139 & 20.067710 & 58.286470 & 2221581.4 & 6099507.3 \\ \text { P5 } & 140 & 20.067730 & 58.286480 & 2221583.6 & 6099508.4 \\ \text { P5 } & 141 & 20.067760 & 58.286460 & 2221586.9 & 6099506.3 \\ \text { P5 } & 142 & 20.067690 & 58.286460 & 2221579.1 & 6099506.3 \\ \text { P5 } & 143 & 20.067690 & 58.286410 & 2221579.1 & 6099501 \\ \text { P5 } & 144 & 20.067700 & 58.286420 & 2221580.2 & 6099502.1 \\ \text { P5 } & 145 & 20.067710 & 58.286420 & 2221581.4 & 6099502.1 \\ \text { P5 } & 146 & 20.067720 & 58.286360 & 2221582.5 & 6099495.8 \\ \text { P5 } & 147 & 20.067740 & 58.286350 & 2221584.7 & 6099494.8 \\ \text { P5 } & 148 & 20.067760 & 58.286330 & 2221586.9 & 6099492.7 \\ \text { P6 } & 20.067667 & 58.286233 & 2221576.6 & 6099482.6 \\ \text { P5 } & 20.067783 & 58.286283 & 2221589.5 & 6099487.8 \\ \text { P5 } & 20.067933 & 58.286350 & 2221606.1 & 6099494.8 \\ \text { P5 } & 138.286317 & 2221576.6 & 6099491.3\end{array}$




\begin{tabular}{lrrrrr} 
P5 & 94 & 20.067817 & 58.286217 & 2221593.2 & 6099480.8 \\
P5 & 88 & 20.067583 & 58.286167 & 2221567.3 & 6099475.6 \\
P5 & 85 & 20.067683 & 58.286267 & 2221578.4 & 6099486 \\
P5 & 107 & 20.067550 & 58.286533 & 2221563.6 & 6099513.9 \\
P5 & 108 & 20.067700 & 58.286433 & 2221580.2 & 6099503.5 \\
P5 & 92 & 20.067733 & 58.286133 & 2221583.9 & 6099472.1 \\
P5 & 105 & 20.067817 & 58.286400 & 2221593.2 & 6099500 \\
P5 & 87 & 20.067600 & 58.286200 & 2221569.2 & 6099479.1 \\
P5 & 96 & 20.067850 & 58.286133 & 2221596.8 & 6099472.1 \\
P5 & 103 & 20.067800 & 58.286350 & 2221591.3 & 6099494.8 \\
P5 & 83 & 20.067750 & 58.286317 & 2221585.8 & 6099491.3 \\
P5 & 97 & 20.067850 & 58.286167 & 2221596.8 & 6099475.6 \\
P5 & 89 & 20.067583 & 58.286150 & 2221567.3 & 6099473.8 \\
P5 & 104 & 20.067833 & 58.286400 & 2221595 & 6099500 \\
P5 & 82 & 20.067750 & 58.286283 & 2221585.8 & 6099487.8 \\
P5 & 106 & 20.067883 & 58.286400 & 2221600.5 & 6099500 \\
& & & & & \\
P6 & 181 & 20.069070 & 58.287380 & 2221731.9 & 6099602.6 \\
P6 & 177 & 20.069070 & 58.287310 & 2221731.9 & 6099595.2 \\
P6 & 152 & 20.068850 & 58.287160 & 2221707.6 & 6099579.5 \\
P6 & 154 & 20.068760 & 58.287200 & 2221697.6 & 6099583.7 \\
P6 & 155 & 20.068780 & 58.287190 & 2221699.8 & 6099582.7 \\
P6 & 156 & 20.068780 & 58.287150 & 2221699.8 & 6099578.5 \\
P6 & 159 & 20.068920 & 58.287090 & 2221715.3 & 6099572.2 \\
P6 & 160 & 20.068930 & 58.287070 & 2221716.4 & 6099570.1 \\
P6 & 161 & 20.068940 & 58.287070 & 2221717.5 & 6099570.1 \\
P6 & 164 & 20.069070 & 58.287040 & 2221731.9 & 6099567 \\
P6 & 165 & 20.069100 & 58.286960 & 2221735.2 & 6099558.6 \\
P6 & 166 & 20.069110 & 58.287040 & 2221736.3 & 6099567 \\
P6 & 167 & 20.069130 & 58.287030 & 2221738.6 & 6099565.9 \\
P6 & 175 & 20.069080 & 58.287110 & 2221733 & 6099574.3 \\
P6 & 20.069080 & 58.287270 & 2221733 & 6099591 \\
\hline
\end{tabular}




\begin{tabular}{|c|c|c|c|c|c|c|}
\hline P6 & 182 & 20.069050 & 58.287430 & 2221729.7 & 6099607.8 & \\
\hline P6 & 183 & 20.068960 & 58.287430 & 2221719.7 & 6099607.8 & \\
\hline P6 & 184 & 20.068970 & 58.287410 & 2221720.8 & 6099605.7 & \\
\hline P6 & 190 & 20.068840 & 58.287310 & 2221706.4 & 6099595.2 & \\
\hline P6 & 191 & 20.068860 & 58.287300 & 2221708.7 & 6099594.2 & \\
\hline P6 & 193 & 20.068800 & 58.287360 & 2221702 & 6099600.5 & \\
\hline P6 & 198 & 20.068760 & 58.287400 & 2221697.6 & 6099604.6 & \\
\hline P6 & 201 & 20.068850 & 58.287220 & 2221707.6 & 6099585.8 & \\
\hline P6 & 196 & 20.068717 & 58.287367 & 2221692.8 & 6099601.2 & \\
\hline P6 & 192 & 20.068817 & 58.287350 & 2221703.9 & 6099599.4 & NW corner,no coord \\
\hline P6 & 157 & 20.068850 & 58.287117 & 2221707.6 & 6099575 & \\
\hline P6 & 199 & 20.068750 & 58.287450 & 2221696.5 & 6099609.9 & \\
\hline P6 & 162 & 20.069017 & 58.287033 & 2221726 & 6099566.3 & \\
\hline P6 & 172 & 20.069100 & 58.287183 & 2221735.2 & 6099582 & \\
\hline P6 & 151 & 20.068833 & 58.287133 & 2221705.7 & 6099576.7 & \\
\hline P6 & 170 & 20.069133 & 58.287067 & 2221738.9 & 6099569.8 & \\
\hline P6 & 174 & 20.069100 & 58.287183 & 2221735.5 & 6099582 & \\
\hline P6 & 188 & 20.068867 & 58.287333 & 2221709.4 & 6099597.7 & \\
\hline P6 & 189 & 20.068833 & 58.287300 & 2221705.7 & 6099594.2 & \\
\hline P6 & 173 & 20.069033 & 58.287167 & 2221727.8 & 6099580.2 & \\
\hline P6 & 194 & 20.068767 & 58.287317 & 2221698.3 & 6099595.9 & \\
\hline P6 & 163 & 20.069067 & 58.287017 & 2221731.5 & 6099564.5 & \\
\hline P6 & 200 & 20.068683 & 58.287250 & 2221689.1 & 6099588.9 & \\
\hline P6 & 186 & 20.068983 & 58.287417 & 2221722.3 & 6099606.4 & \\
\hline P6 & 149 & 20.068867 & 58.287250 & 2221709.4 & 6099588.9 & \\
\hline P6 & 153 & 20.068767 & 58.287200 & 2221698.3 & 6099583.7 & \\
\hline P6 & 179 & 20.069100 & 58.287300 & 2221735.2 & 6099594.2 & \\
\hline P6 & 197 & 20.068733 & 58.287350 & 2221694.6 & 6099599.4 & \\
\hline P6 & 187 & 20.068933 & 58.287383 & 2221716.8 & 6099602.9 & \\
\hline P6 & 15 & 20.068883 & 58.287183 & 2221711.2 & 6099582 & \\
\hline P6 & 180 & 20.069117 & 58.287350 & 2221737.1 & 6099599.4 & \\
\hline P6 & 158 & 20.068900 & 58.287017 & 2221713.1 & 6099564.5 & \\
\hline
\end{tabular}




\section{Appendix B. Diggles F tests for Plots 1-6 for Total Palms Population.}

Non-theoretical lines above the theoretical signify repulsion, and those below the line signify aggregation.

\section{Diggles_F.Plot1}

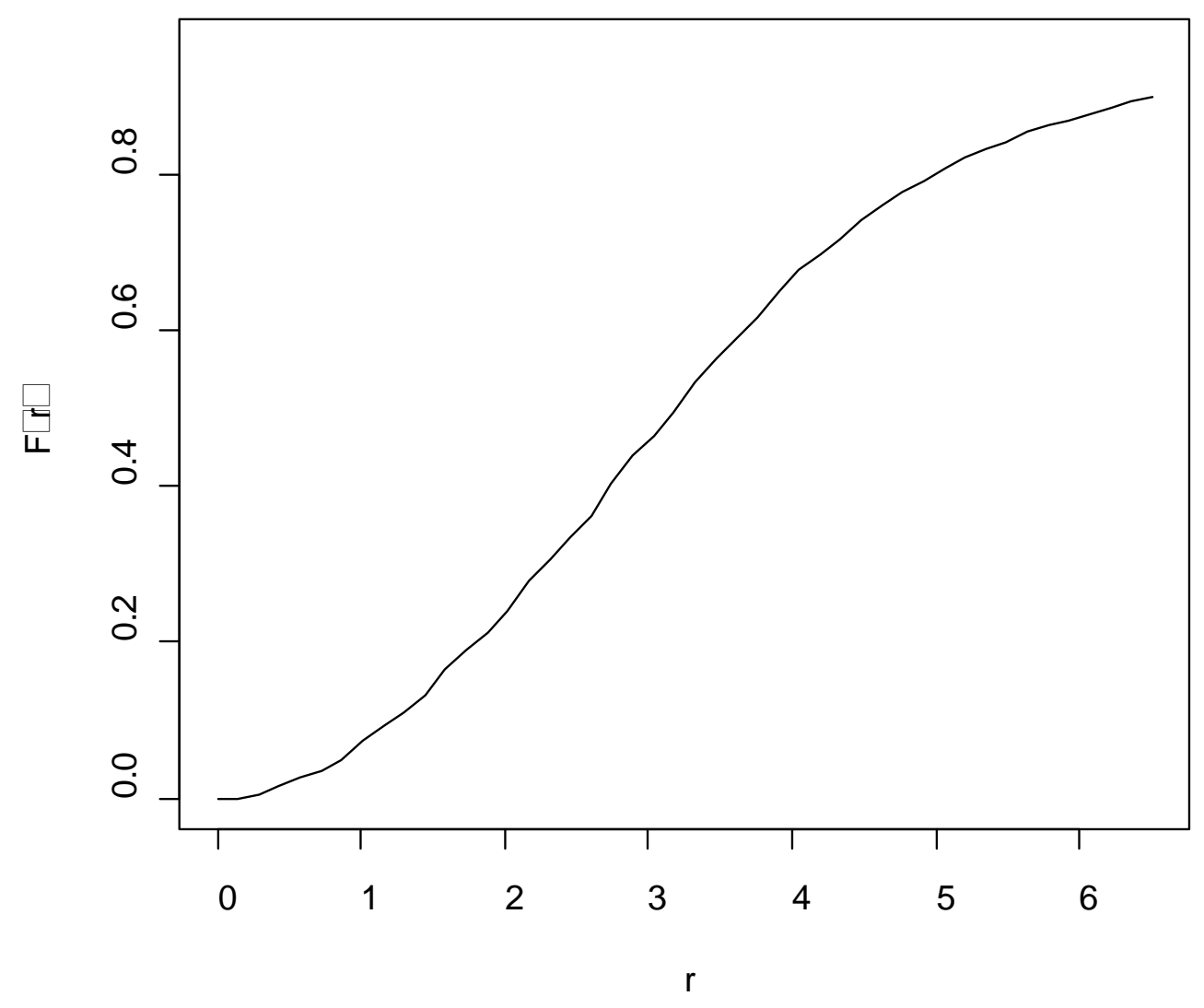

Figure B.1. Observed values do not deviate far from theoretical line. 


\section{Diggles_F.Plot2}

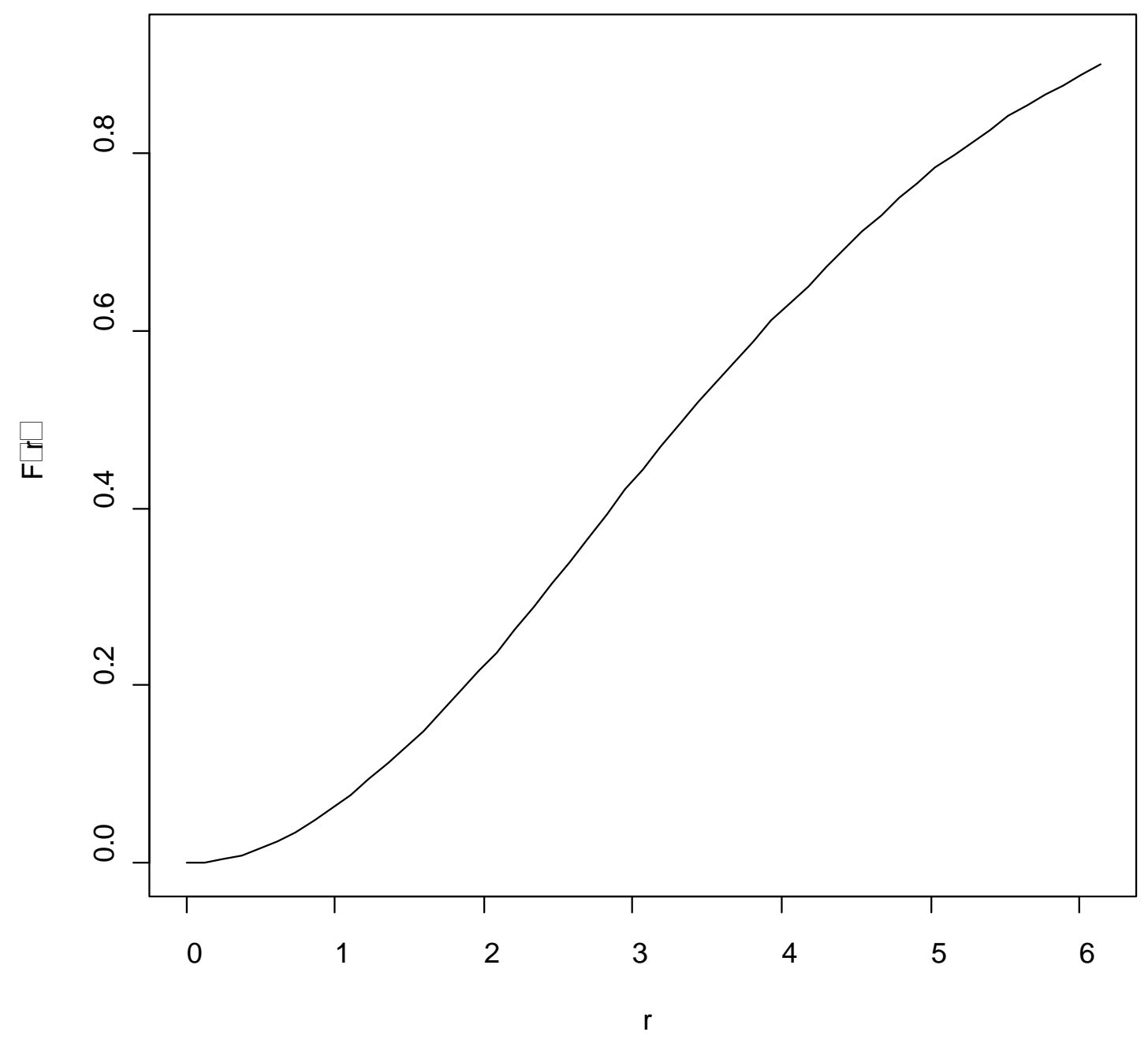

Figure B.2. Observed values does not deviate far from theoretical value, but do conform slightly below the theoretical line signifying the clustering at larger scales. 


\section{Diggles_F.Plot3}

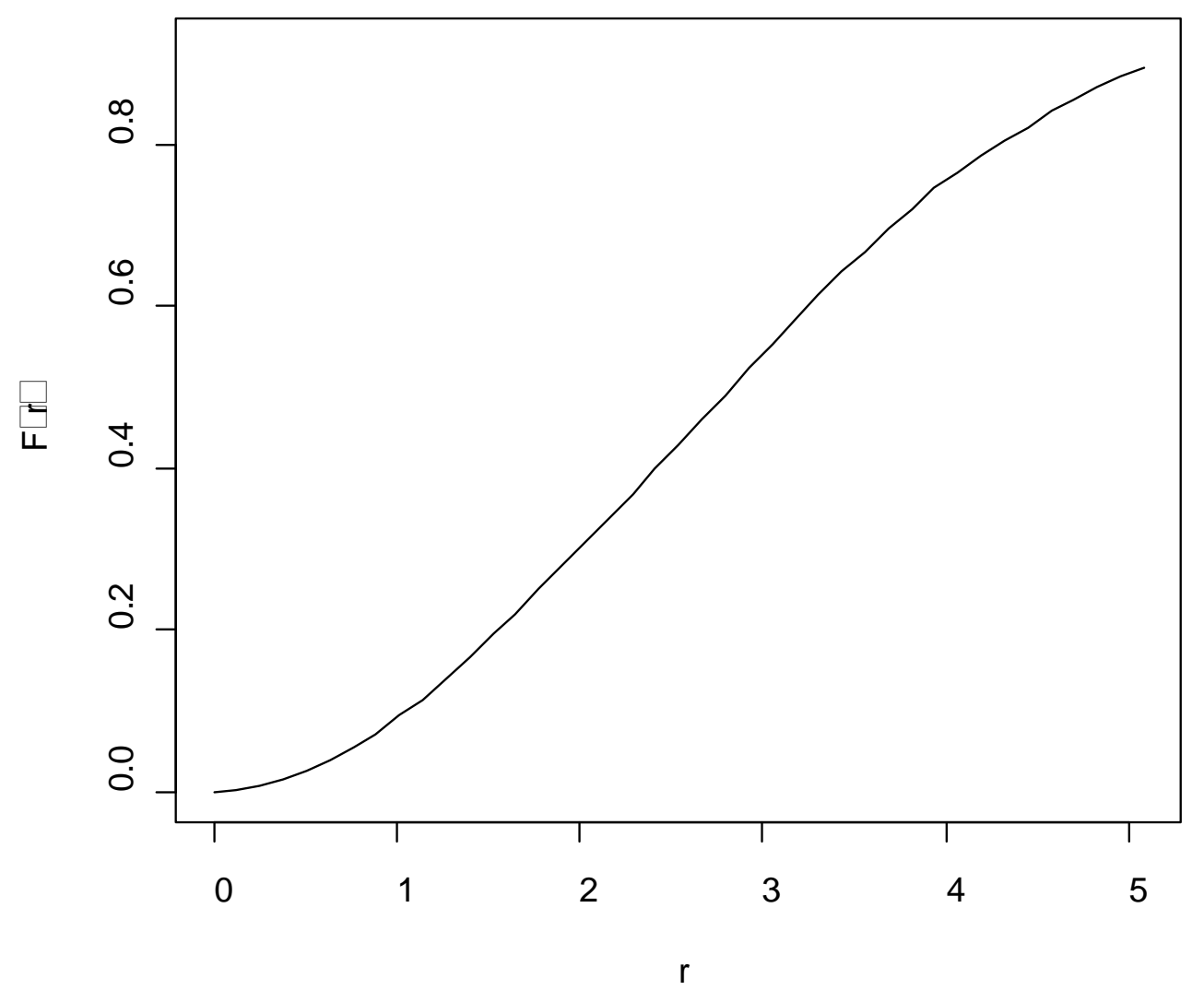

Figure B.3. Observed values does not deviate far from theoretical line, but do conform slightly below the theoretical line signifying the clustering. 


\section{Diggles_F.Plot4}

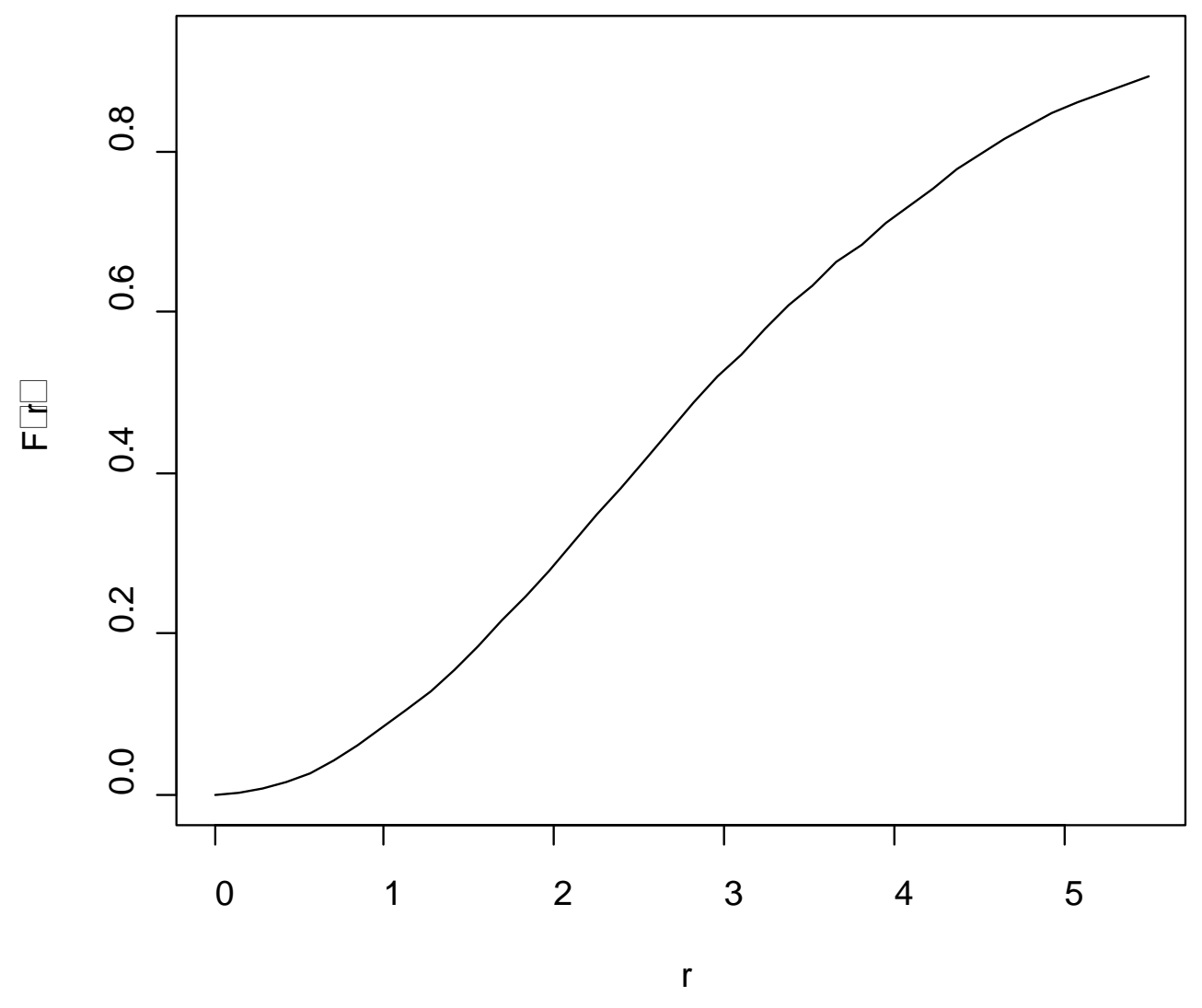

Figure B.4. Observed values does not deviate far from theoretical value, but do conform slightly below the theoretical line signifying the clustering. 


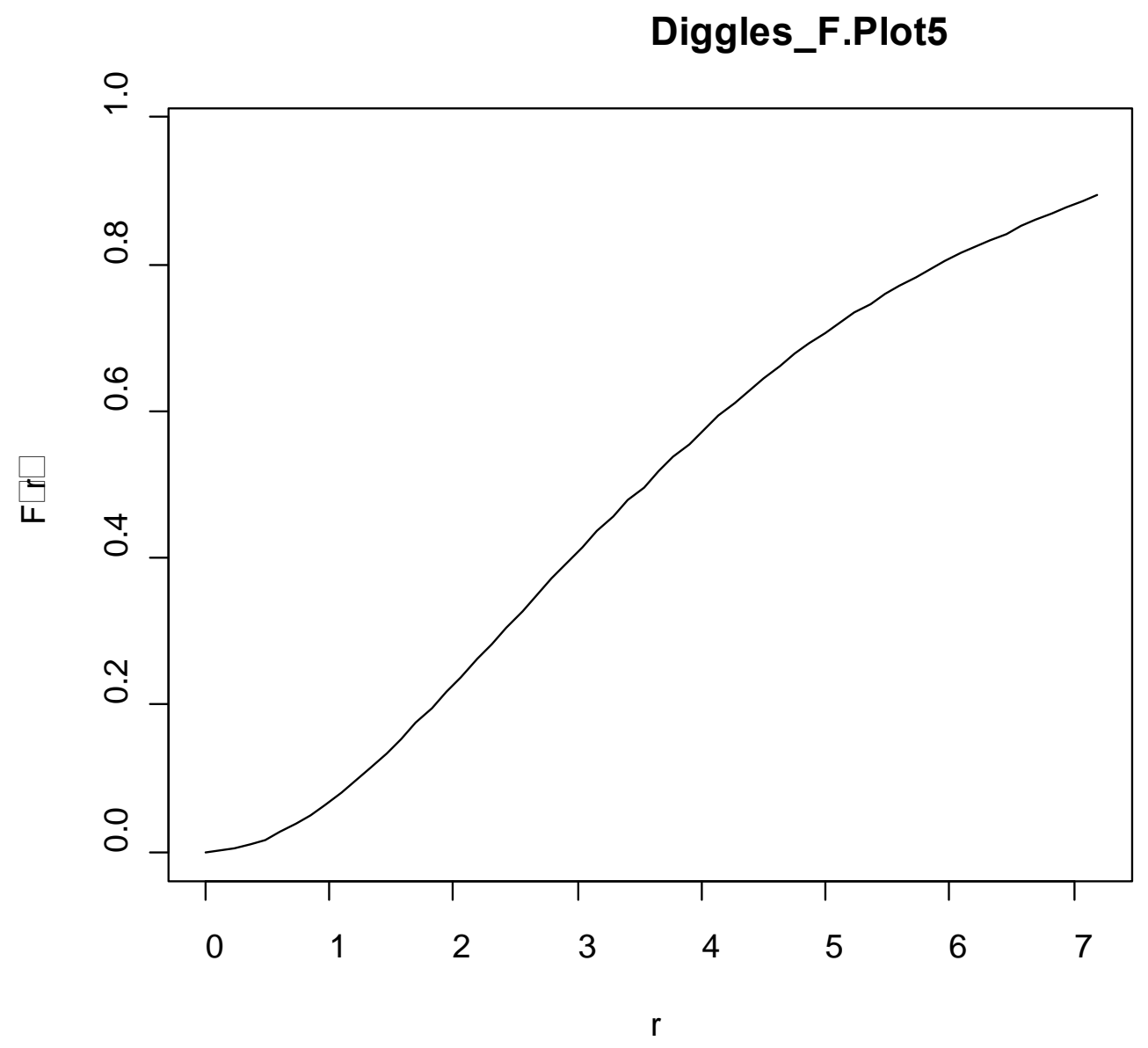

Figure B.5. Observed values deviate below the theoretical line at larger scales signifying the cluster. 


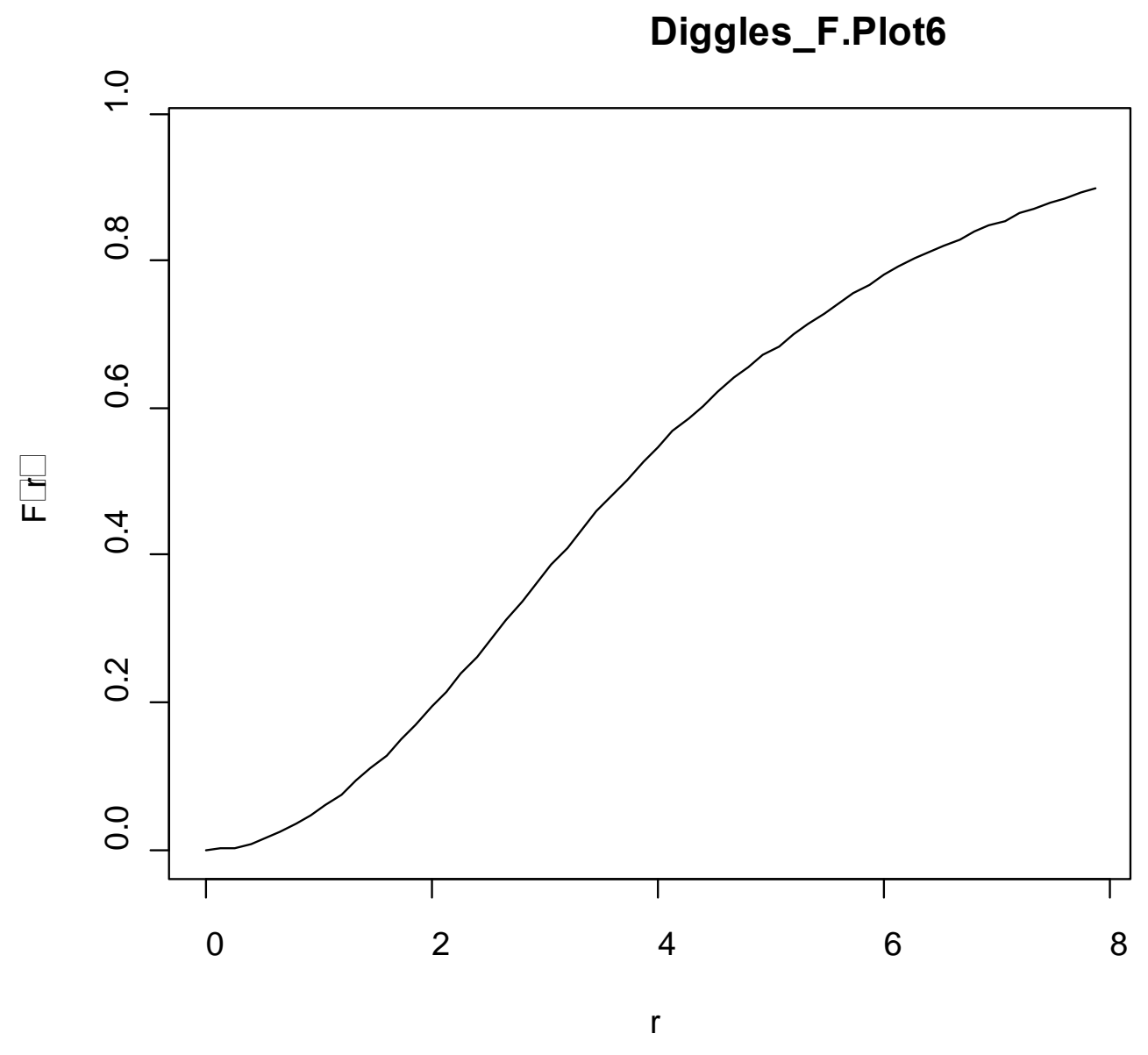

Figure B.6. Observed values deviate below the theoretical line at larger scales signifying the cluster. 
Appendix C. Spatial Symbol Diagrams with juveniles and adults for each 6 plots.

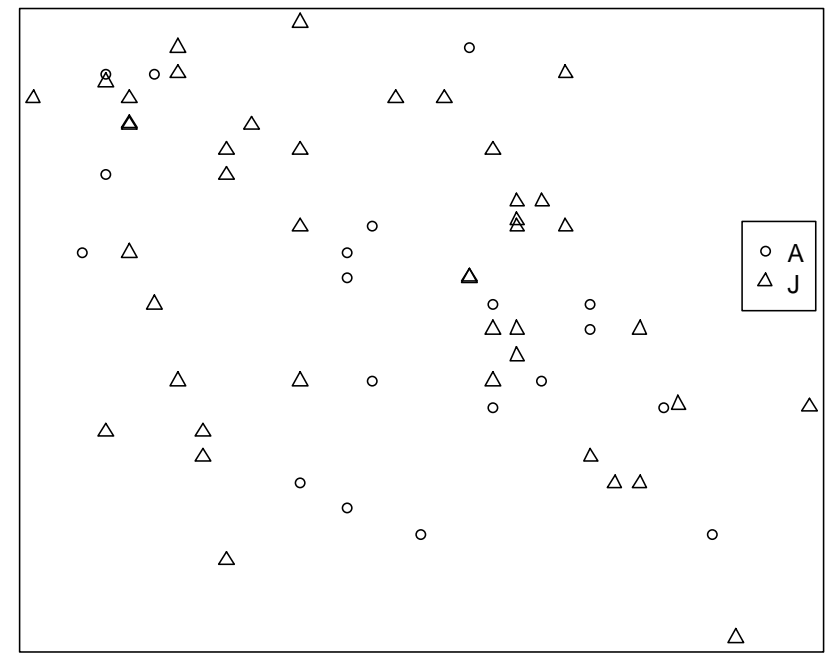

Figure C.1. Plot 1. Spatial Distribution of palms with stems $3.5 \mathrm{~m}$ height (adults $=$ A) and palms with stems $\geq 1$ meter and $<3.5 \mathrm{~m}$ (juveniles $=\mathrm{J}$ ).

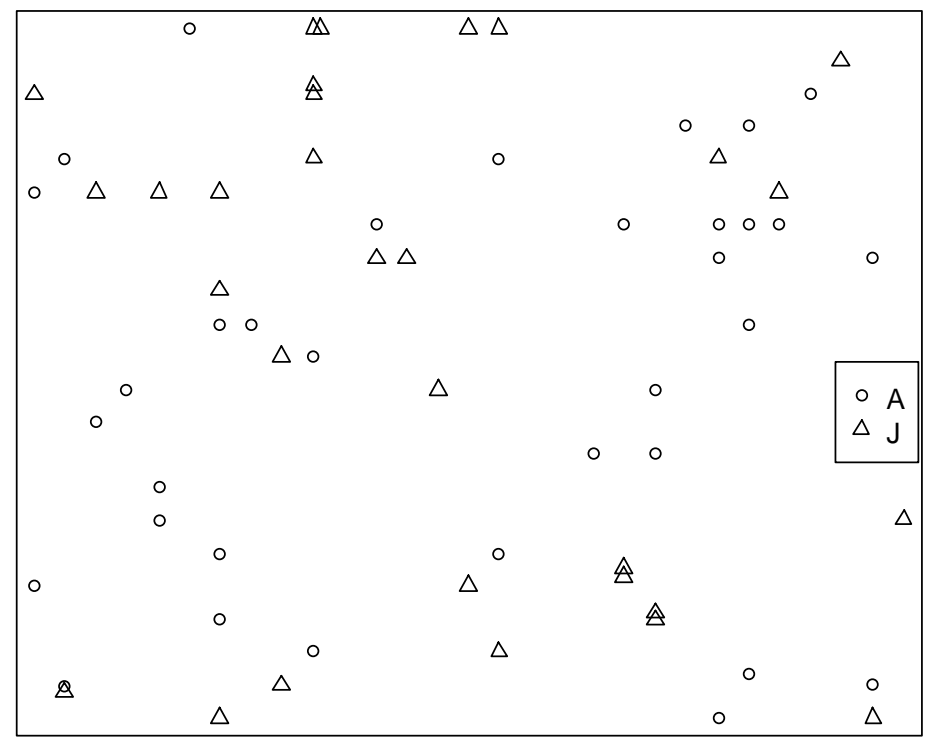

Figure C.2. Plot 3. Spatial Distribution of palms with stems $3.5 \mathrm{~m}$ height (adults $=\mathrm{A}$ ) and palms with stems $\geq 1$ meter and $<3.5 \mathrm{~m}$ (juveniles $=\mathrm{J}$ ). 


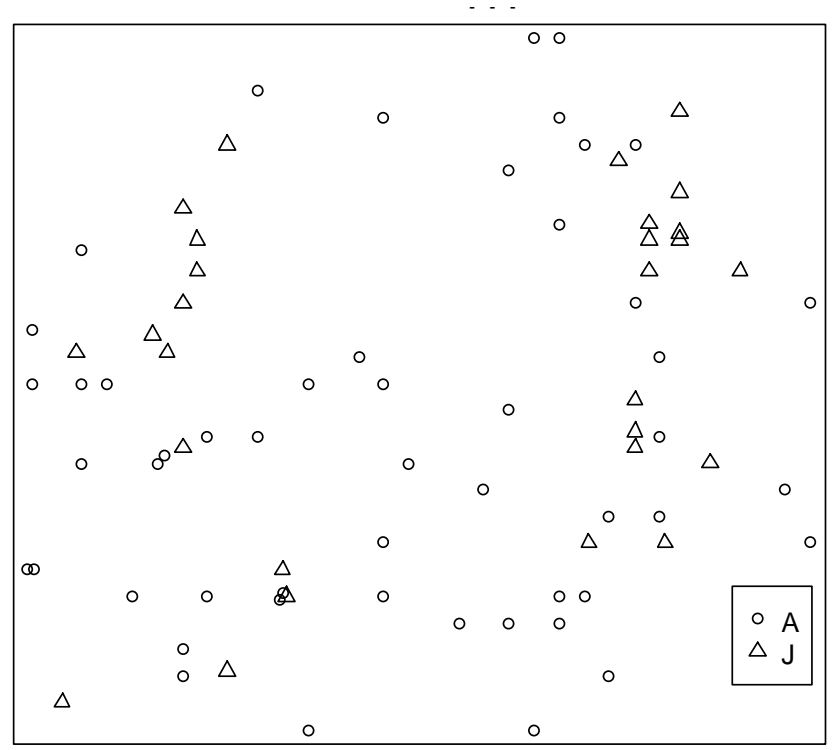

Figure C.3. Plot 4. Spatial Distribution of palms with stems $3.5 \mathrm{~m}$ height (adults $=\mathrm{A}$ ) and palms with stems $\geq 1$ meter and $<3.5 \mathrm{~m}$ (juveniles $=\mathrm{J}$ ).

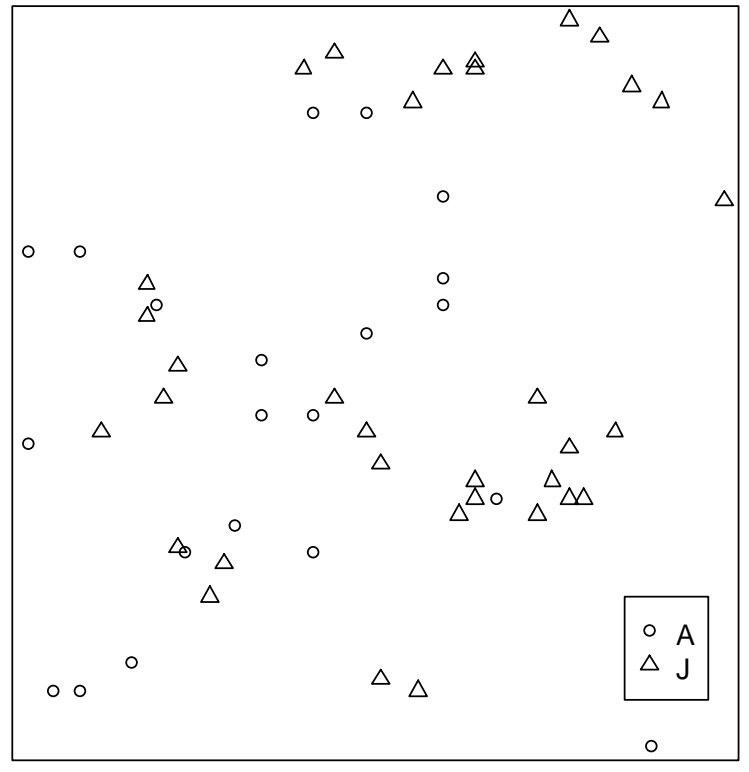

Figure C.4. Plot 5. Spatial Distribution of palms with stems $3.5 \mathrm{~m}$ height (adults $=\mathrm{A}$ ) and palms with stems $\geq 1$ meter and $<3.5 \mathrm{~m}$ (juveniles $=\mathrm{J}$ ). 


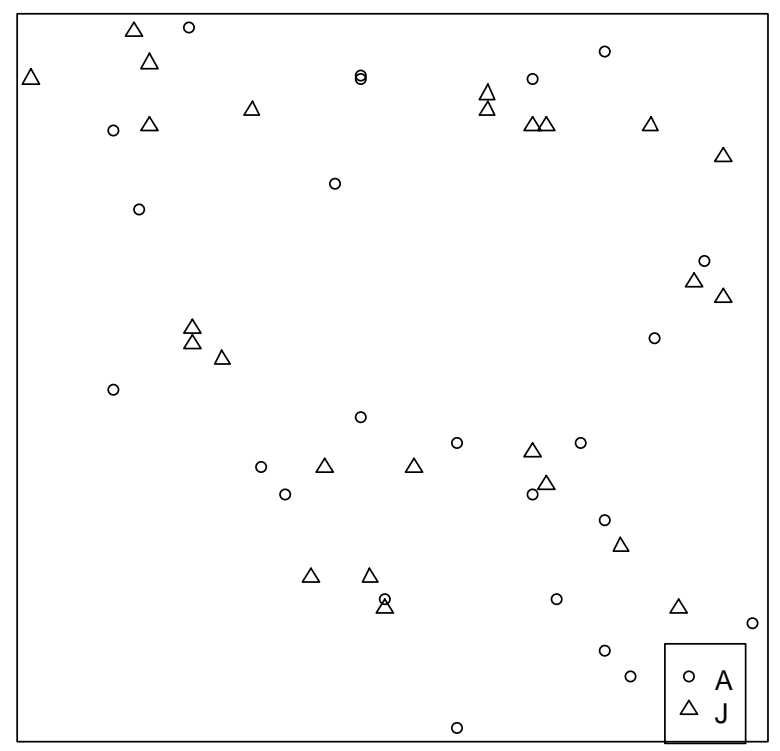

Figure C.5. Plot 6. Spatial Distribution of palms with stems $3.5 \mathrm{~m}$ height (adults $=\mathrm{A}$ ) and palms with stems $\geq 1$ meter and $<3.5 \mathrm{~m}$ (juveniles $=\mathrm{J}$ ). 
Appendix D. Diameter Distributions for each of the 6 plots.

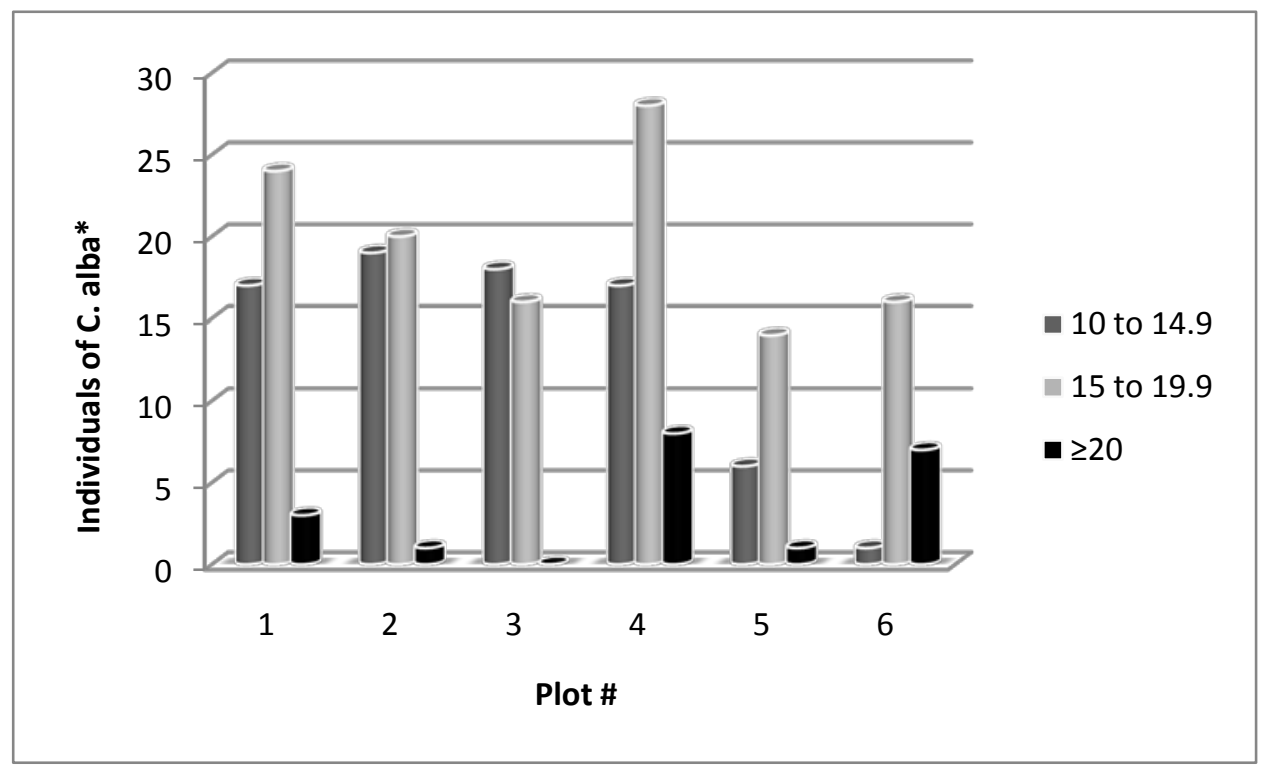

Figure D.1. Diameter distributions in $\mathrm{cm}$. 


\section{Appendix E. Permission and Use}

Hi Michelle,

Yes, you have full permission to use the photos of Bahia Negra

attached to this email in your thesis.

Joan Ngo

On Sat, Mar 5, 2011 at 9:03 PM, Michelle Cisz <cisz.michelle@gmail.com>wrote:

Permission from an email for pictures as cited from Joan Ngo.

Figure 3.2 was adapted from Google Earth. Please see the following website for permission of use:

http://www.google.com/permissions/geoguidelines.html 